ORP-56288

Revision 0

\title{
Report - Melter Testing of New High Bismuth HLW Formulations VSL-13R2770-1
}

Prepared for the U.S. Department of Energy

Assistant Secretary for Environmental Management

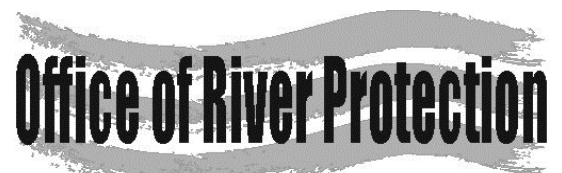

P.O. Box 450

Richland, Washington 99352 
ORP-56288

Revision 0

\section{Report - Melter Testing of New High Bismuth HLW Formulations VSL-13R2770-1}

A. A. Kruger

Department of Energy - Office of River Protection

I. L. Pegg

The Catholic University of America

W. K. Kot

The Catholic University of America
H. Gan

The Catholic University of America

K. S. Matlack

The Catholic University of America

Date Published

June 2013

Prepared for the U.S. Department of Energy

Assistant Secretary for Environmental Management

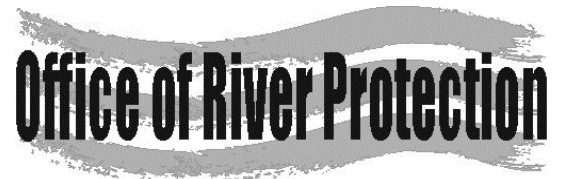

P.O. Box 450

Richland, Washington 99352

\section{APPROVED}

By Shauna Adams at 9:17 am, Nov 13, 2013

Release Approval

Date 
ORP-56288

Revision 0

TRADEMARK DISCLAIMER

Reference herein to any specific commercial product, process, or service by tradename, trademark, manufacturer, or otherwise, does not necessarily constitute or imply its endorsement, recommendation, or favoring by the United States Government or any agency thereof or its contractors or subcontractors.

This report has been reproduced from the best available copy.

Printed in the United States of America 


\title{
Final Report
}

Melter Testing of New High Bismuth HLW Formulations

\author{
prepared by
}

Keith S. Matlack, Wing Kot, Hao Gan, and Ian L. Pegg

Vitreous State Laboratory

The Catholic University of America

Washington, DC 20064

and

Innocent Joseph

EnergySolutions Federal EPC, Inc.

Columbia, MD 21046

for

Department of Energy

Office of River Protection

January 31, 2013

Rev. 0, 3/25/13 
The Catholic University of America Vitreous State Laboratory
Melter Testing of New High Bismuth HLW Formulations Final Report, VSL-13R2770-1, Rev, 0

Document Title: $\quad$ Melter Testing of New High Bismuth HLW Formulations

\section{Document Number and Revision:}

Issue Date:

Performing Organization: Vitreous State Laboratory, The Catholic University of America

Test Plan:
Melter Testing of New High Bismuth HLW Formulations, VSL-12T2770-1, Rev. 0

This report describes the results of testing specified by the above Test Plan. The work was performed in compliance with the quality assurance requirements specified in the Test Plan. Results required by the Test Plan are reported. The test results and this report have been reviewed for correctness, technical adequacy, completeness, and accuracy.

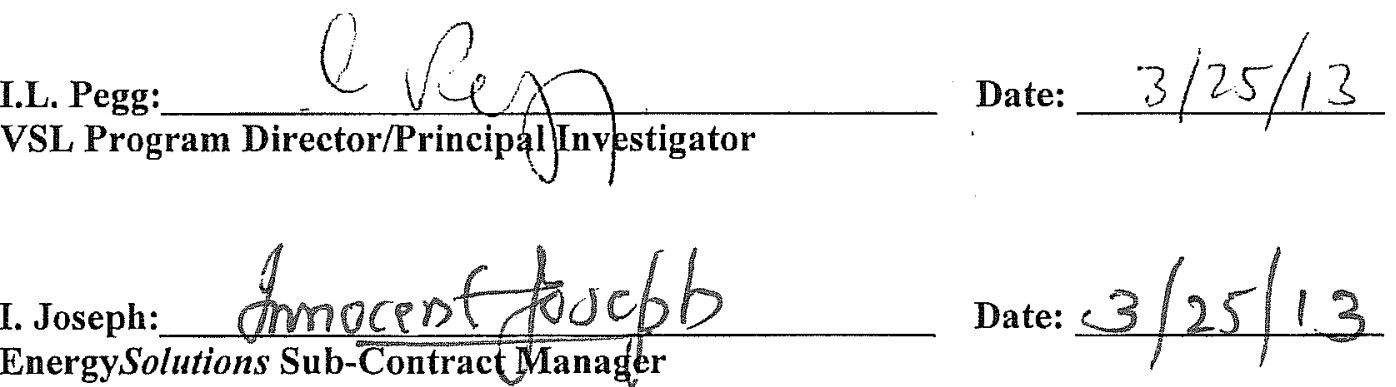


ORP-56288 Rev. 0

The Catholic University of America

Vitreous State Laboratory
Melter Testing of New High Bismuth HLW Formulations

Final Report, VSL-13R2770-1, Rev. 0

\section{TABLE OF CONTENTS}

LIST OF TABLES. 4

LIST OF FIGURES .5

LIST OF ABBREVIATIONS .7

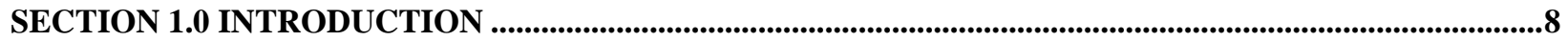

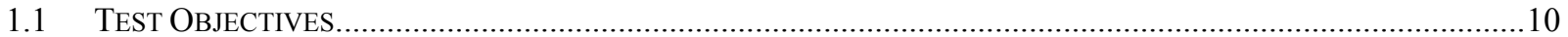

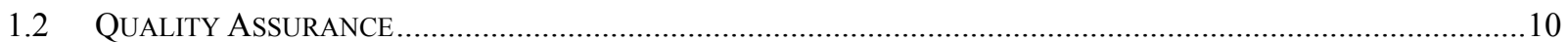

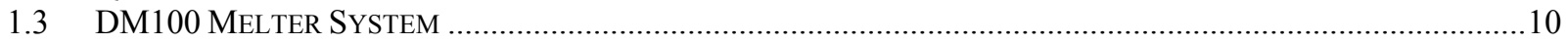

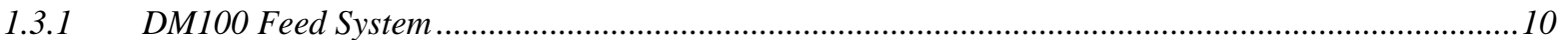

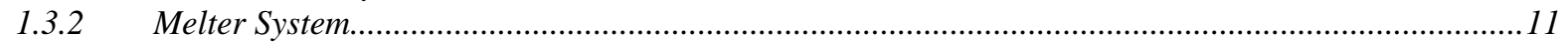

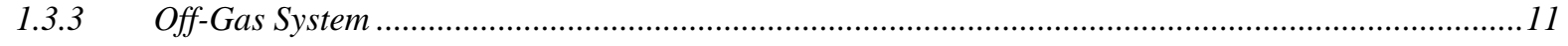

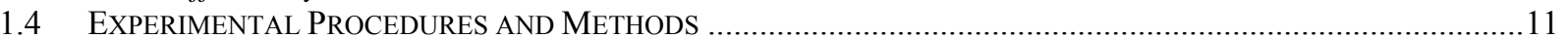

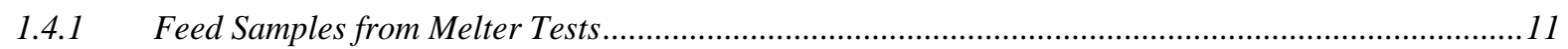

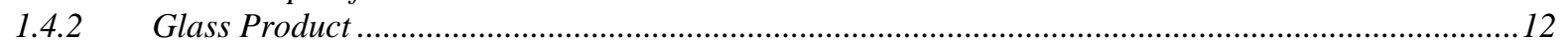

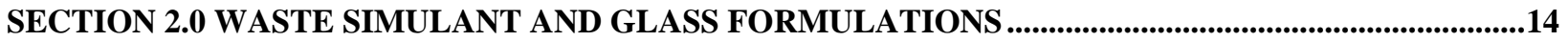

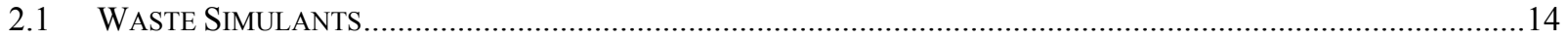

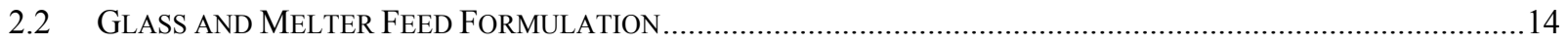

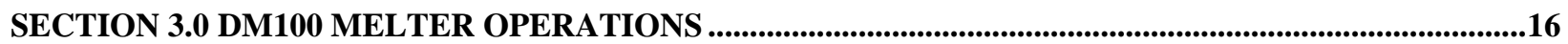

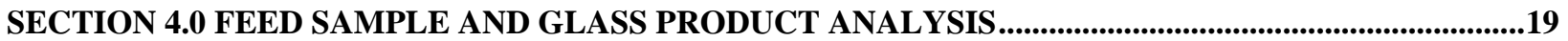

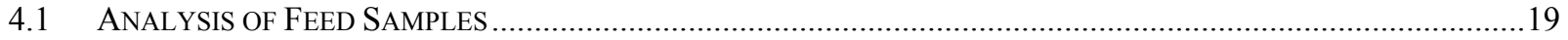

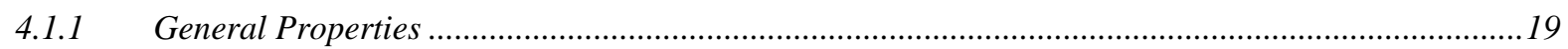

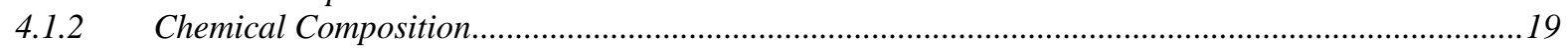

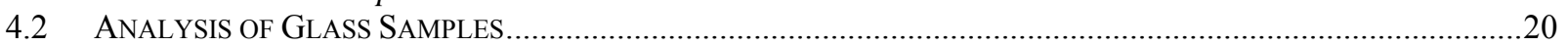

4.2.1 Compositional Analysis of Discharge and Dip Sample Glasses......................................................20

4.2.2 Chemical Durability of Discharge Glasses ..........................................................................................21

4.2.3 Canister Centerline Cooling (CCC) of Glass Samples ........................................................................21

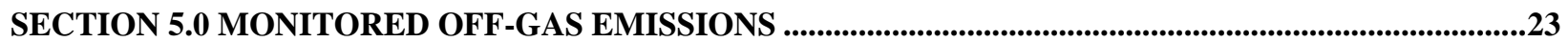

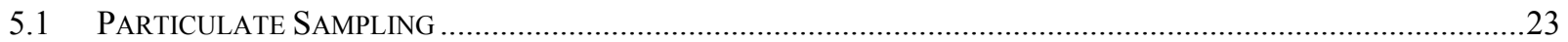

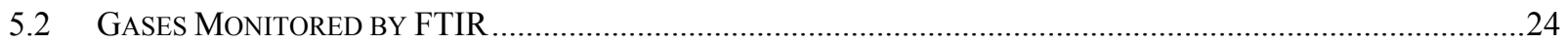

SECTION 6.0 SUMMARY AND CONCLUSIONS .....................................................................................................25

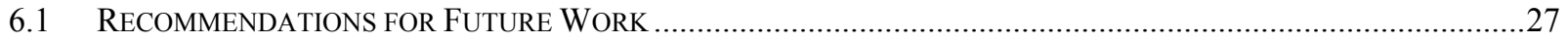

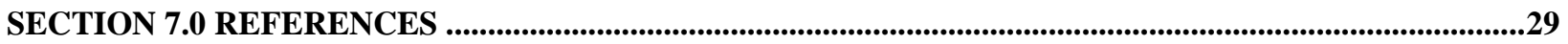




\section{List of Tables}

$\underline{\text { Page \# }}$

Table 2.1 Oxide Compositions of Limiting Waste Streams

Table 2.2 Compositions of the Bi-Limited Waste (Oxide Basis) and the HLW Waste

Simulant to Produce $100 \mathrm{~kg}$ of Waste Oxides (20 wt\% suspended solids)

Table 2.3 Compositions and Properties of Bismuth Limited Waste and Glass

Formulation, HLW-Bi-F3 at 50\% Waste Loading Used in Melter Tests (wt\%)

Table 2.4 Compositions and Properties of Bismuth Limited Waste and Glass

Formulation, HLW-Bi-F9 at 50\% Waste Loading Used in Melter Tests ( $\mathrm{wt} \%$ )

Table 2.5 Composition of Melter Feed to Produce $100 \mathrm{~kg}$ of Target Glass HLW-Bi-F3

(Glass Yield $=500 \mathrm{~g} / \mathrm{L}$ Feed) from the Bi-Limited Waste Simulant

Table 2.6 Composition of Melter Feed to Produce $100 \mathrm{~kg}$ of Target Glass HLW-Bi-F9

(Glass Yield $=500 \mathrm{~g} / \mathrm{L}$ Feed) from the Bi-Limited Waste Simulant

Table 3.1 Summary of Results from DM100 Tests with High Bismuth Waste and

HLW-Bi-F3 Glass Composition

Table 3.2 Summary of Results from DM100 Tests with High Bismuth Waste and HLW-Bi-F9 Glass Composition

Table 3.3 Steady-State Production Rates Achieved on the DM100 Melter with High

Bismuth Waste; $500 \mathrm{~g}$ glass/liter and 50\% Waste Oxide Loading

Table 3.4 Summary of Measured DM100 Parameters while Processing the HLW-Bi-F3 Glass Composition

Table 3.5 Summary of Measured DM100 Parameters while Processing the HLW-Bi-F9 Glass Composition

Table 4.1

Characteristics of Melter Feed Samples with High Bismuth Waste

XRF Analyzed Compositions of Vitrified Melter Feed Samples (wt\%)

Listing of Glass Discharged and Masses

XRF Analyzed Composition for Glass Discharged During DM100 Melter

Tests (wt\%)

Table 4.4

XRF Analyzed Composition for Dip Samples Taken Before and After DM100 Melter Tests (wt\%)

Table 4.6

PCT Results for Melter and Crucible Glasses (ASTM C1285, 7-days at $90^{\circ} \mathrm{C}$, Stainless Steel Vessel; S/V=2000 m-1)

Table 4.7

TCLP Results for Melter and Crucible

Table 5.1

Results from DM100 Off-Gas Emission Samples

Concentrations (ppmv) of Selected Species in DM100 Exhaust Measured by

FTIR Spectroscopy
$\mathrm{T}-1$

$\mathrm{T}-2$

$\mathrm{T}-3$

$\mathrm{T}-4$

T-5

T-6

$\mathrm{T}-7$

T-8

T-9

T-10

T-11

T-12

T-13

T-15

T-18

T-24

T-25

T-26

T-27

T-29 


\section{List of Figures}

$\underline{\text { Page \# }}$

Figure 1.1 Schematic diagram of DuraMelter 100 vitrification system

F-1

Figure 1.2.a

Schematic diagram showing cross-section through the DM100-BL-melter.

Plan view showing locations of lid ports

F-2

F-3

F-4

Schematic diagram showing cross-section through the DM100-BL melter

Glass production rates (hourly moving averages and cumulative) for DM100

test with HLW-Bi-F3 glass composition

F-5

F-6

test with HLW-Bi-F9 glass composition

Figure 3.2.a Glass temperatures (hourly averages) during DM100 test with HLW-Bi-F3 glass composition

F-7

F-8

glass composition

Plenum temperatures (hourly averages) during DM100 test with HLW-Bi-F3 glass composition

F-9

Plenum temperatures (hourly averages) during DM100 test with HLW-Bi-F9 glass composition

F-10

Electrode temperatures and power (hourly averages) during DM100 test with HLW-Bi-F3 glass composition

Figure 3.4.b Electrode temperatures and power (hourly averages) during DM100 test with HLW-Bi-F9 glass composition

Figure 3.5.a Melt pool resistance and total electrode power during DM100 test with HLW-Bi-F3 glass composition

Figure 3.5.b Melt pool resistance and total electrode power during DM100 test with HLW-Bi-F9 glass composition

Figure 3.6.a

Figure 3.6.b

Figure 4.1

Figure 4.2

Figure 4.3

Figure 4.4

Figure 4.5

Figure 4.6

Figure 4.7

Figure 4.8

Melt pool bubbling during DM100 test with HLW-Bi-F3 glass composition

Melt pool bubbling during DM100 test with HLW-Bi-F9 glass composition

DM100 product and target glass compositions determined by XRF

DM100 product and target glass compositions determined by XRF

DM100 product and target glass compositions determined by XRF

DM100 product and target glass compositions determined by XRF

DM100 product and target glass compositions determined by XRF

DM100 product and target glass compositions determined by XRF

DM100 product and target glass compositions determined by XRF

Typical areas in bulk of LBL-G-8A (HLW-Bi-F3 composition) at low (top) and high (bottom) magnification

Figure 4.9a Region of incipient lithiophosphate growth in LBL-G-71A (HLW-Bi-F9 composition). Vesicles are circular dark regions, frequently surrounded by tiny crystals of other phases

Figure 4.9.b Large area view of LBL-G-71A (HLW-Bi-F9 composition) near bottom

of crucible (to the right) showing settling of large spinels

F-11

F-12

F-13

F-14

F-15

F-16

F-17

F-18

F-19

F-20

F-21

F-22

F-23

F-24

F-25

F-26

FTIR monitored nitrogen oxide emissions during tests processing the HLW-Bi-F3 composition

F-27

F-28

composition

F-29

HLW-Bi-F3 composition

F-30 
ORP-56288 Rev. 0

The Catholic University of America

Melter Testing of New High Bismuth HLW Formulations

Vitreous State Laboratory

Final Report, VSL-13R2770-1, Rev. 0

Figure 5.5 FTIR monitored water emissions during tests processing the HLW-Bi-F9 composition F-31

Figure 5.6 FTIR monitored hydrogen fluoride emissions during tests processing the HLW-Bi-F9 composition

F-32 


\section{List of Abbreviations}

\begin{tabular}{ll} 
ASME & American Society of Mechanical Engineers \\
ANL-LRM & Argonne National Laboratory - Low Activity Waste Reference Material \\
BNI & Bechtel National, Inc. \\
CCC & Canister Center Line Cooling \\
DCP-AES & Direct Current Plasma Atomic Emission Spectroscopy \\
DF & Decontamination Factor \\
DM & DuraMelter \\
DOE & Department of Energy \\
DWPF & Defense Waste Processing Facility \\
EA & Environmental Assessment \\
EDS & Energy Dispersive X-Ray Spectroscopy \\
FTIR & Fourier Transform Infrared Spectroscopy \\
IC & Ion Chromatography \\
HEPA & High-Efficiency Particulate Air Filter \\
HLW & High Level Waste \\
IHLW & Immobilized High Level Waste \\
LAW & Low Activity Waste \\
NIST & National Institute of Standards and Technology \\
ORP & Office of River Protection \\
PCT & Product Consistency Test \\
NQA & Nuclear Quality Assurance \\
QAPP & Quality Assurance Project Plan \\
QARD & Quality Assurance Requirements and Description \\
SEM & Scanning Electron Microscopy \\
SOP & Standard Operating Procedure \\
TCLP & Toxicity Characteristic Leaching Procedure \\
UTS & Universal Treatment Standards \\
VSL & Vitreous State Laboratory \\
WTP & Hanford Tank Waste Treatment and Immobilization Plant \\
XRF & X-Ray Fluorescence Spectroscopy \\
& \\
\hline
\end{tabular}




\section{SECTION 1.0 INTRODUCTION}

In previous work on Hanford High Level Waste (HLW) streams containing high concentrations of bismuth specified by the Office of River Protection (ORP), fully compliant, high waste loading compositions were developed and subjected to melter testing on the DM100 vitrification system [1]. However, during heat treatment according to the Hanford Tank Waste Treatment and Immobilization Plant (WTP) HLW canister centerline cooling (CCC) curves, crucible melts of the high-bismuth glasses were observed to foam [1]. Clearly, such an occurrence during cooling of actual HLW canisters would be highly undesirable. This result was confirmed on larger-scale testing under more prototypical conditions as the bismuth concentration increased over the course of testing [2]. Testing was conducted on the DM1200 HLW Pilot Melter with a composition that was previously tested on the DM100 melter [1] and previously shown to foam during crucible-scale CCC heat treatment. The DM1200 tests evaluated foaming of glasses over a range of bismuth concentrations; the glass product was poured into temperature-controlled, 55-gallon drums with diameter that is close to that of the full-scale WTP HLW canisters in order to simulate full-scale CCC heat treatment. Crucible-scale tests were conducted with the high bismuth waste to investigate the causes of the observed foaming behavior and to remediate that behavior through glass formulation changes [2]. That work resulted in modified glass formulations that retained high waste loadings with significantly reduced tendency to foam during cooling. The focus of the present work was to test these new glass formulations for the high bismuth waste on the DM100 melter system to determine their processing characteristics, confirm product glass properties, and to assess their tendency to foam while cooling. This work builds on previous work performed at the Vitreous State Laboratory (VSL) for ORP on the same waste composition [1]. The work is described in a Test Plan [3] that is responsive to an ORP-supplied statement of work [4].

The HLW waste processing rate at the WTP depends on the glass production rate and waste loading in the glass, both of which have been the focus of on-going work for ORP by VSL/EnergySolutions. That work has demonstrated substantial improvements in waste loadings and glass production rates for a number of HLW compositions and has the potential for further improvements when applied across the spectrum of Hanford HLW compositions. The WTP HLW melter design, unlike earlier DOE melter designs, incorporates an active glass bubbler system. The bubblers create active glass pool convection and thereby improve heat transfer and glass melting rate. The WTP HLW melter has a glass surface area of $3.75 \mathrm{~m}^{2}$ and depth of $\sim 1.1 \mathrm{~m}$. The two melters in the HLW facility together are designed to produce up to $7.5 \mathrm{MT}$ of glass per day at $100 \%$ availability. Further increases in HLW waste processing rates can potentially be achieved by increasing the melter operating temperature above $1150^{\circ} \mathrm{C}$, further optimization of the bubblers, and by increasing the waste loading in the glass product. Increasing the waste loading also has the added benefit of decreasing the number of canisters for storage.

The glass formulation efforts for the WTP baseline have been contractually compliant but conservative in terms of waste loadings that may be ultimately achievable. These formulations 
have been specified to ensure that the glasses are homogenous, contain little crystalline phases, are processable in joule-heated, ceramic-lined melters, and meet the WTP contract requirements. The overall WTP mission will require the immobilization of tank waste compositions that are dominated by mixtures of aluminum, chromium, bismuth, iron, phosphorous, zirconium, and sulfur compounds as waste loading-limiting components. Glass compositions for these waste streams have been developed based upon previous experience and current glass property models. In addition, however, DOE has initiated a testing program to develop and characterize HLW glasses with higher waste loadings [5]. Results of that work have demonstrated the feasibility of increases in waste-loading from about $25 \mathrm{wt} \%$ to $33-50 \mathrm{wt} \%$ (based on oxide loading) in the glass depending on the waste stream. It is expected that these higher waste loading glasses will reduce the HLW canister production requirement by about $25 \%$ or more. In addition, tests conducted with various HLW waste streams on the DM100 and DM1200 melters have demonstrated increases in glass production rates from 0 to 225 percent while increasing the processing temperature from $1150^{\circ} \mathrm{C}$ to $1175^{\circ} \mathrm{C}[1,6]$. Yet higher operating temperatures $\left(1200^{\circ} \mathrm{C}\right)$ have the potential to further increase both processing rate as well as waste loadings, both of which translate into significant cost savings.

Under a separate contract to support the WTP baseline, VSL has developed and tested glass formulations for WTP HLW waste compositions to provide data to meet the WTP contract requirements and to support system design activities [7-9]. That work is based upon small-scale batch melts ("crucible melts") using waste simulants. Selected formulations have also been tested in small-scale, continuously fed, joule-heated melters (DM100) [10-13] and, ultimately, in the HLW DM1200 Pilot Melter [6, 12-19]. Such melter tests provide information on key process factors such as feed processing behavior, dynamic effects during processing, secondary phase formation, processing rates, off-gas amounts and compositions, foaming control, etc., that cannot be reliably obtained from crucible melts. This sequential scale-up approach in the vitrification testing program ensures that maximum benefit is obtained from the more costly melter tests and that the most effective use is made of those resources.

The present glass formulation and melter testing work was aimed at one of the four waste streams previously specified by ORP [5]. Such testing supports the ORP basis for projection of the amount of Immobilized High Level Waste (IHLW) to be produced at Hanford and evaluation of the likely potential for future enhancements of the WTP over and above the present well-developed baseline. It should be noted that the compositions of the four ORP-specified waste streams differ significantly from those of the feed tanks (AZ-101, AZ-102, C-16/AY-102, and C-104/AY-101) that have been the focus of the extensive technology development and design work performed for the WTP baseline. In this regard, the work on the ORP-specified compositions is complementary to, and necessarily of a more exploratory nature, than the work in support of the current WTP baseline.

This report describes work performed to test new glass and feed formulations to assess the tendency for foaming during cooling of discharged glass and to determine glass melting rates for new glass formulations that have been developed for HLW with high concentrations of bismuth. The melter tests were intended to verify results from crucible-scale testing on improved glass formulations [2] with respect to mitigation of the tendency for foaming during cooling, product quality, and the potential for higher waste processing rates. The DM100 was selected as 
the platform for these tests due to its extensive previous use in processing rate determination for various HLW streams and glass compositions [1, 10-13, 19-28]. This work builds on previous work performed at VSL for the ORP to increase both waste loadings in HLW glass formulations and processing rates $[1,26-29]$.

\subsection{Test Objectives}

The primary objective of the work described herein was to test two glasses formulated for a high bismuth waste stream on the DM100 melter system. Testing was designed to determine processing characteristics and production rates, assess the tendency for foaming, and confirm glass properties. The glass compositions tested were previously developed to maintain high waste loadings and processing rates while suppressing the foaming [2] observed in previous tests [1].

\subsection{Quality Assurance}

This work was conducted under a quality assurance program that is based on Nuclear Quality Assurance (NQA)-1 2004 and NQA-2a (1990) Part 2.7 that is in place at the VSL. The program is compliant with applicable criteria of 10 CFR 830.120; Office of Civilian Waste Management DOE/RW-0333P, Quality Assurance Requirements and Description (QARD) Revision 20; the American Society of Mechanical Engineers (ASME) NQA-1, 2004; and DOE Order 414.1 C, Quality Assurance. This program is supplemented by a Quality Assurance Project Plan (QAPP) for WTP work [30] that is conducted at VSL. Test and procedure requirements by which the testing activities are planned and controlled are also defined in this plan. The program is supported by VSL standard operating procedures that were used for this work [31].

\subsection{DM100 Melter System}

\subsubsection{DM100 Feed System}

A schematic diagram of the DM100 vitrification system is shown in Figure 1.1. The melter feed is introduced in batches into a feed container that is mounted on a load cell for weight monitoring. The feed is stirred with a variable speed mixer and constantly recirculated except for periodic, momentary interruptions during which the weight is recorded. A peristaltic pump is used in order to provide a uniform delivery of feed to the melt surface. Feed is directed from the recirculation loop that extends to the top of the melter and then diverted to the peristaltic pump, which regulates the flow of feed through a Teflon-lined feed line and water-cooled feed tube into the melter. 


\subsubsection{Melter System}

Cross-sectional diagrams of the DM100-BL melter are shown in Figures 1.2.a-c. The DM100-BL unit is a ceramic refractory-lined melter fitted with five electrodes: two pairs of opposing Inconel 690 plate electrodes and a bottom electrode. Power can be supplied in either three-phase or single-phase configurations. All of the tests in the present work were performed with the upper and lower electrodes on each side connected together and powered by a single-phase supply; the bottom electrode was not powered. Melt pool agitation is achieved by either a removable lance entering from the top of the melter or a permanent bubbler installed through the bottom electrode. In these tests, the lance bubbler was used. The glass product is removed from the melter by means of an airlift discharge system. The melter has a melt surface area of $0.108 \mathrm{~m}^{2}$ and a variable glass inventory of between $110 \mathrm{~kg}$, when only the bottom pair of electrodes is used, and about $170 \mathrm{~kg}$ when both pairs of electrodes are used, which was the case in the present tests.

\subsubsection{Off-Gas System}

For operational simplicity, the DM100-BL is equipped with a dry off-gas treatment system involving gas filtration operations only. Exhaust gases leave the melter plenum through a film cooler device that minimizes the formation of solid deposits. The film-cooler air has a constant flow rate and its temperature is thermostatically controlled. Consequently, under steady-state operating conditions, the exhaust gases passing through the transition line (between the melter and the first filtration device) can be sampled at constant temperature and airflow rate. The geometry of the transition line conforms to the requirements of the 40-CFR-60 air sampling techniques. Immediately downstream of the transition line are cyclonic filters followed by conventional pre-filters and high efficiency particulate air (HEPA) filters. The temperature of the cyclonic filters is maintained above $150^{\circ} \mathrm{C}$ while the temperatures in the HEPAs are kept sufficiently high to prevent moisture condensation. The entire train of gas filtration operations is duplicated and each train is used alternately. An induced draft fan completes the system.

\section{$1.4 \quad$ Experimental Procedures and Methods}

\subsubsection{Feed Samples from Melter Tests}

Feed samples were taken directly from as-received drums and the melter feed recirculation line during each test. Feed samples were poured into a platinum/gold crucible and placed into a programmed furnace for drying and fusion to form a glass. The glass produced from this fusion is ground to less than 200 mesh and sealed in 20-ml vials for subsequent analysis by X-ray fluorescence spectroscopy (XRF) or by acid digestion followed by direct-current plasma atomic emission spectroscopy (DCP-AES) on the resulting solution. The feed samples are also characterized for their density, $\mathrm{pH}$, water content, and glass yield. 


\subsubsection{Glass Product}

The glass product is discharged from the melter into 5-gallon steel pails periodically using an air-lift system. The discharged product glass is sampled at the end of each test by removing sufficient glass from the top of the cans for compositional analysis and secondary phase determination. In addition, the Product Consistency Test (PCT, 7 days at $90^{\circ} \mathrm{C}$ ) and Toxicity Characteristic Leaching Procedure (TCLP) were performed on samples of the glass product from the DM100 melter tests. Prior to those tests, the PCT and TCLP were also performed on the crucible melt compositions that were selected for the melter tests to ensure their compliance with the present WTP contract requirements. All of these procedures are routinely conducted at VSL and, therefore, standard operating procedures (SOPs) are in place.

Sample preparation for chemical analysis typically involves size reduction and sieving. All samples are subjected to XRF analysis to determine the concentrations of all elements except boron and lithium. A series of National Institute of Standards and Technology (NIST) reference materials are used for confirmation of the XRF data. Boron and lithium are determined by total acid dissolution of ground glass samples in $\mathrm{HF} / \mathrm{HNO}_{3}$ and subjecting the resulting solutions to DCP-AES analysis.

\subsubsection{Canister Centerline Cooling (CCC)}

Glass samples were subjected to $\mathrm{CCC}$ [32] heat treatment to determine their foaming tendency. All CCC heat treatments were performed in large Pt/Au crucibles holding 45 grams of glass in order to provide sufficient volume to contain the sample in case of foaming. Glass samples after CCC were first cross-sectioned and visually inspected. After polishing, the CCC glass samples were optically scanned in reflection mode and the acquired images reviewed on a computer monitor for signs of development of gas bubbles during $\mathrm{CCC}$ heat treatment.

\subsubsection{Product Consistency Test (PCT)}

The product consistency test (PCT, ASTM C 1285) is used to evaluate the relative chemical durability of glasses by measuring the concentrations of the chemical species released from 100-200 mesh crushed glass $(75-149 \mu \mathrm{m})$ to the test solution (de-ionized water in this case). PCT tests on the HLW glasses are performed at $90^{\circ} \mathrm{C}$, in accordance with the current WTP contract requirement. The ratio of the glass surface area to the solution volume for this test is about $2000 \mathrm{~m}^{-1}$ (typically, $4 \mathrm{~g}$ of 100-200 mesh glass is immersed in $40 \mathrm{ml}$ of deionized water). All tests are conducted in triplicate, in 304L stainless steel vessels, and in parallel with a standard glass included in each test set. The internal standard is the Argonne National Laboratory Low Activity Waste Reference Material (ANL-LRM) glass [33] and/or the DWPF-Environmental Assessment (EA) glass [34], both of which have undergone round-robin testing. The leachates are sampled at predetermined times, the first of which is seven days. One milliliter of sampled leachate is mixed with $20 \mathrm{ml}$ of $1 \mathrm{M} \mathrm{HNO}_{3}$ and the resulting solution is analyzed by DCP-AES; another $3 \mathrm{ml}$ of sampled leachate is used for $\mathrm{pH}$ measurement. 
ORP-56288 Rev. 0

The Catholic University of America

Vitreous State Laboratory
Melter Testing of New High Bismuth HLW Formulations

Final Report, VSL-13R2770-1, Rev. 0

\subsubsection{Toxicity Characteristic Leaching Procedure (TCLP)}

The TCLP is performed at VSL using SW-846 Method 1311, which employs leaching of crushed glass $\left(<3 / 8^{\prime \prime}\right)$ in a sodium acetate buffer solution for 18 hours at $22^{\circ} \mathrm{C}$ with constant end-over-end agitation. A mass of about 100 grams of glass is leached in 2 liters of TCLP extract, according to the extraction method for non-volatiles. The surface area to volume ratio for this test is about $20 \mathrm{~m}^{-1}$, which is about two orders of magnitude lower than that in the PCT. The leachates are analyzed by DCP-AES according to VSL standard operating procedures. 


\section{SECTION 2.0 \\ WASTE SIMULANT AND GLASS FORMULATIONS}

\subsection{Waste Simulants}

The waste stream compositions previously provided by ORP are given in Table 2.1 on an oxide basis [5]. The present work focused exclusively on the bismuth limited waste stream in response to the foaming observed at crucible scale during CCC heat treatment [1]. Actual HLW Hanford tank wastes are aqueous solutions with suspended solids and dissolved salts including hydroxides, nitrates, nitrites, halides, and carbonates. For the purpose of the previous [1,2] and present work, the concentrations of the volatile components (i.e., carbonate, nitrite, nitrate, and organic carbon) were assumed to be similar to those found for the AZ-102 HLW waste [17]. With the waste composition defined, formulation of the HLW waste simulant proceeds in a straightforward fashion. In general, oxides and hydroxides are used as the starting materials, with a slurry of iron (III) hydroxide ( $13 \%$ by weight) as one of the major constituents. Volatile inorganic components are added as the sodium salts, whereas organic carbon is added as oxalic acid. Although crucible melts using the appropriate radioactive components (i.e., thorium and uranium) were prepared and evaluated previously, radioactive components were omitted and the waste composition was renormalized in the simulated waste to be used for melter testing. Finally, the water content was adjusted to target a glass yield of $500 \mathrm{~g}$ of glass per liter of feed. The composition of the waste simulant formulated to produce $100 \mathrm{~kg}$ of waste oxides is given in Table 2.2.

\subsection{Glass and Melter Feed Formulations}

The compositions and properties of the high bismuth glasses selected for melter testing are given in Tables 2.3 and 2.4. These glasses were developed to reduce the tendency for foaming during canister cooling and potentially provide higher waste processing rates [2]. The selected glass formulations, HLW-E-Bi-F3 and HLW-E-Bi-F9, meet all of the processing and product quality requirements imposed for these tests and have a waste oxide loading of $50 \mathrm{wt} \%$. This exceeds both the minimum and maximum expected waste loadings provided in the previous scope of work [5] of $15 \mathrm{wt} \%$ and $40 \mathrm{wt} \%$, respectively. The glasses contain $6.7 \mathrm{wt} \% \mathrm{Bi}_{2} \mathrm{O}_{3}$ and close to $5 \mathrm{wt} \% \mathrm{P}_{2} \mathrm{O}_{5}$. The $\mathrm{Bi}_{2} \mathrm{O}_{3}$ content is more than three times the WTP contract minimum for $\mathrm{Bi}_{2} \mathrm{O}_{3}(2 \mathrm{wt} \%)$. The PCT leach rates are lower than those of the DWPF-EA glass by factors of between about five to thirty and the TCLP leachate concentrations are all below the WTP delisting limits. The measured processing parameters are all within acceptable ranges. The glass formulations have the same $50 \%$ waste loading as the previous formulation (HLW-E-Bi-6) tested [1] but somewhat higher PCT leach rates [2]. The viscosities of the two formulations are lower than that for the HLW-E-Bi-6 composition, which was towards the high end of the acceptable range. 
Feed recipes for both glass formulations are provided in Tables 2.5 and 2.6. Both feeds utilize silica as an additive source for silicon and soda ash as a source of sodium. Borax is used as a source of both sodium and boron in the HLW-Bi-F3 formulation; boric acid is used as a boron source for the HLW-Bi-F9 formulation. Kyanite and lithium carbonate are used in the HLW-Bi-F9 formulation as sources of aluminum and lithium, respectively. The high bismuth waste simulant was produced by NOAH Technologies Corporation, the supplier of simulant and feed samples used in previous testing on the DM100 and DM1200 melter systems, according to VSL specifications and shipped in 55-gallon drums. This waste simulant was used to produce batches of each of the HLW-Bi-F3 and HLW-Bi-F9 feed formulations by adding appropriate amounts of the various additives at VSL. 


\section{SECTION 3.0 DM100 MELTER OPERATIONS}

Four melter tests were conducted on the DM100-BL vitrification system between 8/20/12 and 8/31/12 with a high bismuth waste simulant and two high waste loading glass compositions. One test employed optimized bubbling while the other test employed a constant bubbling rate of $9 \mathrm{lpm}$ for each glass composition. These tests produced over eleven hundred kilograms of glass from over three metric tons of feed. Prior to the melter tests, the melt pool was turned over to a high bismuth composition using feed remaining from previous DM100 and DM1200 tests [1, 2].

In these tests, the glass temperature was held constant at $1150^{\circ} \mathrm{C}$ while feeding in order to determine the effect of the test variables on production rate and processing properties as well as to facilitate comparison with previously conducted tests. All tests were conducted with the same high bismuth waste simulant, feed solids content targeted at $500 \mathrm{~g}$ glass per liter of feed, and a nominal duration of fifty hours. The two tests with each of the two glass compositions were distinguished by optimizing bubbling during the first test in order to maximize production rate and fixing the bubbling rate at $9 \mathrm{lpm}$ per minute in the second test in order to provide a direct comparison to the results from previous tests. Summaries of the tests are provided in Tables 3.1 and 3.2 for tests conducted with the HLW-Bi-F3 and HLW-Bi-F9 glass compositions, respectively. Attempts were made to replicate the melter configuration and operating conditions used for previous tests with HLW simulants [1, 10-13, 19-28]. These conditions include a near-complete cold cap, which is between $80-95 \%$ melt surface coverage for the DM100 since a $100 \%$ cold cap tends to lead to "bridging" in smaller melters. The bubbling rate was either fixed at a target of $9 \mathrm{lpm}$ or optimized, and the feed rate was adjusted to maintain a complete cold cap. This use of fixed bubbling is in contrast to some previous tests where the production rate was fixed between 1000 and $1050 \mathrm{~kg} / \mathrm{m}^{2} /$ day and the bubbling rate was adjusted to maintain the complete cold cap [12-14, 23].

Both feed formulations were processed without any significant difficulties throughout the tests. Cold cap conditions were similar to the range of conditions observed in previous tests with HLW feeds [1, 10-13, 19-27]. The feed formed some shelves and bridges, although not to the rate limiting extent observed while processing some high aluminum formulations $[1,21]$ or some high iron formulations [19]. Shelves were typically observed after glass discharging as a result of residual feed adhering to the walls of the melter, which would lose contact with the melt pool surface once the level fell. Manual methods were used to dislodge these deposits without any interruptions in feeding. Short, routine interruptions were required during testing to transfer feed to the feed tank, adjust the feed line in the peristaltic pump as a result of wear from the pump rollers, and perform other maintenance activities. No foamy glass was observed in the glass discharge and no foam was observed on the melt pool surface or cold cap. Although no foaming was observed during cooling of discharged glass, this is inconclusive because of the faster cooling rates of glass in the five gallon pails than for the WTP CCC; for this reason, foaming was not observed in DM100 tests with the original glass formulation [1] but was observed on $\mathrm{CCC}$ heat treatment. Accordingly, samples of the product glasses from both feed formulations were collected and subjected to CCC heat treatment, as discussed in Section 4. 
Figures 3.1.a and 3.1.b illustrate the glass production rates as moving hourly and cumulative averages during testing. In three of the four tests, the instantaneous and cumulative rates were relatively constant throughout the 50 hour tests; in the test with the HLW-Bi-F9 glass formulation at optimized bubbling, approximately 25 hours was required to reach the maximum stable rate. Steady state production rates are estimated for each test as the maximum sustainable instantaneous rate; these varied with glass composition and increased with bubbling optimization for each composition. Steady state production rates for current and previous tests [1] conducted at $9 \mathrm{lpm}$ fixed bubbling or optimized bubbling with the same high bismuth waste composition are tabulated in Table 3.3. Included in Table 3.3 is a steady state processing rate of $1100 \mathrm{~kg} / \mathrm{m}^{2} /$ day for the HLW-E-Bi-6 glass formulation at a temperature of $1150^{\circ} \mathrm{C}$ and optimized bubbling, which was determined during turnover with that feed before the start of the present tests. This value is in agreement with the rate estimated from tests conducted previously at a temperature of $1175^{\circ} \mathrm{C}$. Taken together, the past and present test results show significant increases in production rate with the new HLW-Bi-F9 glass formulation as compared to the previous formulation (HLW-E-Bi-6) and the new HLW-Bi-F3 glass formulation, as well as increases in production rate for all glass formulations with optimized bubbling:

- Glass production rates for the HLW-E-Bi-6 formulation and the new HLW-Bi-F3 glass formulation were similar when using fixed (830 vs. $770 \mathrm{~kg} / \mathrm{m}^{2} /$ day) and optimized bubbling (1100 vs. $1035 \mathrm{~kg} / \mathrm{m}^{2} /$ day).

- Glass production rate increased by $100 \%$ (1660 vs. $830 \mathrm{~kg} / \mathrm{m}^{2} /$ day) over that of the HLW-E-Bi-6 formulation when processing the new HLW-Bi-F9 glass formulation at fixed bubbling.

- Glass production rate increased by $82 \%$ (2000 vs. $1100 \mathrm{~kg} / \mathrm{m}^{2} /$ day) over that of the HLW-E-Bi-6 formulation when processing the new HLW-Bi-F9 glass formulation at optimized bubbling.

- Glass production rate increased by $20 \%$ (2000 vs. $1660 \mathrm{~kg} / \mathrm{m}^{2} /$ day) with bubbling optimization while processing the new HLW-Bi-F9 glass formulation.

- Glass production rate increased by $25 \%$ (1035 vs. $830 \mathrm{~kg} / \mathrm{m}^{2} /$ day) with bubbling optimization while processing the new HLW-Bi-F3 glass formulation.

The results of various operational measurements that were made during these tests are given in Tables 3.4 and 3.5. Glass temperatures are shown in Figures 3.2.a and 3.2.b, plenum temperatures in Figures 3.3.a and 3.3.b, electrode temperatures in Figures 3.4.a and 3.4.b, glass resistance in Figures 3.5.a and 3.5.b, and melt pool bubbling in Figures 3.6.a and 3.6.b; electrode power is included in the figures with electrode temperatures and glass resistance. Bulk glass temperatures (measured at 5, 10, and 16 inches from the bottom of the melt pool) were largely within $10^{\circ} \mathrm{C}$ of the target glass temperature of $1150^{\circ} \mathrm{C}$ throughout the vast majority of the tests. Glass temperatures closer to the top of the melt pool (measured at 27 inches from the bottom) are 
not reliable indicators of bulk glass temperatures as a result of their sensitivity to variations in the level of glass in the melter and gradients near the melt surface. The temperature of the air lift increases from the discharge chamber temperature of about $1000^{\circ} \mathrm{C}$ to about $1100^{\circ} \mathrm{C}$ during glass discharge events. The two electrode pairs were typically 50 to $100^{\circ} \mathrm{C}$ colder than the glass pool, depending on the measured points in the glass pool and electrodes, the amount of bubbling used, and the time within the test. The bottom electrode, which was not powered, was 350 to $400^{\circ} \mathrm{C}$ colder than the powered side electrodes.

Plenum temperatures ranged from $380^{\circ} \mathrm{C}$ to $520^{\circ} \mathrm{C}$ and from $480^{\circ} \mathrm{C}$ to $610^{\circ} \mathrm{C}$ during steady state processing for tests with the HLW-Bi-F3 and HLW-Bi-F9 glass compositions, respectively. The lower plenum temperatures while processing the HLW-Bi-F3 glass composition indicate the formation of a thicker more insulating cold cap for that feed composition. Higher plenum temperatures were measured at the beginning of both tests during the development of the cold cap. On average, plenum temperatures were about $50^{\circ} \mathrm{C}$ lower while optimizing bubbling for each composition. Plenum temperatures measured in the thermowell were typically about $20^{\circ} \mathrm{C}$ lower than those measured by the exposed thermocouple.

Bubbling rates ranged mostly from 10.5 to 14 and 9.5 to $11 \mathrm{lpm}$ while being optimized during the processing of the HLW-Bi-F3 and HLW-Bi-F9 glass compositions, respectively. The lower amount of bubbling used while processing the HLW-Bi-F9 composition is further evidence that this formulation is easier to process than the other two glass formulations for the high bismuth waste. The target bubbling rate of $9 \mathrm{lpm}$ was maintained throughout the second test with each of the two compositions. Power supplied to the electrodes increased with increasing glass production rate, as expected. The power required while processing the HLW-Bi-F9 composition at 2000 and $1660 \mathrm{~kg} / \mathrm{m}^{2} /$ day was 27 and $24 \mathrm{~kW}$, respectively, and while processing the HLW-Bi-F3 composition at 1035 and $770 \mathrm{~kg} / \mathrm{m}^{2} /$ day the power was 17 and $16 \mathrm{~kW}$, respectively. The average power usage normalized to glass production was relatively low, 3.3 $4.3 \mathrm{kWhr} / \mathrm{kg}$, decreasing with increasing production rate. Much of the supplied energy is used to maintain the glass pool at the target melt temperature (i.e., the essentially constant idling power); thus higher production rates result in relatively lower normalized power usage. The melt pool resistance decreased over the course of the tests from 0.1 to $0.075 \mathrm{ohms}$ in response to compositional changes and changes in melt pool bubbling rate.

The gas temperature at the film cooler was slightly below $300^{\circ} \mathrm{C}$ and depended on the plenum temperature, the amount of added film cooler air, and the temperature of the added film cooler air. Drops of fifteen to twenty degrees centigrade in gas temperature were observed across the (insulated) transition line; the high temperature is maintained in order to prevent condensation in the downstream filtration units. 


\section{SECTION 4.0 \\ FEED SAMPLE AND GLASS PRODUCT ANALYSIS}

\subsection{Analysis of Feed Samples \\ 4.1.1 General Properties}

Feed samples from each test were analyzed to confirm physical properties and chemical composition. Samples were taken during melter testing from an inline sampling port while the as-received waste simulant was sampled directly from the drum. Sample names and measured properties are given in Table 4.1. Density, $\mathrm{pH}$, water content, glass conversion ratio, and oxide composition by XRF and boron and lithium concentrations by DCP were measured on all samples. The measured glass conversion ratios for all feed samples were within three percent of the target on a weight per weight basis, validating the use of the target conversion ratio for calculating glass production rates. The water content, density, and glass yield varied within a narrow range for the feed samples. The waste simulant contained more water and had lower solids content than the completed melter feed, as expected. The $\mathrm{pH}$ of the waste simulant was decreased by the glass former additives, particularly in the HLW-Bi-F9 composition due to the use of boric acid as the boron source.

\subsubsection{Chemical Composition}

The methods used for analysis of waste and feed sample chemical compositions are described in Section 1.4. The boron and lithium oxide concentrations from the DCP-AES analysis were used for normalizing the XRF data since their concentrations were not determined by XRF. These results, compared to the target composition in Table 4.2, generally show agreement with the target composition and corroborate the consistency of the feed for the major elements. The waste simulant was fused and analyzed in the same manner as a glass, although an actual glass was not formed due to low concentrations of glass formers. Although the XRF procedure was developed for glass samples, the XRF analysis of the waste simulant compares favorably with the target waste composition for all the major constituents, confirming the composition of the as-received waste. DCP analysis of the boron and lithium contents of the waste simulant matches the low target concentrations. The average analysis of the feed shows that all oxides with target concentrations greater than one weight percent deviated by less than $10 \%$ from target except for boron and nickel for the HLW-Bi-F3 composition. The relative deviations were $-10.8 \%$ for boron and $14.8 \%$ for nickel but exhibited deviations of about half these levels in the product glass from the end of testing with the HLW-Bi-F3 composition. Low concentrations of chlorine, manganese, and strontium were found, even though they are not included in the target compositions. Any measured deviations from target composition are considered minor and are therefore not expected to have any significant effect on glass properties or testing objectives. 


\subsection{Analysis of Glass Samples}

Over $1100 \mathrm{~kg}$ of glass was produced in these tests. The glass was discharged from the DM100 melter periodically into 5-gallon carbon steel pails using an air lift system. The discharged product glass was sampled by removing sufficient glass from the top of each pail for total inorganic analysis. Product glass masses and discharge date are given in Table 4.3. Glass samples were also taken by inserting a threaded metal rod directly into the glass pool. These "dip" samples serve to document the composition of the glass pool before and after each test.

\subsubsection{Compositional Analysis of Discharge and Dip Sample Glasses}

All discharge glass samples were crushed and analyzed directly by XRF. Select glasses were subjected to DCP analysis to determine boron and lithium concentrations since these are not determined by XRF; boron and lithium concentrations were interpolated from the analyzed samples for the remainder of the glasses in the test. Fluorine analysis by XRF required a polished monolith as opposed to the standard ground glass preparation used for the other elements. Every third or fourth discharged glass sample was directly analyzed for fluorine; fluorine concentrations of other glasses were then interpolated between the measured values. The XRF analyzed compositions of discharged and dip glass samples are provided in Tables 4.4 and 4.5. The majority of the XRF analysis results compare favorably to their corresponding target values and feed sample analyses (see Section 4.1.2). Oxides with a target concentration greater than one weight percent showed less than 10\% deviation from the target values for glasses from the end of testing each composition with the exception of bismuth in tests with the HLW-Bi-F3 composition and nickel and phosphorus in tests with the HLW-Bi-F9 composition. All oxides with target concentrations greater than one weight percent deviated from target by less than thirteen relative percent. The amount of sulfur in the product glass is higher than analyzed in the feed samples, indicating greater loss of sulfur during crucible melting of feed than vitrification while processing through the melter with a cold cap on the melt surface. Small amounts of cadmium, chlorine, manganese, and strontium were measured in the glasses despite not being included in the current target composition as a result of their presence in the melt pool prior to these tests or in the feed as a contaminant.

Compositional trends for selected constituents shown in Figures 4.1 - 4.7 illustrate the closeness to targets over the majority of the tests. Target oxide concentrations for all elements except those derived from additives (aluminum, boron, lithium, silicon, and sodium) remain fixed throughout the tests. At the onset of testing, most constituents are close to target concentrations as a result of the pre-test turnover with the HLW-E-Bi-6 glass composition, which also has a $50 \mathrm{wt} \%$ loading of the same high bismuth waste simulant composition and many of the same additives. Sodium increases in concentration at the expense of boron as a result of the change in additives during the transition to the HLW-Bi-F3 composition. Also, manganese present in the melt pool at the beginning of testing but not present in the target glass composition decreases in concentration to the trace contaminant levels measured in feed samples. Transitioning from the HLW-Bi-F3 to the HLW-Bi-F9 composition in the latter portion of testing, aluminum and boron increase in concentration at the expense of silicon and sodium as a 
result of the change in additives. The analyzed concentrations of waste components largely approximate their respective target concentrations over the course of the tests with phosphorus and bismuth above target and nickel below target while processing the HLW-Bi-F9 composition. Bismuth and nickel concentrations drop by 1.2 and 0.5 absolute weight percent, respectively, during the idling period of approximately 60 hours between processing the HLW-Bi-F3 and HLW-Bi-F9 compositions (approximately $400 \mathrm{~kg}$ glass production). This abrupt decrease in concentrations is suggestive of constituents settling out of the melt pool while the melt pool is not actively being mixed through bubbling. Sulfur and fluorine concentrations were well below target concentrations throughout testing due to volatilization. Lower concentrations of these volatiles in the product glasses during the latter portion of testing combined with higher concentrations monitored in the exhaust stream suggest that the HLW-Bi-F9 glass composition is less accommodating to these volatile components.

\subsubsection{Chemical Durability of Discharge Glasses}

Glass discharge samples from the end of tests with each of the two glass compositions were evaluated for chemical durability using the PCT and TCLP methods. The PCT results are compared to those for the benchmark DWPF-EA glass in Table 4.6 and the TCLP results are compared to the WTP delisting limits $[35,36]$ and Universal Treatment Standard (UTS) limits in Table 4.7. Also included are results from the same target glass compositions produced during glass formulation development [2]. The chemical durability determined for the melter glasses by both of these methods is excellent. All measured PCT concentrations and normalized leach rates on discharge glass samples are at least five times lower than the corresponding values for the DWPF-EA glass. All regulated TCLP leachate concentrations are less than $0.5 \mathrm{mg} / \mathrm{l}$ and more than a factor of fifty less than WTP delisting limits. All measured concentrations are also well below the UTS limits. The chemical durability of melter glasses is comparable to that of crucible melt glasses targeting the same composition [2]. Also consistent with previous results for the crucible glasses [2], measured PCT and TCLP Bi leachate concentrations were higher for the HLW-Bi-F9 composition while $\mathrm{Ni}$ and $\mathrm{Cr}$ TCLP leachate concentrations were higher for HLW-Bi-F3 composition. These results confirm that different glass compositions can be formulated for the high bismuth HLW stream with faster processing rates without compromising the quality of the glass product.

\subsubsection{Canister Centerline Cooling (CCC) of Glass Samples}

The foaming tendency of the two new Bi-limited waste glasses was tested by subjecting glass samples from the end of the melter tests processing each of the two compositions to HLW $\mathrm{CCC}$ heat treatments. A crucible with 45 grams of melter glass was used for the CCC tests. The glass samples after CCC heat treatment were sectioned through the center, perpendicular to the top surface. The samples had a height of $1.2 \mathrm{~cm}$ at the center. The cross sections were polished and examined for signs of foaming. Visual inspection of the two CCC samples did not show any signs of foaming, although a few small voids were evident along the glass/crucible interfaces. The samples were then further investigated for any indications of foaming and the presence of 
secondary phases by analysis using SEM/EDS. The results from SEM/EDS analyses of the samples are as follows:

LBL-G-8A, HLW-Bi-F3 formulation: There was no significant occurrence of vesicles in this sample. The sample showed the presence of three crystalline phases: lithiophosphate $(4.4 \pm$ 0.6 vol. \%), calcium phosphate/apatite $(2.3 \pm 0.2 \mathrm{vol} . \%)$, which occurred throughout the sample in rosette-shaped clusters 3 to $5 \mu \mathrm{m}$ across with individual crystallites $<1 \mu \mathrm{m}$ in size, and $\mathrm{Fe}, \mathrm{Ni}$, $\mathrm{Cr}$ spinels $(2.5 \pm 0.9$ vol. \%), which occurred throughout the sample in a 1-3 $\mu \mathrm{m}$ size range usually at the centers of phosphate rosettes, and in larger size, 10-50 $\mu \mathrm{m}$, sparsely scattered throughout, and somewhat more concentrated at interfaces: crucible surfaces, where a few large clusters 100-200 $\mu \mathrm{m}$ across were found, and in smaller size, 5-10 $\mu \mathrm{m}$, at the meniscus. Representative SEM images of the glass and secondary phases are provided in Figure 4.8.

LBL-G-71A, HLW-Bi-F9 formulation: This sample showed the presence of three crystalline phases: lithiophosphate $(3.9 \pm 1.3$ vol. \%), calcium phosphate/apatite $(0.83 \pm 0.36$ vol. \%) and $\mathrm{Fe}, \mathrm{Ni}, \mathrm{Cr}$ spinels $(3.5 \pm 1.4$ vol. \%). There was also a small amount of vesicles in the sample $(0.48 \pm 0.35$ vol. \%). The microstructure of the sample varied considerably throughout its volume. The lithiophosphate, which here had a platelet morphology, was found in some areas (e.g., Figure 4.9.a) in its incipient phases of crystallization with platelets only up to $10-20 \mu \mathrm{m}$ wide, but in other areas of ripened growth there were many platelets up to a few hundred $\mu \mathrm{m}$ wide. The incipient growth regions were more likely to be populated with vesicles and small crystals of the other two phases. The apatite occurred as columnar, frequently hollow, crystals only $1 \mu \mathrm{m}$ or less wide but extending many $\mu \mathrm{m}$ in length. Strings of small spinels $(\leq 5 \mu \mathrm{m})$ were often found along the lithiophosphate platelets. Large $(30-60 \mu \mathrm{m})$ spinels were scattered throughout the sample and showed considerable concentration due to settling within 3 to $4 \mathrm{~mm}$ of the bottom of the crucible (Figure 4.9.b).

The types and amounts of crystalline phases in the canister cooled melter glass samples is generally consistent with the data from isothermal heat treatment of crucible melt samples generated during development of the glass formulations [2]. 


\section{SECTION 5.0 MONITORED OFF-GAS EMISSIONS}

\subsection{Particulate Sampling}

The melter exhaust was sampled for metals/particles according to 40-CFR-60 Methods 3, 5, and 29 at steady-state operating conditions during each test segment. The concentrations of off-gas species that are present as particulates and gaseous species that are collected in impinger solutions were derived from laboratory data on solutions extracted from air samples (filters and various solutions) together with measurements of the volume of air sampled. Particulate collection required isokinetic sampling, which entails removing gas from the exhaust at the same velocity that the air is flowing in the duct (40-CFR-60, Methods 1-5). Typically, a sample size of 30 dscf was taken at a rate of between 0.5 and $0.75 \mathrm{dscfm}$. Total particulate loading was determined by combining gravimetric analysis of the standard particle filter and chemical analysis of probe rinse solutions. An additional impinger containing $2 \mathrm{~N} \mathrm{NaOH}$ was added to the sampling train to ensure complete scrubbing of all acid gases and, particularly, iodine. The collected materials were analyzed using direct current plasma atomic emission spectroscopy for the majority of the constituents and ion chromatography (IC) for anions. Melter emission fluxes are compared to feed fluxes and emission samples taken while processing the same glass composition in Table 5.1. Notice the distinction that is made between constituents sampled as particles and as "gas". The "gaseous" constituents are operationally defined as those species that are scrubbed in the impinger solutions after the air stream has passed through a $0.3 \mu \mathrm{m}$ heated filter. All samples were well within the $90-110 \%$ limits for isokinetic sampling.

Particulate emissions constituted 0.18 to 0.39 percent of feed solids. This level of carryover is mostly well below the range measured while processing various feeds containing high iron HLW simulants processed on the same melter at a temperature of $1150^{\circ} \mathrm{C}$ : $\mathrm{AZ}-102$ (0.57 - 1.47 percent) [19]; C-106/AY-102 SIPP (0.61 to 0.81 percent) [11]; C-106/AY-102 enhanced glass formulation ( 0.66 to 0.71 percent) [28]; the former C-106/AY-102 baseline (0.3 0.74 percent) [21]; HLW AZ-101 (0.46 percent) [25]; and waste compositions limited by the formation of iron and chromium mineral phases (0.47 - 1.81 percent) [24]. However, the emissions from the current tests were within the range of measured carryover for previous tests with chromium, bismuth, aluminum, and aluminum plus sodium limited HLW wastes (0.04 $0.57)[1,26,27]$ and processed under the same melter conditions. Carryover is a function of the amount of volatile constituents in the feed and the conditions in the melter, particularly the completeness and uniformity of the cold cap. The relatively low emissions in the current tests were a result of the low volatile content of the feed and the complete and relatively uniform cold cap maintained during testing. Much higher levels of carryover were observed in tests with high volatile contents (rhenium, cesium, and halogens) [23] and very poor cold cap development [24]. Comparison of emissions while processing the three different glass formulations for the bismuth waste stream reflects the nature of the cold cap; lower emissions while processing the HLW-Bi-F9 formulation (0.18 percent), which processed at the highest rate and with a more uniform cold cap than was the case for the HLW-Bi-F3 (0.30 percent) and HLW-E-Bi-6 (0.23 
percent) formulations. No clear trend of increased emissions at higher bubbling rates was discernable.

As expected, the feed element emitted at the lowest melter decontamination factor (DF) was clearly sulfur, followed by fluorine. Other elements exhibiting some volatile behavior were boron, chromium, and potassium. The relative carryovers of barium, lithium, titanium, and zinc are difficult to evaluate due to their low target concentrations and trace contamination in the feed. Boron, fluorine, and sulfur were the only elements detected in the impinger solutions collected downstream of the heated particle filter in the sampling train, which constitutes the "gas" fraction of the melter emissions.

\subsection{Gases Monitored by FTIR}

Melter emissions were monitored in each test for a variety of gaseous components, most notably $\mathrm{CO}$ and nitrogen species, by Fourier Transform Infra Red Spectroscopy (FTIR). The off-gas system temperature is maintained well above $100^{\circ} \mathrm{C}$ beyond the sampling port downstream of the DM100 HEPA filter to prevent analyte loss due to condensation prior to monitoring. The data, therefore, represent the relative concentrations of volatile gaseous species in the melter exhaust. A summary of the range and average concentrations of gaseous species monitored during testing is provided in Table 5.2. The analytes listed in Table 5.2 are those that were thought likely to be observed during the tests based on previous work; no other species were detected in the off-gas stream by FTIR. The concentrations of four monitored species, nitrogen oxides, hydrogen fluoride, and water are plotted in Figures 5.1 - 5.6. Generally, emissions of nitrogen oxides and products of incomplete combustion from the DM100 were relatively low as a result of the low concentrations of nitrogen, organic carbon, and ammonia in the feed. The most abundant nitrogen species detected was NO, which is in keeping with previous melter tests with both HLW and LAW feeds. Nitrogen dioxide concentrations were about 8 to 10 times lower than NO concentrations and little or no nitrogen was detected as other species. The concentrations of water and NO in the melter exhaust varied with the feed rate over the course of the tests, as would be expected. The scatter in the emissions data over the course of the tests is due in part to changes in the cold cap. Hydrogen fluoride concentrations increase over the course of the tests, which is consistent with the gaseous fluoride concentrations measured using Method 5-type protocols shown in Table 5.1. The progressively higher concentrations of hydrogen fluoride likely reflect the loading of the glass with fluorine over the course of the tests. 


\section{SECTION 6.0 SUMMARY AND CONCLUSIONS}

The original glass formulation that was developed by VSL several years ago for the ORPspecified high bismuth HLW stream is HLW-E-Bi-6 [1]. However, that work also identified a potential issue related to glass foaming during the projected canister cooling conditions for glass discharged from the WTP HLW melter. This finding was subsequently confirmed through testing on the DM1200 HLW Pilot Melter at VSL [2]. Further testing was performed to identify the origin of this phenomenon and to thereby mitigate this behavior through the development of modified glass formulations that are less prone to foaming upon cooling [2]. In addition, melter tests had showed that the glass production rate for the original high bismuth glass formulation was only marginally greater than the WTP requirement [1]. Accordingly, the primary objectives of the present work were to evaluate the new glass formulations (HLW-Bi-F3 and HLW-Bi-F9) that have been developed for the same high bismuth waste stream with respect to processing rate and the tendency to foam during cooling.

A series of melter tests were conducted on the DM100 using a high bismuth HLW simulant with the newly developed glass formulations, HLW-Bi-F3 and HLW-Bi-F9. The tests were conducted at $1150^{\circ} \mathrm{C}$ at the nominal bubbling rate of $91 \mathrm{pm}$ and also with optimized bubbling to achieve maximum production rates; these conditions were selected to allow comparison to results obtained previously with high bismuth HLW simulants [1]. The feed rate was adjusted to provide the desired complete cold cap. The principal results of these tests can be summarized as follows:

- No foaming was observed during cooling for either of the new glass formulations.

- Glass production rates for the baseline formulation (HLW-E-Bi-6) and the new HLW-Bi-F3 glass formulation were very similar when using fixed (830 vs. 770 $\mathrm{kg} / \mathrm{m}^{2} /$ day) and optimized bubbling (1100 vs. $1035 \mathrm{~kg} / \mathrm{m}^{2} /$ day).

- Glass production rate increased by $100 \%$ (1660 vs. $830 \mathrm{~kg} / \mathrm{m}^{2} /$ day) over the original high bismuth formulation (HLW-E-Bi-6) when processing the new HLW-Bi-F9 glass formulation at fixed bubbling.

- Glass production rate increased by $82 \%$ (2000 vs. $1100 \mathrm{~kg} / \mathrm{m}^{2} /$ day) over the original high bismuth formulation (HLW-E-Bi-6) when processing the new HLW-Bi-F9 glass formulation at optimized bubbling.

- Glass production rate increased by $20 \%$ (2000 vs. $1660 \mathrm{~kg} / \mathrm{m}^{2} /$ day) with bubbling optimization while processing the new HLW-Bi-F9 glass formulation.

- Glass production rate increased by $25 \%$ (1035 vs. $830 \mathrm{~kg} / \mathrm{m}^{2} /$ day) with bubbling optimization while processing the new HLW-Bi-F3 glass formulation. 
The results from the melter tests confirmed those from the crucible scale glass formulation work, demonstrating the absence of foaming during cooling and increase in glass production rates with the new glass formulations. The results also demonstrate that processing rates can be increased by a factor of about two over the WTP HLW baseline requirement using these new formulations in combination with optimization of melt pool bubbling.

Both of the selected glasses meet all of the WTP product quality constraints. One of the two glasses selected for melter testing (HLW-Bi-F3) also meets all of the WTP processing constraints (e.g., viscosity $\sim 43 \mathrm{P}$ at $1150 \mathrm{C} ; 1$ vol\% crystals after heat treatment for 72 hours at $950^{\circ} \mathrm{C}$ ). The second glass (HLW-Bi-F9) is more aggressive in terms of challenging the WTP processing constraints (viscosity $\sim 18.5 \mathrm{P} ; 2.2$ vol\% crystals) and was also selected for melter testing in order to assess its processability. VGF test results on this glass predicted it to also have a higher processing rate than HLW-Bi-F3, which was subsequently confirmed in the melter tests. Furthermore, no processing issues were observed during melter tests with this more aggressive formulation. Such data are valuable in assessing the potential for pushing beyond the present WTP processing limits, particularly in view of the rather limited data in this area. It is worth noting that, although no processing issues were observed with this formulation, previous tests with an iron-limited formulation [24] showed that the processing rate decreased as the concentration of spinel increased above $1.5 \mathrm{vol} \%$. In addition, crystal settling in the melter was observed at higher crystal concentrations. Clearly, more data are needed to define the crystallization constraints for glass formulations to be used for waste processing at the WTP.

During each processing rate test the melter exhaust was sampled for particulate and gaseous species to determine the effect of changing glass composition and bubbling rate on emissions. Particulate emissions from the melter constituted 0.18 to 0.39 percent of feed solids, consistent with previous tests with this high bismuth HLW stream. Melter DFs were determined for most elements in the feed. The most volatile components were sulfur and fluorine, which were present in the exhaust stream as particulate and gaseous species. Other elements exhibiting volatile behavior in some of the tests include boron, chromium, and potassium. Gaseous emissions of nitrogen oxides and byproducts of incomplete combustion, such as carbon monoxide and ammonia, were very low due to the lack of nitrates and organic carbon in the feed.

Glass samples from the melter tests were subjected to leach testing using the PCT and TCLP methods in order to evaluate product quality. The glass products significantly out-performed the DWPF-EA benchmark glass on the PCT leaching procedure and exhibited TCLP leachate concentrations that were well below the WTP delisting limits, confirming results obtained on crucible glasses. Glass samples from melter tests were also subjected to canister cooling heat treatment to evaluate the potential for foaming. Foaming was not observed in canister cooled glass samples, which is consistent with the crucible test results obtained during the development of these formulations [2]. 


\subsection{Recommendations for Future Work}

The results of the testing presented herein further demonstrate the viability of the enhancement and optimization strategies that have been developed in previous work for ORP [1, 2, 24, 26-28]. Furthermore, the results have the potential for enormous savings in cost and schedule. As a result, it is recommended that testing and evaluation of these strategies be continued in order to provide a solid basis for their broad implementation in order to maximize the cost and schedule benefits while minimizing technical risk. Further work that is recommended for optimization of processing of WTP high bismuth HLW feed is outlined below.

- Glass Formulation: Despite the limited nature of the present study, very significant enhancements of glass processing rates have been demonstrated. Formulation efforts have been successful in identifying glass formulations that do not foam during canister cooling, maintain high waste loading and production rates, and still meet processing and quality criteria. The results from the glass formulation work indicate that further improvements may be possible through a subsequent phase of glass formulation optimization using the results of the present work as a basis.

- Scale-Up Testing: As in the previous enhancement work for ORP, testing should be extended to larger-scale melter systems in order to address potential risks associated with scale-up, particularly with respect to processing rates. Testing should be conducted at the DM1200 WTP HLW Pilot Melter scale $\left(1.2 \mathrm{~m}^{2}\right)$. Optimization of bubbling rate is a critical variable and therefore testing with bubblers in the prototypical orientation at larger scale is required to confirm these findings.

- Integrated System Testing: Testing on the DM1200 WTP HLW Pilot Melter system provides data from a one-third scale system with a prototypical feed delivery system and off-gas treatment train. Such testing is necessary to evaluate potential interactive effects on system operation arising from implementation of the enhancement strategies and to provide data on the performance of each unit operation, input for flow-sheet models and regulatory requirements, and information of recycle streams.

- Longer-Duration Testing: After validation at larger scale, the duration of testing should be extended in order to address and quantify any chronic issues, such as the slow accumulation of crystals in the melter cavity, any degradation in the ability to discharge glass, and effects on off-gas line plugging. Settling of bismuth and nickel during idling periods is of particular concern for the high bismuth HLW waste streams.

- $\quad$ Other WTP High Bismuth HLW Waste Types: The present testing was based on a single high bismuth HLW composition from the Hanford tanks. Subsequent work should extend these results to address the full range of high bismuth HLW feeds expected to be processed at the WTP. 
- Throughput: A key risk area addressed in the present work relates to the strong dependence of glass production rates on waste composition and the extent to which shortfalls in processing rate can be mitigated through reformulation of the baseline glass compositions. The extent of this variation and potential shortfall across the full spectrum of HLW waste types needs to be quantified in order to accurately project waste treatment rates. 


\section{SECTION 7.0 REFERENCES}

[1] "High Level Waste Vitrification System Improvements," K.S. Matlack, H. Gan, W. Gong, I.L. Pegg, C.C. Chapman and I. Joseph, VSL-07R1010-1, Rev. 0, Vitreous State Laboratory, The Catholic University of America, Washington, DC, 4/16/07.

[2] "Tests with High-Bismuth HLW Glasses," K.S. Matlack, H. Gan, W. K. Kot, M. Chaudhuri, R. K. Mohr, D. A. McKeown, T. Bardakci, W. Gong, A. C. Buechele, and I.L. Pegg, Final Report, VSL-10R1780-1, Rev. 0, Vitreous State Laboratory, The Catholic University of America, Washington, DC, 12/13/10.

[3] "Melter Testing of New High Bismuth HLW Formulations," W.K. Kot, H. Gan, K.S. Matlack, and I.L. Pegg, Test Plan, VSL-12T2770-1, Rev. 0, Vitreous State Laboratory, The Catholic University of America, Washington, DC, 07/30/12.

[4] "HLW Glass Development Testing," Contract Number DE- AC27-07RV14884, Mod. 16, Task 1: Melter Testing of New High-Bi HLW Formulations, US Department of Energy, Office of River Protection, Richland, WA, 6/12/12.

[5] "Test and Evaluate High Level Waste (HLW) Vitrification System Improvements," Contract Number DE-AC27-06RV14790, US Department of Energy, Office of River Protection, Richland, WA, April, 2006.

[6] "Integrated DM1200 Melter Testing of Bubbler Configurations Using HLW AZ-101 Simulants," K.S. Matlack, W. Gong, T. Bardakci, N. D’Angelo, W. Lutze, R. A. Callow, M. Brandys, W.K. Kot, and I.L. Pegg, VSL-04R4800-4, Rev. 0, Vitreous State Laboratory, The Catholic University of America, Washington, DC, 10/5/04.

[7] "Glass Formulation and Testing with RPP-WTP HLW Simulants," W.K. Kot, and I.L. Pegg, VSL-01R2540-2, Rev. 0, Vitreous State Laboratory, The Catholic University of America, Washington, DC, 2/16/01.

[8] "Glass Formulation to Support Melter Runs with HLW Simulants," Final Report, W.K. Kot, K. Klatt, and I.L. Pegg, VSL-03R3760-2, Rev. 0, Vitreous State Laboratory, The Catholic University of America, Washington, DC, 8/8/03.

[9] "HLW Glass Formulation to Support C-106/AY-102 Actual Waste Testing," W.K. Kot and I.L. Pegg, VSL-04R4770-1, Rev. 0, Vitreous State Laboratory, The Catholic University of America, Washington, DC, 8/12/04.

[10] "Melter Tests with AZ-101 HLW Simulant Using a DuraMelter 100 Vitrification System," K.S. Matlack, W.K. Kot, and I.L. Pegg, VSL-01R10N0-1, Rev. 1, Vitreous State Laboratory, The Catholic University of America, Washington, DC, 2/25/01. 
[11] "DuraMelter 100 HLW Simulant Validation Tests with C-106/AY-102 Feeds," K.S. Matlack, W. Gong and I.L. Pegg, VSL-05R5710-1, Rev. 0, Vitreous State Laboratory, The Catholic University of America, Washington, DC, 6/2/05.

[12] "Integrated DM1200 Melter Testing of HLW C-106/AY-102 Composition Using Bubblers," K.S. Matlack, W. Gong, T. Bardakci, N. D’Angelo, W. Kot and I.L. Pegg, VSL-03R3800-1, Rev. 0, Vitreous State Laboratory, The Catholic University of America, Washington, DC, 9/15/03.

[13] "Integrated DM1200 Melter Testing of HLW C-104/AY-101 Compositions Using Bubblers," K.S. Matlack, W. Gong, T. Bardakci, N. D’Angelo, W. Kot and I.L. Pegg, VSL-03R3800-3, Rev. 0, Vitreous State Laboratory, The Catholic University of America, Washington, DC, 11/24/03.

[14] "DM1200 Tests with AZ-101 HLW Simulants," K.S. Matlack, W. Gong, T. Bardakci, N. D'Angelo, W.K. Kot, and I.L. Pegg, VSL-03R3800-4, Rev. 0, Vitreous State Laboratory, The Catholic University of America, Washington, DC, 2/17/04.

[15] "Start-Up and Commissioning Tests on the DM1200 HLW Pilot Melter System Using AZ-101 Waste Simulants," K.S. Matlack, M. Brandys, and I.L. Pegg, VSL-01R0100-2, Rev. 1, Vitreous State Laboratory, The Catholic University of America, Washington, DC, 10/31/01.

[16] "Tests on the DuraMelter 1200 HLW Pilot Melter System Using AZ-101 HLW Simulants," K.S. Matlack, W.K. Kot, T. Bardakci, T.R. Schatz, W. Gong, and I.L. Pegg, VSL-02R0100-2, Rev. 0, Vitreous State Laboratory, The Catholic University of America, Washington, DC, 6/11/02.

[17] "Integrated DM1200 Melter Testing of HLW AZ-102 Compositions Using Bubblers," K.S. Matlack, W. Gong, T. Bardakci, N. D’Angelo, W. Kot and I.L. Pegg, VSL03R3800-2, Rev. 0, Vitreous State Laboratory, The Catholic University of America, Washington, DC, 9/24/03.

[18] "Integrated DM1200 Melter Testing of Redox Effects Using HLW AZ-101 and C-106/AY-102 Simulants," K.S. Matlack, W. Gong, T. Bardakci, N. D’Angelo, W. Lutze, P. M. Bizot, R. A. Callow, M. Brandys, W.K. Kot, and I.L. Pegg, VSL04R4800-1, Rev. 0, Vitreous State Laboratory, The Catholic University of America, Washington, DC, 5/6/04.

[19] "Integrated DM1200 Melter Testing Using AZ-102 and C-106/AY-102 HLW Simulants: HLW Simulant Verification," K.S. Matlack, W. Gong, T. Bardakci, N. D’Angelo, M. Brandys, W.K. Kot, and I.L. Pegg, VSL-05R5800-1, Rev. 0, Vitreous State Laboratory, The Catholic University of America, Washington, DC, 6/27/05. 
[21] "Small Scale Melter Testing of HLW Algorithm Glasses: Matrix 1 Tests," K.S. Matlack, W.K. Kot, W. Gong and I.L. Pegg, Final Report, VSL-07R1220-1, Rev. 0, Vitreous State Laboratory, The Catholic University of America, Washington, DC, 11/12/07.

[22] "Small Scale Melter Testing of HLW Algorithm Glasses: Matrix 2 Tests," K.S. Matlack, W.K. Kot, W. Gong and I.L. Pegg, Final Report, VSL-08R1220-1, Rev. 0, Vitreous State Laboratory, The Catholic University of America, Washington, DC, 6/27/08.

[23] "Technetium/Cesium Volatility in DM100 Tests Using HLW AZ-102 and LAW Sub-Envelope A1 Simulants," K.S. Matlack, W.K. Kot, and I.L. Pegg, Final Report, VSL-04R4710-1, Rev. 0, Vitreous State Laboratory, The Catholic University of America, Washington, DC, 9/28/04.

[24] "Effects of High Spinel and Chromium Oxide Crystal Contents on Simulated HLW Vitrification in DM100 Melter Tests," K.S. Matlack, W.K. Kot, W. Gong, W. Lutze, I Joseph, and I.L. Pegg, Final Report, VSL-09R1520-1, Rev. 0, Vitreous State Laboratory, The Catholic University of America, Washington, DC, 6/19/09.

[25] "Next Generation Advanced Joule-Heated Melter Bench Scale Testing," K.S. Matlack, W.K. Kot, I.L. Pegg, and I. Joseph, Final Report, VSL-11R2320-1, Rev. 0, Vitreous State Laboratory, The Catholic University of America, Washington, DC, 10/13/11.

[26] "Melt Rate Enhancement for High Aluminum HLW Glass Formulations," K.S. Matlack, H. Gan, M. Chaudhuri, W.K. Kot, W. Gong, T. Bardakci, and I.L. Pegg, Final Report, VSL-08R1360-1, Rev. 0, Vitreous State Laboratory, The Catholic University of America, Washington, DC, 12/19/08.

[27] "DM100 and DM1200 Melter Testing with High Waste Loading Glass Formulations for Hanford High-Aluminum HLW Streams," K.S. Matlack, H. Gan, M. Chaudhuri, W.K Kot, W. Gong, T. Bardakci, I. Joseph, and I.L. Pegg, Final Report, VSL-10R1690-1, Rev. 0, Vitreous State Laboratory, The Catholic University of America, Washington, DC, 8/16/10.

[28] "Melter Throughput Enhancements for High-Iron HLW," K.S. Matlack, H. Gan, M. Chaudhuri, W.K. Kot, and I.L. Pegg, Final Report, VSL-12R2490-1, Rev. 0, Vitreous State Laboratory, The Catholic University of America, Washington, DC, 05/31/12.

[29] "HLW Enhancement Tests on the DuraMelter"M 10 with Hanford AZ-102 Tank Waste Simulants," K.S. Matlack, W.K. Kot, H. Gan, R.K. Mohr, W. Gong, and I.L. Pegg, Final Report, VSL-06R5260-1, Rev. 0, Vitreous State Laboratory, The Catholic University of America, Washington, DC, 02/28/06.

[30] "Quality Assurance Project Plan for ORP/ RPP-WTP Support Activities Conducted by VSL," Vitreous State Laboratory, QAPP-ORP, Rev. 3, Vitreous State Laboratory, The Catholic University of America, Washington, DC, 10/22/12. 
[31] "Master List of Controlled VSL Manuals and Standard Operating Procedures in Use," QA-MLCP, Rev. 90, Vitreous State Laboratory, The Catholic University of America, Washington, DC, 12/3/12.

[32] “Container Centerline Cooling Data, Revision 1" RPP-WTP Memorandum, L. Petkus to C. Musick, CCN\# 074851, 10/29/03.

[33] "Round Robin Testing of a Reference Glass for Low-Activity Waste Forms," W.L. Ebert and S.F. Wolf, Department of Energy report ANL-99/22, Argonne National Laboratory, Argonne, IL, 1999.

[34] "Characterization of the Defense Waste Processing Facility (DWPF) Environmental Assessment (EA) Glass Standard Reference Material," C.M. Jantzen, N.E. Bibler, D.C. Beam, C.L. Crawford and M.A. Pickett, WSRC-TR-92-346, Westinghouse Savannah River Company, Aiken, SC, June, 1993.

[35] "New Delisting Limits for Arsenic and Chrome," D. Blumenkranz, e-mail message to J. Westsik, CCN 069211, River Protection Project, Waste Treatment Plant, Richland, WA. 9/15/03.

[36] "Data Quality Objectives Process in Support of LDR/Delisting at the WTP," J. Cook and D. Blumenkranz, 24590-WTP-RPT-ENV-01-012, Rev. 2, River Protection Project, Waste Treatment Plant, Richland, WA, 3/26/03. 
Table 2.1. Oxide Compositions of Limiting Waste Streams.

\begin{tabular}{|c|c|c|c|c|}
\hline $\begin{array}{c}\text { Waste } \\
\text { Component }\end{array}$ & $\begin{array}{l}\text { Bi Limited } \\
\text { Glass }\end{array}$ & $\begin{array}{l}\text { Cr Limited } \\
\text { Glass }\end{array}$ & $\begin{array}{l}\text { Al Limited } \\
\text { Glass }\end{array}$ & $\begin{array}{c}\mathrm{Al} \text { and Na } \\
\text { Limited Glass }\end{array}$ \\
\hline $\mathrm{Al}_{2} \mathrm{O}_{3}$ & $22.45 \%$ & $25.53 \%$ & $49.21 \%$ & $43.30 \%$ \\
\hline $\mathrm{B}_{2} \mathrm{O}_{3}$ & $0.58 \%$ & $0.53 \%$ & $0.39 \%$ & $0.74 \%$ \\
\hline $\mathrm{CaO}$ & $1.61 \%$ & $2.47 \%$ & $2.21 \%$ & $1.47 \%$ \\
\hline $\mathrm{Fe}_{2} \mathrm{O}_{3}$ & $13.40 \%$ & $13.13 \%$ & $12.11 \%$ & $5.71 \%$ \\
\hline $\mathrm{Li}_{2} \mathrm{O}$ & $0.31 \%$ & $0.36 \%$ & $0.35 \%$ & $0.15 \%$ \\
\hline $\mathrm{MgO}$ & $0.82 \%$ & $0.16 \%$ & $0.24 \%$ & $0.44 \%$ \\
\hline $\mathrm{Na}_{2} \mathrm{O}$ & $12.97 \%$ & $20.09 \%$ & $7.35 \%$ & $25.79 \%$ \\
\hline $\mathrm{SiO}_{2}$ & $12.04 \%$ & $10.56 \%$ & $10.05 \%$ & $6.22 \%$ \\
\hline $\mathrm{TiO}_{2}$ & $0.30 \%$ & $0.01 \%$ & $0.02 \%$ & $0.35 \%$ \\
\hline $\mathrm{ZnO}$ & $0.31 \%$ & $0.25 \%$ & $0.17 \%$ & $0.36 \%$ \\
\hline $\mathrm{ZrO}_{2}$ & $0.40 \%$ & $0.11 \%$ & $0.81 \%$ & $0.25 \%$ \\
\hline $\mathrm{SO}_{3}$ & $0.91 \%$ & $1.52 \%$ & $0.41 \%$ & $0.44 \%$ \\
\hline $\mathrm{Bi}_{2} \mathrm{O}_{3}$ & $12.91 \%$ & $7.29 \%$ & $2.35 \%$ & $2.35 \%$ \\
\hline $\mathrm{ThO}_{2}$ & $0.25 \%$ & $0.04 \%$ & $0.37 \%$ & $0.04 \%$ \\
\hline $\mathrm{Cr}_{2} \mathrm{O}_{3}$ & $1.00 \%$ & $3.07 \%$ & $1.07 \%$ & $1.44 \%$ \\
\hline $\mathrm{K}_{2} \mathrm{O}$ & $0.89 \%$ & $0.37 \%$ & $0.29 \%$ & $1.34 \%$ \\
\hline $\mathrm{U}_{3} \mathrm{O}_{8}$ & $3.48 \%$ & $7.59 \%$ & $7.25 \%$ & $4.58 \%$ \\
\hline $\mathrm{BaO}$ & $0.02 \%$ & $0.03 \%$ & $0.11 \%$ & $0.06 \%$ \\
\hline $\mathrm{CdO}$ & $0.00 \%$ & $0.01 \%$ & $0.05 \%$ & $0.02 \%$ \\
\hline $\mathrm{NiO}$ & $3.71 \%$ & $1.06 \%$ & $0.82 \%$ & $0.20 \%$ \\
\hline $\mathrm{PbO}$ & $0.48 \%$ & $0.48 \%$ & $0.84 \%$ & $0.18 \%$ \\
\hline $\mathrm{P}_{2} \mathrm{O}_{5}$ & $9.60 \%$ & $3.34 \%$ & $2.16 \%$ & $4.10 \%$ \\
\hline F- & $1.58 \%$ & $2.00 \%$ & $1.37 \%$ & $0.46 \%$ \\
\hline Total & $100.0 \%$ & $100.0 \%$ & $100.0 \%$ & $100.0 \%$ \\
\hline
\end{tabular}


Table 2.2. Compositions of the Bi-Limited Waste (Oxide Basis) and the HLW Waste Simulant to Produce $100 \mathrm{~kg}$ of Waste Oxides (20 wt\% suspended solids).

\begin{tabular}{|c|c|c|c|}
\hline \multicolumn{2}{|c|}{ Bi-Limited Waste Composition } & \multicolumn{2}{|c|}{ Bi-Limited HLW Waste Simulant } \\
\hline Waste Oxide & Wt\% & Starting Materials & Target Weight (kg) ${ }^{1}$ \\
\hline $\mathrm{Al}_{2} \mathrm{O}_{3}$ & $22.45 \%$ & $\mathrm{Al}_{2} \mathrm{O}_{3}$ & 22.677 \\
\hline $\mathrm{B}_{2} \mathrm{O}_{3}$ & $0.58 \%$ & $\mathrm{H}_{3} \mathrm{BO}_{3}$ & 1.041 \\
\hline $\mathrm{CaO}$ & $1.61 \%$ & $\mathrm{CaO}$ & 1.643 \\
\hline $\mathrm{Fe}_{2} \mathrm{O}_{3}$ & $13.40 \%$ & $\mathrm{Fe}(\mathrm{OH})_{3}(13 \%$ Slurry $)$ & 26.752 \\
\hline $\mathrm{Li}_{2} \mathrm{O}$ & $0.31 \%$ & $\mathrm{Li}_{2} \mathrm{CO}_{3}$ & 0.786 \\
\hline $\mathrm{MgO}$ & $0.82 \%$ & $\mathrm{MgO}$ & 0.863 \\
\hline $\mathrm{Na}_{2} \mathrm{O}$ & $12.97 \%$ & $\mathrm{NaOH}$ & 11.108 \\
\hline $\mathrm{SiO}_{2}$ & $12.04 \%$ & $\mathrm{SiO}_{2}$ & 12.162 \\
\hline $\mathrm{TiO}_{2}$ & $0.30 \%$ & $\mathrm{TiO}_{2}$ & 0.303 \\
\hline $\mathrm{ZnO}$ & $0.31 \%$ & $\mathrm{ZnO}$ & 0.313 \\
\hline $\mathrm{ZrO}_{2}$ & $0.40 \%$ & $\mathrm{Zr}(\mathrm{OH})_{4} \cdot x \mathrm{H}_{2} \mathrm{O}$ & 1.034 \\
\hline $\mathrm{SO}_{3}$ & $0.91 \%$ & $\mathrm{Na}_{2} \mathrm{SO}_{4}$ & 1.632 \\
\hline $\mathrm{Bi}_{2} \mathrm{O}_{3}$ & $12.91 \%$ & $\mathrm{Bi}_{2} \mathrm{O}_{3}$ & 13.040 \\
\hline $\mathrm{ThO}_{2}$ & $0.25 \%$ & \multicolumn{2}{|c|}{ Omitted } \\
\hline $\mathrm{Cr}_{2} \mathrm{O}_{3}$ & $1.00 \%$ & $\mathrm{Cr}_{2} \mathrm{O}_{3} \cdot 1.5 \mathrm{H}_{2} \mathrm{O}$ & 1.190 \\
\hline $\mathrm{K}_{2} \mathrm{O}$ & $0.89 \%$ & $\mathrm{KNO}_{3}$ & 1.940 \\
\hline $\mathrm{U}_{3} \mathrm{O}_{8}$ & $3.48 \%$ & \multicolumn{2}{|c|}{ Omitted } \\
\hline $\mathrm{BaO}$ & $0.02 \%$ & $\mathrm{BaCO}_{3}$ & 0.026 \\
\hline $\mathrm{CdO}$ & $0.00 \%$ & $\mathrm{CdO}$ & 0.000 \\
\hline $\mathrm{NiO}$ & $3.71 \%$ & $\mathrm{Ni}(\mathrm{OH})_{2}$ & 4.771 \\
\hline $\mathrm{PbO}$ & $0.48 \%$ & $\mathrm{PbO}$ & 0.485 \\
\hline $\mathrm{P}_{2} \mathrm{O}_{5}$ & $9.60 \%$ & $\mathrm{FePO}_{4} \cdot x \mathrm{H}_{2} \mathrm{O}$ & 25.501 \\
\hline $\mathrm{F}$ & $1.58 \%$ & $\mathrm{NaF}$ & 3.510 \\
\hline Carbonate & $1.20^{2}$ & $\mathrm{Na}_{2} \mathrm{CO}_{3}$ & 1.011 \\
\hline Nitrite & 0.50 & $\mathrm{NaNO}_{2}$ & 0.769 \\
\hline Nitrate & 2.00 & $\mathrm{NaNO}_{3}$ & 1.141 \\
\hline Organic Carbon & 0.05 & $\mathrm{H}_{2} \mathrm{C}_{2} \mathrm{O}_{4} \cdot 2 \mathrm{H}_{2} \mathrm{O}$ & 0.264 \\
\hline- & - & Water & 353.500 \\
\hline TOTAL & $100.0 \%$ & TOTAL & $487.463^{3}$ \\
\hline
\end{tabular}

${ }^{1}$ Target weights adjusted for assay information of starting materials

${ }^{2}$ Unit for volatile components is $\mathrm{g} / 100 \mathrm{~g}$ of waste oxide

${ }^{3}$ Total yields $100 \mathrm{~kg}$ waste oxides less amounts associated with omitted oxides

— Empty data field 
Table 2.3. Compositions and Properties of Bismuth Limited Waste and Glass Formulation, HLW-Bi-F3 at 50\% Waste Loading Used in Melter Tests (wt\%).

\begin{tabular}{|c|c|c|c|c|}
\hline- & $\begin{array}{c}\text { Bi-Limited } \\
\text { Waste* }\end{array}$ & Waste in Glass & $\begin{array}{c}\text { Glass Forming } \\
\text { Additives }\end{array}$ & $\begin{array}{c}\text { Target Glass } \\
\text { HLW-Bi-F3 }\end{array}$ \\
\hline $\mathrm{Al}_{2} \mathrm{O}_{3}$ & 23.31 & 11.66 & - & 11.66 \\
\hline $\mathrm{B}_{2} \mathrm{O}_{3}$ & 0.60 & 0.30 & 10.00 & 10.30 \\
\hline $\mathrm{BaO}$ & 0.02 & 0.01 & - & 0.01 \\
\hline $\mathrm{Bi}_{2} \mathrm{O}_{3}$ & 13.41 & 6.71 & - & 6.71 \\
\hline $\mathrm{CaO}$ & 1.67 & 0.84 & - & 0.84 \\
\hline $\mathrm{Cr}_{2} \mathrm{O}_{3}$ & 1.04 & 0.52 & - & 0.52 \\
\hline $\mathrm{F}$ & 1.64 & 0.82 & - & 0.82 \\
\hline $\mathrm{Fe}_{2} \mathrm{O}_{3}$ & 13.92 & 6.96 & - & 6.96 \\
\hline $\mathrm{K}_{2} \mathrm{O}$ & 0.92 & 0.46 & - & 0.46 \\
\hline $\mathrm{Li}_{2} \mathrm{O}$ & 0.32 & 0.16 & - & 0.16 \\
\hline $\mathrm{MgO}_{\mathrm{Na} O} \mathrm{O}$ & 0.85 & 0.43 & - & 0.43 \\
\hline $\mathrm{NiO}^{2}$ & 13.47 & 6.74 & 12.00 & 18.74 \\
\hline $\mathrm{P}_{2} \mathrm{O}_{5}$ & 3.85 & 1.93 & - & 1.93 \\
\hline $\mathrm{PbO}_{\mathrm{SiO}}$ & 9.97 & 4.99 & - & 4.99 \\
\hline $\mathrm{SiO}_{2}$ & 0.50 & 0.25 & - & 0.25 \\
\hline $\mathrm{SO}{ }_{3}$ & 0.31 & 6.26 & 28.00 & 34.26 \\
\hline $\mathrm{ZnO}$ & 0.95 & 0.16 & - & 0.16 \\
\hline $\mathrm{ZrO}_{2}$ & 0.32 & 0.48 & - & 0.48 \\
\hline $\mathrm{Sum}$ & 0.42 & 0.16 & - & 0.16 \\
\hline$* \mathrm{Renormalized} \mathrm{from} \mathrm{Ref} \cdot[5]$ after removal of radioactive components & 0.21 \\
\hline
\end{tabular}

* Renormalized from Ref. [5] after removal of radioactive components

\begin{tabular}{|c|c|c|c|}
\hline \multicolumn{3}{|c|}{ Viscosity @1150º, P } & 47.36 \\
\hline \multicolumn{3}{|c|}{ Conductivity @1150º, S/cm } & 0.43 \\
\hline \multicolumn{3}{|c|}{ Crystal Content, As Melted } & Trace \\
\hline \multicolumn{3}{|c|}{ Crystal Content, $72 \mathrm{hr}$ at $950^{\circ} \mathrm{C}$} & $\sim 1.0 \mathrm{vol} \%$ \\
\hline \multicolumn{3}{|c|}{ TCLP } & Pass \\
\hline \multirow{4}{*}{ PCT, g/L } & - & DWPF-EA & HLW-Bi-F3 \\
\hline & B & 16.7 & 0.917 \\
\hline & $\mathrm{Li}$ & 9.6 & 0.323 \\
\hline & $\mathrm{Na}$ & 13.3 & 0.812 \\
\hline
\end{tabular}

- Empty data field 
Table 2.4. Compositions and Properties of Bismuth Limited Waste and Glass Formulation, HLW-Bi-F9 at 50\% Waste Loading Used in Melter Tests (wt\%).

\begin{tabular}{|c|c|c|c|c|}
\hline- & $\begin{array}{c}\text { Bi-Limited } \\
\text { Waste* }\end{array}$ & Waste in Glass & $\begin{array}{c}\text { Glass Forming } \\
\text { Additives }\end{array}$ & $\begin{array}{c}\text { Target Glass } \\
\text { HLW-Bi-F9 }\end{array}$ \\
\hline $\mathrm{Al}_{2} \mathrm{O}_{3}$ & 23.31 & 11.66 & 5.00 & 16.66 \\
\hline $\mathrm{B}_{2} \mathrm{O}_{3}$ & 0.60 & 0.30 & 16.00 & 16.30 \\
\hline $\mathrm{BaO}$ & 0.02 & 0.01 & - & 0.01 \\
\hline $\mathrm{Bi}_{2} \mathrm{O}_{3}$ & 13.41 & 6.71 & - & 6.71 \\
\hline $\mathrm{CaO}$ & 1.67 & 0.84 & - & 0.84 \\
\hline $\mathrm{Cr}_{2} \mathrm{O}_{3}$ & 1.04 & 0.52 & - & 0.52 \\
\hline $\mathrm{F}$ & 1.64 & 0.82 & - & 0.82 \\
\hline $\mathrm{Fe}_{2} \mathrm{O}_{3}$ & 13.92 & 6.96 & - & 6.96 \\
\hline $\mathrm{K}_{2} \mathrm{O}$ & 0.92 & 0.46 & - & 0.46 \\
\hline $\mathrm{Li}_{2} \mathrm{O}$ & 0.32 & 0.16 & 5.00 & 5.16 \\
\hline $\mathrm{MgO}$ & 0.85 & 0.43 & - & 0.43 \\
\hline $\mathrm{Na}_{2} \mathrm{O}$ & 13.47 & 6.74 & 1.00 & 7.74 \\
\hline $\mathrm{NiO}^{2}$ & 3.85 & 1.93 & - & 1.93 \\
\hline $\mathrm{P}_{2} \mathrm{O}_{5}$ & 9.97 & 4.99 & - & 4.99 \\
\hline $\mathrm{PbO}^{3}$ & 0.50 & 0.25 & - & 0.25 \\
\hline $\mathrm{SiO}_{2}$ & 12.51 & 6.26 & 23.00 & 29.26 \\
\hline $\mathrm{TiO}_{2}$ & 0.31 & 0.16 & - & 0.16 \\
\hline $\mathrm{SO}_{3}$ & 0.95 & 0.48 & - & 0.48 \\
\hline $\mathrm{ZnO}_{\mathrm{ZrO}}$ & 0.32 & 0.16 & - & 0.16 \\
\hline $\mathrm{Sum}_{2 n}$ & 0.42 & 0.21 & - & 0.21 \\
\hline $\mathrm{Rn}_{2}$ & 100 & 50 & 50 & 100 \\
\hline
\end{tabular}

* Renormalized from Ref. [5] after removal of radioactive components

\begin{tabular}{|c|c|c|c|}
\hline \multicolumn{3}{|c|}{ Viscosity @1150, P } & 18.52 \\
\hline \multicolumn{3}{|c|}{ Conductivity @1150º, S/cm } & 0.39 \\
\hline \multicolumn{3}{|c|}{ Crystal Content, As Melted } & Trace \\
\hline \multicolumn{3}{|c|}{ Crystal Content, $72 \mathrm{hr}$ at $950^{\circ} \mathrm{C}$} & $\sim 2.2$ vol\% \\
\hline \multicolumn{3}{|c|}{ TCLP } & Pass \\
\hline \multirow{4}{*}{ PCT, g/L } & - & DWPF-EA & HLW-Bi-F9 \\
\hline & B & 16.7 & 3.112 \\
\hline & $\mathrm{Li}$ & 9.6 & 1.901 \\
\hline & $\mathrm{Na}$ & 13.3 & 1.309 \\
\hline
\end{tabular}

- Empty data field 
Table 2.5. Composition of Melter Feed to Produce $100 \mathrm{~kg}$ of Target Glass HLW-Bi-F3 (Glass Yield = $500 \mathrm{~g} / \mathrm{L}$ Feed) from the Bi-Limited Waste Simulant.

\begin{tabular}{|c|c|c|c|}
\hline \multicolumn{2}{|c|}{ Bi-Limited HLW Simulant } & \multicolumn{2}{|c|}{ Glass-Forming Additives } \\
\hline Starting Materials & Target Weight (kg) $)^{(1)}$ & Starting Materials & Target Weight (kg) $)^{(1)}$ \\
\hline $\mathrm{Al}_{2} \mathrm{O}_{3}$ & 11.773 & & \\
\hline $\mathrm{H}_{3} \mathrm{BO}_{3}$ & 0.538 & $\mathrm{Na}_{2} \mathrm{~B}_{4} \mathrm{O}_{7 .} 10 \mathrm{H}_{2} \mathrm{O}$ & 27.666 \\
\hline $\mathrm{BaCO}_{3}$ & 0.013 & & \\
\hline $\mathrm{Bi}_{2} \mathrm{O}_{3}$ & 6.773 & & \\
\hline $\mathrm{CaO}$ & 0.852 & & \\
\hline $\mathrm{Cr}_{2} \mathrm{O}_{3}$ & 0.531 & & \\
\hline $\mathrm{NaF}$ & 1.822 & & \\
\hline $\mathrm{Fe}(\mathrm{OH})_{3}(13 \%$ Slurry $)$ & 13.913 & & \\
\hline $\mathrm{KNO}_{3}$ & 1.003 & & \\
\hline $\mathrm{Li}_{2} \mathrm{CO}_{3}$ & 0.406 & & \\
\hline $\mathrm{MgO}$ & 0.438 & & \\
\hline $\mathrm{NaOH}$ & 5.828 & $\mathrm{Na}_{2} \mathrm{CO}_{3}$ & 12.823 \\
\hline $\mathrm{Ni}(\mathrm{OH})_{2}$ & 2.476 & & \\
\hline $\mathrm{FePO}_{4} \cdot x \mathrm{H}_{2} \mathrm{O}$ & 13.242 & & \\
\hline $\mathrm{PbO}$ & 0.253 & & \\
\hline $\mathrm{Na}_{2} \mathrm{SO}_{4}$ & 0.852 & & \\
\hline $\mathrm{SiO}_{2}$ & 6.318 & $\mathrm{SiO}_{2}$ & 28.283 \\
\hline $\mathrm{TiO}_{2}$ & 0.157 & & \\
\hline $\mathrm{ZnO}$ & 0.162 & & \\
\hline $\mathrm{Zr}(\mathrm{OH})_{4} \cdot x \mathrm{H}_{2} \mathrm{O}$ & 0.543 & & \\
\hline $\mathrm{Na}_{2} \mathrm{CO}_{3}$ & 0.488 & & \\
\hline $\mathrm{NaNO}_{2}$ & 0.385 & & \\
\hline $\mathrm{NaNO}_{3}$ & 0.544 & & \\
\hline $\mathrm{H}_{2} \mathrm{C}_{2} \mathrm{O}_{4} \cdot 2 \mathrm{H}_{2} \mathrm{O}$ & 0.132 & & \\
\hline $\mathrm{H}_{2} \mathrm{O}$ & 142.206 & & \\
\hline \multirow[t]{2}{*}{ Simulant TOTAL } & 211.65 & Additives TOTAL & 68.772 \\
\hline & & Feed TOTAL & 280.42 \\
\hline
\end{tabular}

(1) Target weights adjusted for assay information of starting materials. 
Table 2.6. Composition of Melter Feed to Produce $100 \mathrm{~kg}$ of Target Glass HLW-Bi-F9 (Glass Yield = $500 \mathrm{~g} / \mathrm{L}$ Feed) from the Bi-Limited Waste Simulant.

\begin{tabular}{|c|c|c|c|}
\hline \multicolumn{2}{|c|}{ Bi-Limited HLW Simulant } & \multicolumn{2}{|c|}{ Glass-Forming Additives } \\
\hline Starting Materials & Target Weight (kg) ${ }^{(1)}$ & Starting Materials & Target Weight (kg) ${ }^{(1)}$ \\
\hline $\mathrm{Al}_{2} \mathrm{O}_{3}$ & 11.773 & Kyanite & 7.947 \\
\hline $\mathrm{H}_{3} \mathrm{BO}_{3}$ & 0.538 & $\mathrm{H}_{3} \mathrm{BO}_{3}$. & 28.419 \\
\hline $\mathrm{BaCO}_{3}$ & 0.013 & & \\
\hline $\mathrm{Bi}_{2} \mathrm{O}_{3}$ & 6.773 & & \\
\hline $\mathrm{CaO}$ & 0.852 & & \\
\hline $\mathrm{Cr}_{2} \mathrm{O}_{3}$ & 0.531 & & \\
\hline $\mathrm{NaF}$ & 1.822 & & \\
\hline $\mathrm{Fe}(\mathrm{OH})_{3}(13 \%$ Slurry $)$ & 13.913 & & \\
\hline $\mathrm{KNO}_{3}$ & 1.003 & & \\
\hline $\mathrm{Li}_{2} \mathrm{CO}_{3}$ & 0.406 & $\mathrm{Li}_{2} \mathrm{CO}_{3}$ & 12.363 \\
\hline $\mathrm{MgO}$ & 0.438 & & \\
\hline $\mathrm{NaOH}$ & 5.828 & $\mathrm{Na}_{2} \mathrm{CO}_{3}$ & 1.710 \\
\hline $\mathrm{Ni}(\mathrm{OH})_{2}$ & 2.476 & & \\
\hline $\mathrm{FePO}_{4} \cdot x \mathrm{H}_{2} \mathrm{O}$ & 13.242 & & \\
\hline $\mathrm{PbO}$ & 0.253 & & \\
\hline $\mathrm{Na}_{2} \mathrm{SO}_{4}$ & 0.852 & & \\
\hline $\mathrm{SiO}_{2}$ & 6.318 & $\mathrm{SiO}_{2}$ & 20.554 \\
\hline $\mathrm{TiO}_{2}$ & 0.157 & & \\
\hline $\mathrm{ZnO}$ & 0.162 & & \\
\hline $\mathrm{Zr}(\mathrm{OH})_{4} \cdot x \mathrm{H}_{2} \mathrm{O}$ & 0.543 & & \\
\hline $\mathrm{Na}_{2} \mathrm{CO}_{3}$ & 0.488 & & \\
\hline $\mathrm{NaNO}_{2}$ & 0.385 & & \\
\hline $\mathrm{NaNO}_{3}$ & 0.544 & & \\
\hline $\mathrm{H}_{2} \mathrm{C}_{2} \mathrm{O}_{4} \cdot 2 \mathrm{H}_{2} \mathrm{O}$ & 0.132 & & \\
\hline $\mathrm{H}_{2} \mathrm{O}$ & 142.206 & & \\
\hline Simulant TOTAL & 211.65 & Additives TOTAL & 70.982 \\
\hline & & Feed TOTAL & 282.632 \\
\hline
\end{tabular}

(1) Target weights for pure chemicals and minerals thus will be adjusted for assay information of starting materials. 


\section{Table 3.1. Summary of Results from DM100 Tests with High Bismuth Waste and HLW-Bi-F3 Glass Composition.}

\begin{tabular}{|c|c|c|c|}
\hline \multicolumn{2}{|r|}{ Test } & $\begin{array}{c}\text { Test } 1 \\
\text { Optimized } \\
\text { Bubbling }\end{array}$ & $\begin{array}{c}\text { Test } 2 \\
\text { Fixed Bubbling } \\
(9 \mathrm{lpm})\end{array}$ \\
\hline \multirow{3}{*}{$\underset{\Xi}{g}$} & Feed Start & 8/20/12 10:05 & 8/22/12 14:05 \\
\hline & Feed End & 8/22/12 13:30 & 8/24/12 19:00 \\
\hline & Interval & $51.4 \mathrm{hr}$ & $52.9 \mathrm{hr}$ \\
\hline \multicolumn{2}{|c|}{ Water Feeding for Cold Cap } & $65 \mathrm{~min}$ & $0 \mathrm{~min}$ \\
\hline \multicolumn{2}{|r|}{ Slurry Feeding } & $50.4 \mathrm{hr}$ & $52.9 \mathrm{hr}$ \\
\hline \multicolumn{2}{|c|}{ Feeding Interruptions } & $13 \mathrm{~min}$ & $0 \mathrm{~min}$ \\
\hline \multicolumn{2}{|c|}{ Average Bubbling Rate } & 11.7 lpm & $8.8 \mathrm{lpm}$ \\
\hline \multirow{4}{*}{$\underset{\Phi}{\mathbb{\Xi}}$} & Used & $654.5 \mathrm{~kg}$ & $509.9 \mathrm{~kg}$ \\
\hline & \multirow{2}{*}{ Target Glass yield } & $500 \mathrm{~g} / \mathrm{l}$ & $500 \mathrm{~g} / \mathrm{l}$ \\
\hline & & $0.358 \mathrm{~kg} / \mathrm{kg}$ & $0.358 \mathrm{~kg} / \mathrm{kg}$ \\
\hline & Average Feed Rate & $13.0 \mathrm{~kg} / \mathrm{hr}$ & $9.6 \mathrm{~kg} / \mathrm{hr}$ \\
\hline \multirow{5}{*}{ 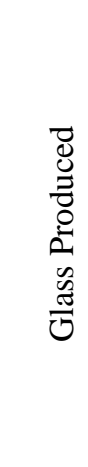 } & Poured & $225.4 \mathrm{~kg}$ & $189.4 \mathrm{~kg}$ \\
\hline & $\begin{array}{c}\text { Average Rate based } \\
\text { on glass poured }\end{array}$ & $994 \mathrm{~kg} / \mathrm{m}^{2} /$ day & $796 \mathrm{~kg} / \mathrm{m}^{2} /$ day \\
\hline & $\begin{array}{l}\text { Average Rate based } \\
\text { on feed consumed }\end{array}$ & $1034 \mathrm{~kg} / \mathrm{m}^{2} /$ day & $767 \mathrm{~kg} / \mathrm{m}^{2} /$ day \\
\hline & Steady State Rate ${ }^{*}$ & $1035 \mathrm{~kg} / \mathrm{m}^{2} /$ day & $770 \mathrm{~kg} / \mathrm{m}^{2} /$ day \\
\hline & Average Power Use & $\begin{array}{l}3.7 \mathrm{~kW} \mathrm{hr} / \mathrm{kg} \\
\text { glass }\end{array}$ & $\begin{array}{l}4.3 \mathrm{~kW} \mathrm{hr} / \mathrm{kg} \\
\text { glass }\end{array}$ \\
\hline
\end{tabular}

*: Rates estimated from feed data.

Note: Rates do not take into account the time for water feeding and cold cap burn-off. 
Table 3.2. Summary of Results from DM100 Tests with High Bismuth Waste and HLW-Bi-F9 Glass Composition.

\begin{tabular}{|c|c|c|c|}
\hline & Test & $\begin{array}{c}\text { Test } 3 \\
\text { Optimized } \\
\text { Bubbling }\end{array}$ & $\begin{array}{c}\text { Test } 4 \\
\text { Fixed Bubbling } \\
(9 \mathrm{lpm})\end{array}$ \\
\hline & Feed Start & 8/27/12 10:00 & 8/29/12 11:20 \\
\hline$\Xi$ & Feed End & 8/29/12 11:00 & 8/31/12 13:30 \\
\hline & Interval & $49.0 \mathrm{hr}$ & $50.2 \mathrm{hr}$ \\
\hline Wate & Feeding for Cold Cap & $60 \mathrm{~min}$ & $0 \mathrm{~min}$ \\
\hline & Slurry Feeding & $48.0 \mathrm{hr}$ & $50.2 \mathrm{hr}$ \\
\hline & ding Interruptions & $19 \mathrm{~min}$ & $10 \mathrm{~min}$ \\
\hline Av & age Bubbling Rate & $10.0 \mathrm{lpm}$ & $8.8 \mathrm{lpm}$ \\
\hline & Used & $1039.0 \mathrm{~kg}$ & $1026.7 \mathrm{~kg}$ \\
\hline $\bar{d}$ & $\pi$ & $500 \mathrm{~g} / \mathrm{l}$ & $500 \mathrm{~g} / \mathrm{l}$ \\
\hline & & $0.358 \mathrm{~kg} / \mathrm{kg}$ & $0.358 \mathrm{~kg} / \mathrm{kg}$ \\
\hline & Average Feed Rate & $21.6 \mathrm{~kg} / \mathrm{hr}$ & $20.5 \mathrm{~kg} / \mathrm{hr}$ \\
\hline & Poured & $350.0 \mathrm{~kg}$ & $352.4 \mathrm{~kg}$ \\
\hline$\Xi$ & $\begin{array}{c}\text { Average Rate based } \\
\text { on glass poured }\end{array}$ & $1620 \mathrm{~kg} / \mathrm{m}^{2} /$ day & $\begin{array}{c}1559.8 \\
\mathrm{~kg} / \mathrm{m}^{2} / \mathrm{day}\end{array}$ \\
\hline 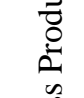 & $\begin{array}{l}\text { Average Rate based } \\
\text { on feed consumed }\end{array}$ & $1722 \mathrm{~kg} / \mathrm{m}^{2} /$ day & $1627 \mathrm{~kg} / \mathrm{m}^{2} /$ day \\
\hline$\frac{\pi}{0}$ & Steady State Rate ${ }^{*}$ & $2000 \mathrm{~kg} / \mathrm{m}^{2} /$ day & $1660 \mathrm{~kg} / \mathrm{m}^{2} /$ day \\
\hline & Average Power Use & $\begin{array}{l}3.3 \mathrm{~kW} \mathrm{hr} / \mathrm{kg} \\
\text { glass }\end{array}$ & $\begin{array}{l}3.4 \mathrm{~kW} \mathrm{hr} / \mathrm{kg} \\
\text { glass }\end{array}$ \\
\hline
\end{tabular}

*: Rates estimated from feed data.

Note: Rates do not take into account the time for water feeding and cold cap burn-off. 
Table 3.3. Steady-State Production Rates Achieved on the DM100 Melter with High Bismuth Waste; 500 g glass/liter and 50\% Waste Oxide Loading.

\begin{tabular}{|c|c|c|c|}
\hline Glass Composition & $\begin{array}{c}\text { Glass Temperature } \\
\left({ }^{\circ} \mathrm{C}\right)\end{array}$ & $\begin{array}{l}\text { Melt Pool Bubbling } \\
\text { (lpm) }\end{array}$ & $\begin{array}{c}\text { Glass Production Rate } \\
\left(\mathrm{kg} / \mathrm{m}^{2} / \text { day }\right)\end{array}$ \\
\hline \multirow{2}{*}{ HLW-Bi-F3 } & 1150 & Optimized, 11.7 & 1035 \\
\hline & 1150 & 8.8 & 770 \\
\hline \multirow{2}{*}{ HLW-Bi-F9 } & 1150 & Optimized, 10.0 & 2000 \\
\hline & 1150 & 8.8 & 1660 \\
\hline \multirow{4}{*}{ HLW-E-Bi-6 [1] } & 1175 & Optimized, 14.1 & 1200 \\
\hline & 1175 & 9.0 & 1000 \\
\hline & 1150 & 9.0 & 830 \\
\hline & 1150 & Optimized & $1100 *$ \\
\hline
\end{tabular}

* - Value determined during melt pool turnover prior to current tests. 
Table 3.4. Summary of Measured DM100 Parameters while Processing the HLW-Bi-F3 Glass Composition.

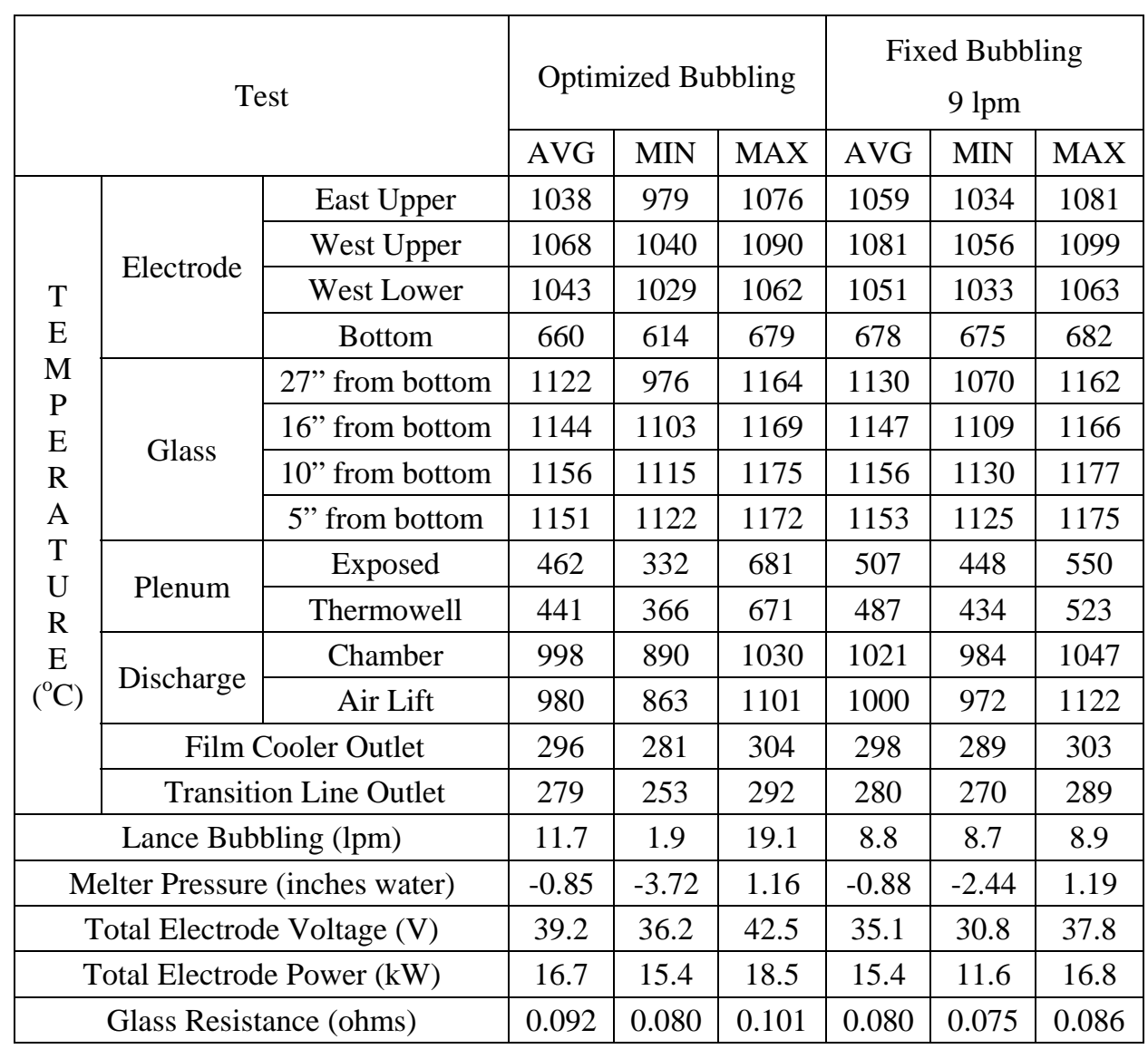


Table 3.5. Summary of Measured DM100 Parameters while Processing the HLW-Bi-F9 Glass Composition.

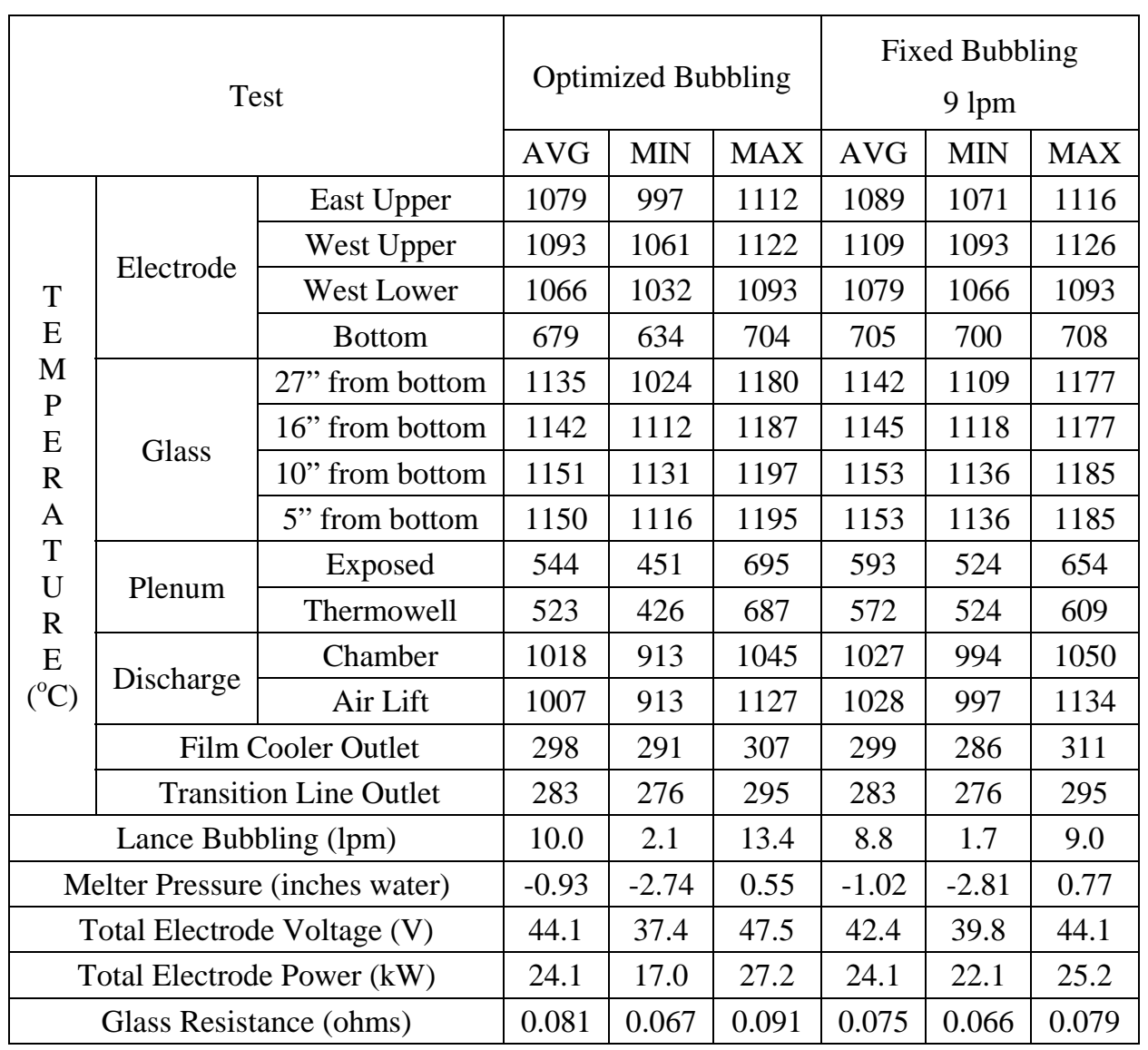


ORP-56288 Rev. 0

The Catholic University of America

Vitreous State Laboratory
Melter Testing of New High Bismuth HLW Formulations

Final Report, VSL-13R2770-1, Rev. 0

Table 4.1. Characteristics of Melter Feed Samples with High Bismuth Waste.

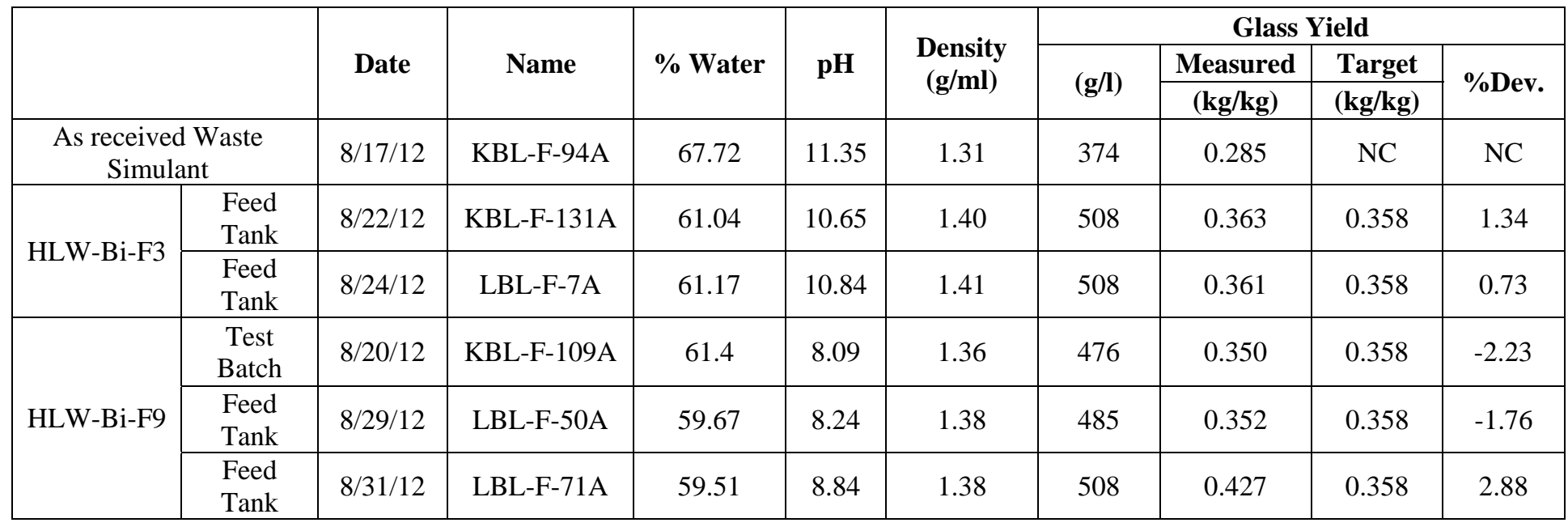

NC - Not calculated 
ORP-56288 Rev. 0

The Catholic University of America

Vitreous State Laboratory
Melter Testing of New High Bismuth HLW Formulations

Final Report, VSL-13R2770-1, Rev. 0

Table 4.2. XRF Analyzed Compositions of Vitrified Melter Feed Samples (wt\%).

\begin{tabular}{|c|c|c|c|c|c|c|c|}
\hline \multirow{2}{*}{ Constituent } & \multirow{2}{*}{$\begin{array}{c}\begin{array}{c}\text { Bi Limited } \\
\text { Waste }\end{array} \\
\text { Target }\end{array}$} & \multirow{2}{*}{\begin{tabular}{|c|}
$\begin{array}{c}\text { As Received } \\
\text { Waste Simulant }\end{array}$ \\
KBL-F-94A \\
\end{tabular}} & \multicolumn{5}{|c|}{$\begin{array}{c}\text { HLW-Bi-F3 } \\
\text { (Tests } 1 \text { and 2) }\end{array}$} \\
\hline & & & Target & KBL-F-131A & LBL-F-7A & Average & \% Dev. \\
\hline $\mathrm{Al}_{2} \mathrm{O}_{3}$ & 23.31 & 21.58 & 11.65 & 11.95 & 12.06 & 12.01 & 3.02 \\
\hline $\mathrm{B}_{2} \mathrm{O}_{3}$ & 0.60 & $0.60^{*}$ & 10.29 & $9.26^{*}$ & $9.10^{*}$ & 9.18 & -10.83 \\
\hline $\mathrm{BaO}$ & 0.02 & 0.00 & 0.01 & 0.02 & $<0.01$ & 0.01 & $\mathrm{NC}$ \\
\hline $\mathrm{Bi}_{2} \mathrm{O}_{3}$ & 13.41 & 14.74 & 6.71 & 7.55 & 6.76 & 7.16 & 6.74 \\
\hline $\mathrm{CaO}$ & 1.67 & 1.58 & 0.84 & 0.84 & 0.79 & 0.82 & $\mathrm{NC}$ \\
\hline $\mathrm{CdO}$ & $\S$ & $<0.01$ & $\S$ & $<0.01$ & $<0.01$ & $<0.01$ & $\mathrm{NC}$ \\
\hline $\mathrm{Cl}$ & $\S$ & $<0.01$ & $\S$ & 0.01 & 0.02 & 0.01 & $\mathrm{NC}$ \\
\hline $\mathrm{Cr}_{2} \mathrm{O}_{3}$ & 1.04 & 1.12 & 0.52 & 0.57 & 0.51 & 0.54 & NC \\
\hline $\mathrm{F}$ & 1.64 & $1.64^{\#}$ & 0.82 & $0.82^{\#}$ & $0.82^{\#}$ & 0.82 & $\mathrm{NC}$ \\
\hline $\mathrm{Fe}_{2} \mathrm{O}_{3}$ & 13.92 & 14.21 & 6.96 & 7.39 & 6.74 & 7.06 & 1.55 \\
\hline $\mathrm{K}_{2} \mathrm{O}$ & 0.92 & 0.87 & 0.46 & 0.48 & 0.46 & 0.47 & NC \\
\hline $\mathrm{Li}_{2} \mathrm{O}$ & 0.32 & $0.34^{*}$ & 0.16 & $0.20^{*}$ & $0.19^{*}$ & 0.20 & $\mathrm{NC}$ \\
\hline $\mathrm{MgO}$ & 0.85 & 0.23 & 0.43 & 0.46 & 0.55 & 0.51 & $\mathrm{NC}$ \\
\hline $\mathrm{MnO}$ & $\S$ & $<0.01$ & $\S$ & 0.03 & 0.02 & 0.02 & NC \\
\hline $\mathrm{Na}_{2} \mathrm{O}$ & 13.47 & 13.22 & 18.73 & 17.43 & 19.97 & 18.70 & -0.19 \\
\hline $\mathrm{NiO}$ & 3.85 & 4.41 & 1.93 & 2.31 & 2.12 & 2.21 & 14.79 \\
\hline $\mathrm{P}_{2} \mathrm{O}_{5}$ & 9.97 & 10.48 & 4.99 & 5.45 & 5.37 & 5.41 & 8.44 \\
\hline $\mathrm{PbO}$ & 0.50 & 0.50 & 0.25 & 0.26 & 0.23 & 0.24 & $\mathrm{NC}$ \\
\hline $\mathrm{SiO}_{2}$ & 12.51 & 12.54 & 34.24 & 33.88 & 33.27 & 33.57 & -1.95 \\
\hline $\mathrm{SO}_{3}$ & 0.95 & 0.98 & 0.48 & 0.42 & 0.44 & 0.43 & NC \\
\hline $\mathrm{SrO}$ & $\S$ & $<0.01$ & $\S$ & 0.01 & 0.01 & 0.01 & $\mathrm{NC}$ \\
\hline $\mathrm{TiO}_{2}$ & 0.31 & 0.31 & 0.16 & 0.20 & 0.16 & 0.18 & NC \\
\hline $\mathrm{ZnO}$ & 0.32 & 0.32 & 0.16 & 0.16 & 0.15 & 0.16 & NC \\
\hline $\mathrm{ZrO}_{2}$ & 0.42 & 0.33 & 0.21 & 0.29 & 0.26 & 0.28 & $\mathrm{NC}$ \\
\hline Sum & 100.00 & 100.00 & 100.00 & 100.00 & 100.00 & 100.00 & $\mathrm{NC}$ \\
\hline
\end{tabular}


ORP-56288 Rev. 0

The Catholic University of America

Vitreous State Laboratory
Melter Testing of New High Bismuth HLW Formulations

Final Report, VSL-13R2770-1, Rev. 0

Table 4.2. XRF Analyzed Compositions for the Vitrified Melter Feed Samples (wt\%) (continued).

\begin{tabular}{|c|c|c|c|c|c|c|}
\hline \multirow{2}{*}{ Constituent } & \multirow{2}{*}{ Target } & \multicolumn{5}{|c|}{$\begin{array}{c}\text { HLW-Bi-F9 } \\
\text { (Tests } 3 \text { and 4) }\end{array}$} \\
\hline & & KBL-F-109A & LBL-F-50A & LBL-F-71A & Average & \% Dev. \\
\hline $\mathrm{Al}_{2} \mathrm{O}_{3}$ & 16.65 & 15.81 & 15.76 & 15.54 & 15.70 & -5.99 \\
\hline $\mathrm{B}_{2} \mathrm{O}_{3}$ & 16.29 & $15.99^{*}$ & $15.83^{*}$ & $15.81^{*}$ & 15.88 & -2.90 \\
\hline $\mathrm{BaO}$ & 0.01 & $<0.01$ & $<0.01$ & $<0.01$ & $<0.01$ & $\mathrm{NC}$ \\
\hline $\mathrm{Bi}_{2} \mathrm{O}_{3}$ & 6.71 & 7.27 & 7.22 & 7.22 & 7.24 & 7.30 \\
\hline $\mathrm{CaO}$ & 0.84 & 0.81 & 0.79 & 0.77 & 0.79 & $\mathrm{NC}$ \\
\hline $\mathrm{CdO}$ & $\S$ & $<0.01$ & $<0.01$ & $<0.01$ & $<0.01$ & $\mathrm{NC}$ \\
\hline $\mathrm{Cl}$ & $\S$ & 0.01 & 0.01 & 0.01 & 0.01 & NC \\
\hline $\mathrm{Cr}_{2} \mathrm{O}_{3}$ & 0.52 & 0.50 & 0.46 & 0.52 & 0.49 & NC \\
\hline $\mathrm{F}$ & 0.82 & $0.82^{\#}$ & $0.82^{\#}$ & $0.82^{\#}$ & 0.82 & NC \\
\hline $\mathrm{Fe}_{2} \mathrm{O}_{3}$ & 6.96 & 7.09 & 6.79 & 6.88 & 6.92 & 0.49 \\
\hline $\mathrm{K}_{2} \mathrm{O}$ & 0.46 & 0.47 & 0.46 & 0.46 & 0.46 & $\mathrm{NC}$ \\
\hline $\mathrm{Li}_{2} \mathrm{O}$ & 5.16 & $5.04^{*}$ & $4.87^{*}$ & $4.92^{*}$ & 4.94 & -4.25 \\
\hline $\mathrm{MgO}$ & 0.43 & 0.26 & 0.38 & 0.33 & 0.33 & NC \\
\hline $\mathrm{MnO}$ & $\S$ & $<0.01$ & 0.02 & $<0.01$ & 0.01 & NC \\
\hline $\mathrm{Na}_{2} \mathrm{O}$ & 7.74 & 7.31 & 7.81 & 8.32 & 7.81 & -1.05 \\
\hline $\mathrm{NiO}$ & 1.93 & 2.09 & 1.92 & 2.08 & 2.03 & 4.77 \\
\hline $\mathrm{P}_{2} \mathrm{O}_{5}$ & 4.99 & 5.58 & 5.52 & 5.43 & 5.51 & 9.37 \\
\hline $\mathrm{PbO}$ & 0.25 & 0.25 & 0.61 & 0.38 & 0.42 & $\mathrm{NC}$ \\
\hline $\mathrm{SiO}_{2}$ & 29.25 & 29.57 & 29.58 & 29.37 & 29.51 & 0.89 \\
\hline $\mathrm{SO}_{3}$ & 0.48 & 0.50 & 0.49 & 0.50 & 0.49 & NC \\
\hline $\mathrm{SrO}$ & $\S$ & $<0.01$ & $<0.01$ & $<0.01$ & $<0.01$ & NC \\
\hline $\mathrm{TiO}_{2}$ & 0.16 & 0.31 & 0.30 & 0.28 & 0.30 & NC \\
\hline $\mathrm{ZnO}$ & 0.16 & 0.15 & 0.15 & 0.15 & 0.15 & NC \\
\hline $\mathrm{ZrO}_{2}$ & 0.21 & 0.17 & 0.19 & 0.18 & 0.18 & NC \\
\hline Sum & 100.00 & 100.00 & 100.00 & 100.00 & 100.00 & NC \\
\hline
\end{tabular}


ORP-56288 Rev. 0

The Catholic University of America

Vitreous State Laboratory
Melter Testing of New High Bismuth HLW Formulations

Final Report, VSL-13R2770-1, Rev. 0

Table 4.3. Listing of Glass Discharged and Masses.

\begin{tabular}{|c|c|c|c|c|}
\hline Test & Date & Name & Mass (kg) & Cumulative Mass (kg) \\
\hline \multirow{21}{*}{1} & \multirow{4}{*}{ 8/20/2012 } & KBL-G-108A & 9.92 & 9.92 \\
\hline & & KBL-G-109A & \multirow{2}{*}{20.30} & \multirow{2}{*}{30.22} \\
\hline & & KBL-G-109B & & \\
\hline & & KBL-G-111A & \multirow{2}{*}{19.58} & \multirow{2}{*}{49.80} \\
\hline & & KBL-G-114A & & \\
\hline & & KBL-G-114B & \multirow{2}{*}{19.34} & \multirow{2}{*}{69.14} \\
\hline & & KBL-G-114C & & \\
\hline & & KBL-G-115A & \multirow{2}{*}{21.24} & \multirow{2}{*}{90.38} \\
\hline & & KBL-G-115B & & \\
\hline & & KBL-G-115C & \multirow{2}{*}{21.92} & \multirow{2}{*}{112.30} \\
\hline & & KBL-G-115D & & \\
\hline & & KBL-G-119A & \multirow{2}{*}{24.40} & \multirow{2}{*}{136.70} \\
\hline & & KBL-G-119B & & \\
\hline & & KBL-G-123A & \multirow{2}{*}{19.72} & \multirow{2}{*}{156.42} \\
\hline & & KBL-G-123B & & \\
\hline & \multirow{8}{*}{$8 / 22 / 2012$} & KBL-G-124A & \multirow{2}{*}{21.08} & \multirow{2}{*}{177.50} \\
\hline & & KBL-G-124B & & \\
\hline & & KBL-G-125A & \multirow{2}{*}{26.90} & \multirow{2}{*}{204.40} \\
\hline & & KBL-G-125B & & \\
\hline & & KBL-G-127A & \multirow{2}{*}{20.98} & \multirow{2}{*}{225.38} \\
\hline & & KBL-G-127B & & \\
\hline \multirow{15}{*}{2} & & KBL-G-133A & \multirow{2}{*}{28.40} & \multirow{2}{*}{253.78} \\
\hline & & KBL-G-134A & & \\
\hline & \multirow{6}{*}{ 8/23/2012 } & KBL-G-137A & \multirow{2}{*}{19.14} & 272 בר \\
\hline & & KBL-G-137B & & \\
\hline & & KBL-G-141A & 2110 & 2040 \\
\hline & & KBL-G-141B & 31.10 & 304.02 \\
\hline & & KBL-G-141C & 2607 & 32094 \\
\hline & & KBL-G-143A & 26.92 & 330.94 \\
\hline & & KBL-G-143B & 1856 & 34950 \\
\hline & & KBL-G-148A & 18.56 & 349.50 \\
\hline & & KBL-G-148B & 2616 & 37566 \\
\hline & 8/23/2012 & KBL-G-148C & 26.16 & $3 / 5.66$ \\
\hline & & KBL-G-148D & 22 28 & 40388 \\
\hline & & LBL-G-7A & & \\
\hline & & LBL-G-8A & 10.92 & 414.80 \\
\hline
\end{tabular}


ORP-56288 Rev. 0

The Catholic University of America

Vitreous State Laboratory
Melter Testing of New High Bismuth HLW Formulations Final Report, VSL-13R2770-1, Rev. 0

Table 4.3 List of Glass Discharged and Masses (continued).

\begin{tabular}{|c|c|c|c|c|}
\hline Test & Date & Name & Mass (kg) & Cumulative Mass (kg) \\
\hline \multirow{31}{*}{3} & \multirow{4}{*}{ 8/27/2012 } & LBL-G-25A & \multirow{2}{*}{33.58} & \multirow{2}{*}{448.38} \\
\hline & & LBL-G-27A & & \\
\hline & & LBL-G-27B & \multirow{2}{*}{27.60} & \multirow{2}{*}{475.98} \\
\hline & & LBL-G-28A & & \\
\hline & \multirow{17}{*}{ 8/28/2012 } & LBL-G-28B & \multirow{2}{*}{15.98} & \multirow{2}{*}{491.96} \\
\hline & & LBL-G-28C & & \\
\hline & & LBL-G-31A & \multirow{3}{*}{23.58} & \multirow{3}{*}{515.54} \\
\hline & & LBL-G-31B & & \\
\hline & & LBL-G-31C & & \\
\hline & & LBL-G-33A & \multirow{2}{*}{20.22} & \multirow{2}{*}{535.76} \\
\hline & & LBL-G-33B & & \\
\hline & & LBL-G-33C & \multirow{2}{*}{18.60} & \multirow{2}{*}{554.36} \\
\hline & & LBL-G-36A & & \\
\hline & & LBL-G-36B & \multirow{2}{*}{18.84} & \multirow{2}{*}{573.20} \\
\hline & & LBL-G-36C & & \\
\hline & & LBL-G-36D & \multirow{2}{*}{27.96} & \multirow{2}{*}{601.16} \\
\hline & & LBL-G-36E & & \\
\hline & & LBL-G-39A & \multirow{2}{*}{24.78} & \multirow{2}{*}{625.94} \\
\hline & & LBL-G-39B & & \\
\hline & & LBL-G-39C & \multirow{2}{*}{23.72} & \multirow{2}{*}{649.66} \\
\hline & & LBL-G-39D & & \\
\hline & \multirow{13}{*}{ 8/29/2012 } & LBL-G-43A & \multirow{2}{*}{26.14} & \multirow{2}{*}{675.80} \\
\hline & & LBL-G-43B & & \\
\hline & & LBL-G-43C & \multirow{2}{*}{24.44} & \multirow{2}{*}{700.24} \\
\hline & & LBL-G-43D & & \\
\hline & & LBL-G-45A & \multirow{2}{*}{21.46} & 72170 \\
\hline & & LBL-G-45B & & $121 . / 0$ \\
\hline & & LBL-G-45C & 2268 & 74438 \\
\hline & & LBL-G-45D & 22.00 & 144.30 \\
\hline & & LBL-G-50A & ג? ח? & 78167 \\
\hline & & LBL-G-50B & 20.24 & 104.02 \\
\hline & & LBL-G-50C & & \\
\hline 4 & & LBL-G-50D & 26.22 & 790.84 \\
\hline & & LBL-G-51A & & \\
\hline
\end{tabular}


ORP-56288 Rev. 0

The Catholic University of America

Vitreous State Laboratory
Melter Testing of New High Bismuth HLW Formulations Final Report, VSL-13R2770-1, Rev. 0

Table 4.3. List of Glass Discharged and Masses (continued).

\begin{tabular}{|c|c|c|c|c|}
\hline Test & Date & Name & Mass (kg) & Cumulative Mass (kg) \\
\hline \multirow{29}{*}{4} & \multirow{4}{*}{ 8/29/2012 } & LBL-G-51B & \multirow{2}{*}{29.36} & \multirow{2}{*}{820.20} \\
\hline & & LBL-G-51C & & \\
\hline & & LBL-G-53A & \multirow{2}{*}{17.34} & \multirow{2}{*}{837.54} \\
\hline & & LBL-G-53B & & \\
\hline & \multirow{16}{*}{ 8/30/2012 } & LBL-G-53C & \multirow{2}{*}{19.50} & \multirow{2}{*}{857.04} \\
\hline & & LBL-G-53D & & \\
\hline & & LBL-G-53E & \multirow{2}{*}{21.08} & \multirow{2}{*}{878.12} \\
\hline & & LBL-G-53F & & \\
\hline & & LBL-G-57A & \multirow{2}{*}{22.06} & \multirow{2}{*}{900.18} \\
\hline & & LBL-G-57B & & \\
\hline & & LBL-G-57C & \multirow{2}{*}{16.68} & \multirow{2}{*}{916.86} \\
\hline & & LBL-G-57D & & \\
\hline & & LBL-G-57E & \multirow{2}{*}{24.04} & \multirow{2}{*}{940.90} \\
\hline & & LBL-G-61A & & \\
\hline & & LBL-G-61B & \multirow{2}{*}{24.62} & \multirow{2}{*}{965.52} \\
\hline & & LBL-G-63A & & \\
\hline & & LBL-G-63B & \multirow{2}{*}{26.94} & \multirow{2}{*}{992.46} \\
\hline & & LBL-G-63C & & \\
\hline & & LBL-G-65A & \multirow{2}{*}{20.20} & \multirow{2}{*}{1012.66} \\
\hline & & LBL-G-65B & & \\
\hline & \multirow{9}{*}{ 8/31/2012 } & LBL-G-65C & \multirow{2}{*}{19.24} & \multirow{2}{*}{1031.90} \\
\hline & & LBL-G-65D & & \\
\hline & & LBL-G-69A & \multirow{2}{*}{22.58} & \multirow{2}{*}{1054.48} \\
\hline & & LBL-G-69B & & \\
\hline & & LBL-G-69C & 20.28 & 1074.76 \\
\hline & & LBL-G-69D & \multirow{2}{*}{23.82} & \multirow{2}{*}{1098.58} \\
\hline & & LBL-G-71A & & \\
\hline & & LBL-G-71B & \multirow{2}{*}{18.78} & \multirow{2}{*}{1117.36} \\
\hline & & LBL-G-71C & & \\
\hline
\end{tabular}


Table 4.4. XRF Analyzed Composition for Glass Discharged During DM100 Melter Tests (wt \%).

\begin{tabular}{|c|c|c|c|c|c|c|c|c|c|c|}
\hline \multicolumn{2}{|l|}{ Test } & \multicolumn{9}{|c|}{1} \\
\hline \multicolumn{2}{|c|}{ Formulation } & \multicolumn{9}{|c|}{ HLW-Bi-F3 } \\
\hline \multicolumn{2}{|c|}{ Mass (kg) } & 9.92 & 30.22 & 49.80 & 69.14 & 90.38 & 112.30 & 136.70 & 156.42 & 177.50 \\
\hline Constituent & Target & \begin{tabular}{|c|} 
KBL-G- \\
$108 A$
\end{tabular} & $\begin{array}{c}\text { KBL-G- } \\
109 B\end{array}$ & $\begin{array}{c}\text { KBL-G- } \\
114 \mathrm{~A}\end{array}$ & $\begin{array}{c}\text { KBL-G- } \\
114 \mathrm{C}\end{array}$ & \begin{tabular}{|c|} 
KBL-G- \\
$115 B$
\end{tabular} & $\begin{array}{c}\text { KBL-G- } \\
115 \mathrm{D}\end{array}$ & $\begin{array}{c}\text { KBL-G- } \\
119 B\end{array}$ & $\begin{array}{c}\text { KBL-G- } \\
123 B\end{array}$ & $\begin{array}{c}\text { KBL-G- } \\
124 \mathrm{~B}\end{array}$ \\
\hline $\mathrm{Al}_{2} \mathrm{O}_{3}$ & 11.65 & 11.49 & 11.72 & 11.76 & 11.76 & 11.84 & 11.92 & 12.06 & 12.09 & 12.07 \\
\hline $\mathrm{B}_{2} \mathrm{O}_{3}{ }^{*}$ & 10.29 & $11.06^{\$}$ & 10.87 & 10.70 & 10.56 & 10.41 & 10.28 & 10.15 & 10.06 & 9.97 \\
\hline $\mathrm{BaO}$ & 0.01 & 0.01 & 0.05 & 0.04 & 0.01 & $<0.01$ & 0.03 & 0.04 & 0.03 & 0.02 \\
\hline $\mathrm{Bi}_{2} \mathrm{O}_{3}$ & 6.71 & 6.69 & 6.59 & 6.70 & 6.82 & 6.85 & 6.68 & 6.38 & 6.45 & 6.69 \\
\hline $\mathrm{CaO}$ & 0.84 & 0.85 & 0.86 & 0.86 & 0.84 & 0.88 & 0.86 & 0.80 & 0.82 & 0.81 \\
\hline $\mathrm{CdO}$ & $\S$ & 0.02 & 0.02 & 0.02 & 0.02 & 0.02 & 0.02 & 0.01 & 0.01 & 0.01 \\
\hline $\mathrm{Cl}$ & $\S$ & 0.03 & 0.03 & 0.02 & 0.02 & 0.02 & 0.01 & 0.02 & 0.01 & 0.01 \\
\hline $\mathrm{Cr}_{2} \mathrm{O}_{3}$ & 0.52 & 0.43 & 0.44 & 0.43 & 0.45 & 0.46 & 0.42 & 0.42 & 0.44 & 0.43 \\
\hline $\mathrm{F}$ & 0.82 & $0.34^{\#}$ & 0.35 & $0.37^{\#}$ & 0.38 & $0.39^{\#}$ & 0.39 & 0.40 & $0.40^{\#}$ & 0.41 \\
\hline $\mathrm{Fe}_{2} \mathrm{O}_{3}$ & 6.96 & 7.98 & 7.78 & 7.67 & 7.70 & 7.55 & 7.48 & 6.97 & 7.10 & 7.20 \\
\hline $\mathrm{K}_{2} \mathrm{O}$ & 0.46 & 0.39 & 0.37 & 0.34 & 0.39 & 0.31 & 0.41 & 0.43 & 0.39 & 0.51 \\
\hline $\mathrm{Li}_{2} \mathrm{O}^{*}$ & 0.16 & $0.39^{\$}$ & 0.37 & 0.35 & 0.33 & 0.32 & 0.30 & 0.29 & 0.28 & 0.27 \\
\hline $\mathrm{MgO}$ & 0.43 & 0.37 & 0.39 & 0.40 & 0.39 & 0.46 & 0.42 & 0.43 & 0.44 & 0.43 \\
\hline $\mathrm{MnO}$ & $\S$ & 0.27 & 0.24 & 0.20 & 0.19 & 0.18 & 0.16 & 0.13 & 0.11 & 0.11 \\
\hline $\mathrm{Na}_{2} \mathrm{O}$ & 18.73 & 15.66 & 15.92 & 16.15 & 15.92 & 16.58 & 16.75 & 17.51 & 17.33 & 17.49 \\
\hline $\mathrm{NiO}$ & 1.93 & 1.72 & 1.71 & 1.77 & 1.79 & 1.81 & 1.76 & 1.70 & 1.75 & 1.86 \\
\hline $\mathrm{P}_{2} \mathrm{O}_{5}$ & 4.99 & 5.12 & 5.21 & 5.23 & 5.31 & 5.15 & 5.27 & 5.42 & 5.39 & 5.33 \\
\hline $\mathrm{PbO}$ & 0.25 & 0.39 & 0.38 & 0.35 & 0.37 & 0.35 & 0.30 & 0.27 & 0.26 & 0.27 \\
\hline $\mathrm{SiO}_{2}$ & 34.24 & 35.53 & 35.50 & 35.47 & 35.52 & 35.25 & 35.40 & 35.43 & 35.55 & 35.04 \\
\hline $\mathrm{SO}_{3}$ & 0.48 & 0.43 & 0.41 & 0.41 & 0.42 & 0.42 & 0.41 & 0.44 & 0.42 & 0.40 \\
\hline $\mathrm{SrO}$ & $\S$ & 0.03 & 0.03 & 0.02 & 0.02 & 0.02 & 0.02 & 0.02 & 0.02 & 0.01 \\
\hline $\mathrm{TiO}_{2}$ & 0.16 & 0.17 & 0.17 & 0.17 & 0.19 & 0.17 & 0.18 & 0.18 & 0.16 & 0.19 \\
\hline $\mathrm{ZnO}$ & 0.16 & 0.18 & 0.18 & 0.17 & 0.17 & 0.18 & 0.16 & 0.16 & 0.16 & 0.16 \\
\hline $\mathrm{ZrO}_{2}$ & 0.21 & 0.45 & 0.42 & 0.39 & 0.41 & 0.39 & 0.37 & 0.33 & 0.32 & 0.33 \\
\hline Sum & 100.00 & 100.00 & 100.00 & 100.00 & 100.00 & 100.00 & 100.00 & 100.00 & 100.00 & 100.00 \\
\hline
\end{tabular}


ORP-56288 Rev. 0

The Catholic University of America

Vitreous State Laboratory

Table 4.4. XRF Analyzed Composition for Glass Discharged During DM100 Melter Tests (wt\%) (continued).

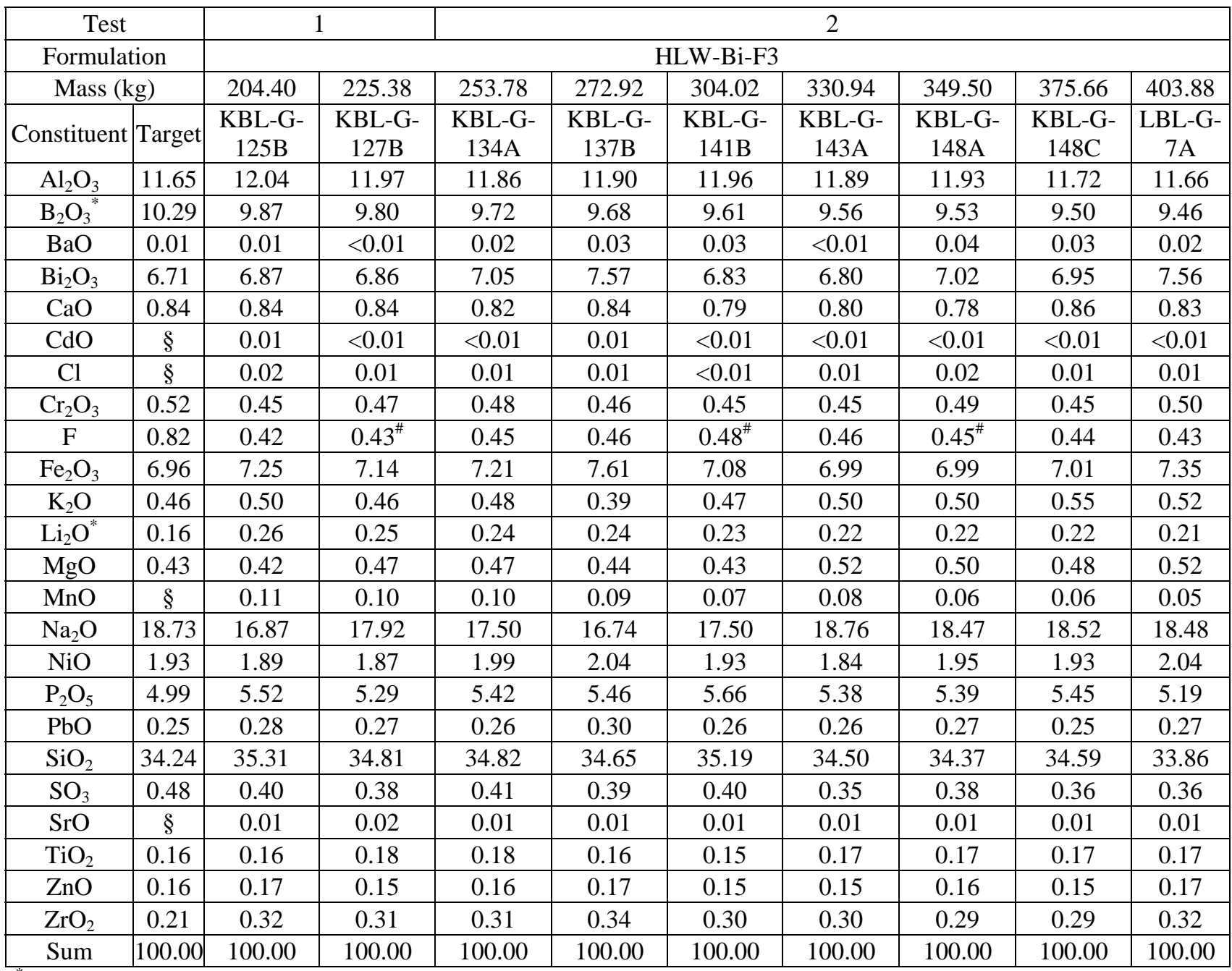

- Values calculated from $\mathrm{B}_{2} \mathrm{O}_{3}$ and $\mathrm{Li}_{2} \mathrm{O}$ analysis by DCP-AES on the first discharged glass and feed samples using a simple well stirred tank model

$\S$ - Not a target constituent

\# - Analyzed by XRF and values for other samples calculated by interpolation 
Table 4.4. XRF Analyzed Composition for Glass Discharged During DM100 Melter Tests (wt\%) (continued.

\begin{tabular}{|c|c|c|c|c|c|c|c|c|c|}
\hline Test & \multicolumn{3}{|c|}{2} & \multicolumn{6}{|c|}{3} \\
\hline Formulation & \multicolumn{3}{|c|}{ HLW-Bi-F3 } & \multicolumn{6}{|c|}{ HLW-Bi-F9 } \\
\hline Mass (kg) & \multirow{2}{*}{ Target } & \multicolumn{2}{|c|}{414.80} & \multirow{2}{*}{ Target } & \multirow{2}{*}{\begin{tabular}{|c|}
448.38 \\
LBL-G-27A
\end{tabular}} & \multirow{2}{*}{$\begin{array}{c}475.98 \\
\text { LBL-G-28A }\end{array}$} & \multirow{2}{*}{\begin{tabular}{|c|c}
491.96 \\
LBL-G-28C
\end{tabular}} & \multirow{2}{*}{$\begin{array}{c}515.54 \\
\text { LBL-G-31C }\end{array}$} & \multirow{2}{*}{\begin{tabular}{|c|}
535.76 \\
LBL-G-33B \\
\end{tabular}} \\
\hline Constituent & & LBL-G-8A & \% Dev. & & & & & & \\
\hline $\mathrm{Al}_{2} \mathrm{O}_{3}$ & 11.65 & 11.63 & -0.17 & 16.65 & 13.00 & 13.35 & 13.36 & 14.48 & 14.49 \\
\hline $\mathrm{B}_{2} \mathrm{O}_{3}{ }^{*}$ & 10.29 & $9.60^{\$}$ & -6.75 & 16.29 & $11.07^{\$}$ & 11.74 & 12.08 & 12.54 & 12.89 \\
\hline $\mathrm{BaO}$ & 0.01 & $<0.01$ & NC & 0.01 & $<0.01$ & 0.03 & 0.11 & $<0.01$ & $<0.01$ \\
\hline $\mathrm{Bi}_{2} \mathrm{O}_{3}$ & 6.71 & 7.41 & 10.52 & 6.71 & 6.27 & 6.45 & 6.66 & 6.42 & 6.61 \\
\hline $\mathrm{CaO}$ & 0.84 & 0.79 & NC & 0.84 & 0.71 & 0.74 & 0.77 & 0.79 & 0.74 \\
\hline $\mathrm{CdO}$ & $\S$ & 0.01 & NC & $\S$ & $<0.01$ & 0.01 & $<0.01$ & $<0.01$ & $<0.01$ \\
\hline $\mathrm{Cl}$ & $\S$ & 0.02 & NC & $\S$ & $<0.01$ & $<0.01$ & $<0.01$ & 0.01 & 0.01 \\
\hline $\mathrm{Cr}_{2} \mathrm{O}_{3}$ & 0.52 & 0.46 & NC & 0.52 & 0.42 & 0.38 & 0.41 & 0.38 & 0.41 \\
\hline $\mathrm{F}$ & 0.82 & $0.43^{\#}$ & NC & 0.82 & $0.37^{\#}$ & 0.37 & $0.37^{\#}$ & 0.38 & 0.38 \\
\hline $\mathrm{Fe}_{2} \mathrm{O}_{3}$ & 6.96 & 7.26 & 4.31 & 6.96 & 6.35 & 6.34 & 6.50 & 6.36 & 6.42 \\
\hline $\mathrm{K}_{2} \mathrm{O}$ & 0.46 & 0.34 & NC & 0.46 & 0.43 & 0.35 & 0.48 & 0.47 & 0.46 \\
\hline $\mathrm{Li}_{2} \mathrm{O}^{*}$ & 0.16 & $0.26^{\$}$ & NC & 5.16 & $1.32^{\$}$ & 1.84 & 2.10 & 2.46 & 2.72 \\
\hline $\mathrm{MgO}$ & 0.43 & 0.51 & NC & 0.43 & 0.50 & 0.48 & 0.48 & 0.46 & 0.49 \\
\hline $\mathrm{MnO}$ & $\S$ & 0.08 & NC & $\S$ & 0.06 & 0.06 & 0.05 & 0.05 & 0.04 \\
\hline $\mathrm{Na}_{2} \mathrm{O}$ & 18.73 & 18.70 & -0.19 & 7.74 & 17.67 & 16.30 & 15.51 & 13.93 & 13.68 \\
\hline $\mathrm{NiO}$ & 1.93 & 2.06 & 6.69 & 1.93 & 1.63 & 1.62 & 1.73 & 1.59 & 1.57 \\
\hline $\mathrm{P}_{2} \mathrm{O}_{5}$ & 4.99 & 5.30 & 6.20 & 4.99 & 5.35 & 5.39 & 5.39 & 5.64 & 5.61 \\
\hline $\mathrm{PbO}$ & 0.25 & 0.26 & NC & 0.25 & 0.23 & 0.23 & 0.24 & 0.23 & 0.24 \\
\hline $\mathrm{SiO}_{2}$ & 34.24 & 33.87 & -1.10 & 29.25 & 33.69 & 33.37 & 32.80 & 32.88 & 32.32 \\
\hline $\mathrm{SO}_{3}$ & 0.48 & 0.38 & NC & 0.48 & 0.37 & 0.38 & 0.37 & 0.35 & 0.35 \\
\hline $\mathrm{SrO}$ & $\S$ & 0.01 & NC & $\S$ & 0.01 & 0.01 & 0.01 & 0.01 & $<0.01$ \\
\hline $\mathrm{TiO}_{2}$ & 0.16 & 0.15 & $\mathrm{NC}$ & 0.16 & 0.17 & 0.18 & 0.20 & 0.21 & 0.22 \\
\hline $\mathrm{ZnO}$ & 0.16 & 0.18 & $\mathrm{NC}$ & 0.16 & 0.14 & 0.14 & 0.15 & 0.15 & 0.14 \\
\hline $\mathrm{ZrO}_{2}$ & 0.21 & 0.31 & NC & 0.21 & 0.23 & 0.23 & 0.24 & 0.21 & 0.21 \\
\hline Sum & 100.00 & 100.00 & NC & 100.00 & 100.00 & 100.00 & 100.00 & 100.00 & 100.00 \\
\hline
\end{tabular}

* - Values calculated from $\mathrm{B}_{2} \mathrm{O}_{3}$ and $\mathrm{Li}_{2} \mathrm{O}$ analysis by DCP-AES on the first discharged glass and feed samples using a simple well stirred tank model

$\S$ - Not a target constituent

$\$$ - DCP-AES result

\# - Analyzed by XRF and values for other samples calculated by interpolation

NC - Not calculated 
ORP-56288 Rev. 0

The Catholic University of America

Vitreous State Laboratory

Table 4.4. XRF Analyzed Composition for Glass Discharged During DM100 Melter Tests (wt\%) (continued).

\begin{tabular}{|c|c|c|c|c|c|c|c|c|c|c|}
\hline \multirow{3}{*}{\multicolumn{2}{|c|}{\begin{tabular}{|c|} 
Test \\
Formulation \\
Mass (kg)
\end{tabular}}} & \multicolumn{9}{|c|}{3} \\
\hline & & \multirow{4}{*}{$\begin{array}{c}554.36 \\
\begin{array}{c}\text { LBL-G- } \\
36 A\end{array} \\
14.40\end{array}$} & \multicolumn{7}{|c|}{ HLW-Bi-F9 } & \multirow{3}{*}{$\begin{array}{c}744.38 \\
\text { LBL-G- } \\
45 \mathrm{D}\end{array}$} \\
\hline & & & 573.20 & 601.16 & 625.94 & 649.66 & 675.80 & 700.24 & 721.70 & \\
\hline Constituent & Target & & $\begin{array}{c}\text { LBL-G- } \\
\text { 36C }\end{array}$ & $\begin{array}{c}\text { LBL-G- } \\
36 \mathrm{E}\end{array}$ & $\begin{array}{c}\text { LBL-G- } \\
39 B\end{array}$ & $\begin{array}{c}\text { LBL-G- } \\
\text { 39D }\end{array}$ & $\begin{array}{c}\text { LBL-G- } \\
43 B\end{array}$ & $\begin{array}{c}\text { LBL-G- } \\
43 \mathrm{D}\end{array}$ & $\begin{array}{c}\text { LBL-G- } \\
45 B\end{array}$ & \\
\hline $\mathrm{Al}_{2} \mathrm{O}_{3}$ & 16.65 & & 14.59 & 15.08 & 15.31 & 15.27 & 15.52 & 15.42 & 15.60 & 15.51 \\
\hline $\mathrm{B}_{2} \mathrm{O}_{3}{ }^{*}$ & 16.29 & 13.17 & 13.43 & 13.77 & 14.03 & 14.25 & 14.46 & 14.63 & 14.76 & 14.88 \\
\hline $\mathrm{BaO}$ & 0.01 & $<0.01$ & $<0.01$ & 0.04 & 0.04 & 0.04 & $<0.01$ & 0.01 & 0.01 & 0.02 \\
\hline $\mathrm{Bi}_{2} \mathrm{O}_{3}$ & 6.71 & 6.95 & 6.52 & 6.35 & 6.71 & 6.60 & 6.64 & 6.92 & 6.84 & 7.15 \\
\hline $\mathrm{CaO}$ & 0.84 & 0.79 & 0.79 & 0.76 & 0.75 & 0.77 & 0.77 & 0.78 & 0.79 & 0.82 \\
\hline $\mathrm{CdO}$ & $\S$ & $<0.01$ & $<0.01$ & $<0.01$ & $<0.01$ & $<0.01$ & $<0.01$ & $<0.01$ & $<0.01$ & $<0.01$ \\
\hline $\mathrm{Cl}$ & $\S$ & 0.01 & 0.01 & 0.01 & $<0.01$ & $<0.01$ & $<0.01$ & 0.01 & 0.01 & $<0.01$ \\
\hline $\mathrm{Cr}_{2} \mathrm{O}_{3}$ & 0.52 & 0.42 & 0.40 & 0.39 & 0.44 & 0.41 & 0.38 & 0.47 & 0.42 & 0.46 \\
\hline $\mathrm{F}$ & 0.82 & $0.39^{\#}$ & 0.38 & 0.35 & $0.33^{\#}$ & 0.34 & 0.34 & $0.34^{\#}$ & 0.33 & 0.33 \\
\hline $\mathrm{Fe}_{2} \mathrm{O}_{3}$ & 6.96 & 6.77 & 6.36 & 6.16 & 6.41 & 6.41 & 6.25 & 6.59 & 6.54 & 6.61 \\
\hline $\mathrm{K}_{2} \mathrm{O}$ & 0.46 & 0.49 & 0.46 & 0.46 & 0.47 & 0.47 & 0.46 & 0.47 & 0.43 & 0.49 \\
\hline $\mathrm{Li}_{2} \mathrm{O}^{*}$ & 5.16 & 2.94 & 3.15 & 3.41 & 3.61 & 3.78 & 3.94 & 4.07 & 4.17 & 4.27 \\
\hline $\mathrm{MgO}$ & 0.43 & 0.48 & 0.54 & 0.54 & 0.52 & 0.54 & 0.53 & 0.51 & 0.54 & 0.53 \\
\hline $\mathrm{MnO}$ & $\S$ & 0.05 & 0.05 & 0.04 & 0.04 & 0.02 & 0.03 & 0.03 & 0.03 & 0.03 \\
\hline $\mathrm{Na}_{2} \mathrm{O}$ & 7.74 & 13.08 & 13.21 & 12.74 & 11.74 & 11.26 & 11.07 & 10.50 & 10.48 & 9.99 \\
\hline $\mathrm{NiO}$ & 1.93 & 1.70 & 1.57 & 1.49 & 1.55 & 1.59 & 1.47 & 1.57 & 1.62 & 1.67 \\
\hline $\mathrm{P}_{2} \mathrm{O}_{5}$ & 4.99 & 5.51 & 5.55 & 5.68 & 5.54 & 5.62 & 5.69 & 5.63 & 5.58 & 5.60 \\
\hline $\mathrm{PbO}$ & 0.25 & 0.25 & 0.23 & 0.23 & 0.23 & 0.24 & 0.24 & 0.25 & 0.24 & 0.24 \\
\hline $\mathrm{SiO}_{2}$ & 29.25 & 31.63 & 31.84 & 31.60 & 31.35 & 31.50 & 31.31 & 30.87 & 30.71 & 30.46 \\
\hline $\mathrm{SO}_{3}$ & 0.48 & 0.37 & 0.36 & 0.34 & 0.34 & 0.34 & 0.32 & 0.33 & 0.31 & 0.32 \\
\hline $\mathrm{SrO}$ & $\S$ & $<0.01$ & $<0.01$ & $<0.01$ & $<0.01$ & $<0.01$ & $<0.01$ & $<0.01$ & $<0.01$ & $<0.01$ \\
\hline $\mathrm{TiO}_{2}$ & 0.16 & 0.22 & 0.23 & 0.22 & 0.25 & 0.23 & 0.26 & 0.26 & 0.26 & 0.29 \\
\hline $\mathrm{ZnO}$ & 0.16 & 0.15 & 0.15 & 0.14 & 0.13 & 0.14 & 0.15 & 0.14 & 0.15 & 0.15 \\
\hline $\mathrm{ZrO}_{2}$ & 0.21 & 0.22 & 0.19 & 0.19 & 0.19 & 0.20 & 0.19 & 0.19 & 0.19 & 0.19 \\
\hline Sum & 100.00 & 100.00 & 100.00 & 100.00 & 100.00 & 100.00 & 100.00 & 100.00 & 100.00 & 100.00 \\
\hline
\end{tabular}

- Values calculated from $\mathrm{B}_{2} \mathrm{O}_{3}$ and $\mathrm{Li}_{2} \mathrm{O}$ analysis by DCP-AES on the first discharged glass and feed samples using a simple well stirred tank model

$\S$ - Not a target constituent

\# - Analyzed by XRF and values for other samples calculated by interpolation 
ORP-56288 Rev. 0

The Catholic University of America

Vitreous State Laboratory

Table 4.4. XRF Analyzed Composition for Glass Discharged During DM100 Melter Tests (wt\%) (continued).

\begin{tabular}{|c|c|c|c|c|c|c|c|c|c|c|}
\hline Test & \multicolumn{10}{|c|}{4} \\
\hline Formulation & \multirow[b]{3}{*}{ Target } & \multicolumn{9}{|c|}{ HLW-Bi-F9 } \\
\hline \begin{tabular}{|l|} 
Mass (kg) \\
\end{tabular} & & 764.62 & 790.84 & 820.20 & 837.54 & 857.04 & 878.12 & 900.18 & 916.86 & 940.90 \\
\hline Constituent & & $\begin{array}{c}\text { LBL-G- } \\
50 \mathrm{~B}\end{array}$ & $\begin{array}{c}\text { LBL-G- } \\
51 \mathrm{~A}\end{array}$ & $\begin{array}{c}\text { LBL-G- } \\
51 \mathrm{C}\end{array}$ & $\begin{array}{c}\text { LBL-G- } \\
53 B\end{array}$ & $\begin{array}{c}\text { LBL-G- } \\
53 \mathrm{D}\end{array}$ & $\begin{array}{c}\text { LBL-G- } \\
53 F\end{array}$ & $\begin{array}{c}\text { LBL-G- } \\
57 \mathrm{~B}\end{array}$ & $\begin{array}{c}\text { LBL-G- } \\
\text { 57D }\end{array}$ & $\begin{array}{c}\text { LBL-G- } \\
61 \mathrm{~A}\end{array}$ \\
\hline $\mathrm{Al}_{2} \mathrm{O}_{3}$ & 16.65 & 15.63 & 15.55 & 15.80 & 15.71 & 15.64 & 15.74 & 15.77 & 15.86 & 15.78 \\
\hline $\mathrm{B}_{2} \mathrm{O}_{3}{ }^{*}$ & 16.29 & 14.98 & 15.09 & 15.19 & 15.25 & 15.30 & 15.36 & 15.41 & 15.44 & 15.48 \\
\hline $\mathrm{BaO}$ & 0.01 & 0.03 & 0.02 & 0.04 & $<0.01$ & $<0.01$ & 0.04 & 0.04 & $<0.01$ & 0.04 \\
\hline $\mathrm{Bi}_{2} \mathrm{O}_{3}$ & 6.71 & 6.88 & 7.05 & 6.99 & 6.87 & 7.21 & 7.05 & 6.89 & 7.23 & 7.24 \\
\hline $\mathrm{CaO}$ & 0.84 & 0.77 & 0.78 & 0.76 & 0.77 & 0.80 & 0.78 & 0.78 & 0.85 & 0.77 \\
\hline $\mathrm{CdO}$ & $\S$ & $<0.01$ & $<0.01$ & $<0.01$ & $<0.01$ & $<0.01$ & $<0.01$ & $<0.01$ & $<0.01$ & $<0.01$ \\
\hline $\mathrm{Cl}$ & $\S$ & $<0.01$ & $<0.01$ & $<0.01$ & $<0.01$ & 0.01 & 0.01 & $<0.01$ & 0.01 & $<0.01$ \\
\hline $\mathrm{Cr}_{2} \mathrm{O}_{3}$ & 0.52 & 0.41 & 0.44 & 0.45 & 0.43 & 0.44 & 0.43 & 0.47 & 0.42 & 0.51 \\
\hline $\mathrm{F}$ & 0.82 & $0.32^{\#}$ & 0.31 & 0.31 & 0.30 & $0.29^{\#}$ & 0.30 & 0.30 & 0.30 & $0.30^{\#}$ \\
\hline $\mathrm{Fe}_{2} \mathrm{O}_{3}$ & 6.96 & 6.62 & 6.76 & 6.67 & 6.51 & 6.73 & 6.65 & 6.70 & 6.72 & 6.68 \\
\hline $\mathrm{K}_{2} \mathrm{O}$ & 0.46 & 0.46 & 0.48 & 0.45 & 0.47 & 0.46 & 0.50 & 0.50 & 0.46 & 0.46 \\
\hline $\mathrm{Li}_{2} \mathrm{O}^{*}$ & 5.16 & 4.34 & 4.43 & 4.51 & 4.55 & 4.59 & 4.63 & 4.67 & 4.70 & 4.73 \\
\hline $\mathrm{MgO}$ & 0.43 & 0.57 & 0.52 & 0.52 & 0.58 & 0.52 & 0.53 & 0.53 & 0.55 & 0.54 \\
\hline $\mathrm{MnO}$ & $\S$ & 0.02 & 0.02 & 0.03 & 0.02 & 0.03 & 0.03 & 0.02 & 0.03 & 0.03 \\
\hline $\mathrm{Na}_{2} \mathrm{O}$ & 7.74 & 9.93 & 9.67 & 9.63 & 10.15 & 9.27 & 9.20 & 9.11 & 8.85 & 8.98 \\
\hline $\mathrm{NiO}$ & 1.93 & 1.64 & 1.62 & 1.67 & 1.60 & 1.68 & 1.64 & 1.65 & 1.62 & 1.66 \\
\hline $\mathrm{P}_{2} \mathrm{O}_{5}$ & 4.99 & 5.53 & 5.58 & 5.49 & 5.60 & 5.55 & 5.61 & 5.64 & 5.56 & 5.70 \\
\hline $\mathrm{PbO}$ & 0.25 & 0.26 & 0.26 & 0.24 & 0.24 & 0.24 & 0.25 & 0.25 & 0.26 & 0.25 \\
\hline $\mathrm{SiO}_{2}$ & 29.25 & 30.68 & 30.51 & 30.34 & 30.10 & 30.34 & 30.33 & 30.38 & 30.26 & 29.96 \\
\hline $\mathrm{SO}_{3}$ & 0.48 & 0.32 & 0.31 & 0.31 & 0.29 & 0.28 & 0.30 & 0.30 & 0.27 & 0.27 \\
\hline $\mathrm{SrO}$ & $\S$ & $<0.01$ & $<0.01$ & $<0.01$ & $<0.01$ & $<0.01$ & $<0.01$ & $<0.01$ & $<0.01$ & $<0.01$ \\
\hline $\mathrm{TiO}_{2}$ & 0.16 & 0.27 & 0.26 & 0.27 & 0.25 & 0.28 & 0.28 & 0.25 & 0.27 & 0.27 \\
\hline $\mathrm{ZnO}$ & 0.16 & 0.14 & 0.15 & 0.16 & 0.14 & 0.15 & 0.14 & 0.15 & 0.15 & 0.16 \\
\hline $\mathrm{ZrO}_{2}$ & 0.21 & 0.18 & 0.20 & 0.18 & 0.18 & 0.18 & 0.18 & 0.18 & 0.19 & 0.18 \\
\hline Sum & 100.00 & 100.00 & 100.00 & 100.00 & 100.00 & 100.00 & 100.00 & 100.00 & 100.00 & 100.00 \\
\hline
\end{tabular}


Table 4.4. XRF Analyzed Composition for Glass Discharged During DM100 Melter Tests (wt\%) (continued).

\begin{tabular}{|c|c|c|c|c|c|c|c|c|c|c|}
\hline Test & \multicolumn{10}{|c|}{4} \\
\hline Formulation & \multicolumn{10}{|c|}{ HLW-Bi-F9 } \\
\hline Mass (kg) & \multirow{2}{*}{ Target } & 965.52 & 992.46 & 1012.66 & 1031.90 & 1054.48 & \begin{tabular}{|l|}
1074.76 \\
\end{tabular} & \begin{tabular}{|l|}
1098.58 \\
\end{tabular} & \multicolumn{2}{|c|}{1117.36} \\
\hline Constituent & & $\begin{array}{c}\text { LBL-G- } \\
63 \mathrm{~A}\end{array}$ & $\begin{array}{c}\text { LBL-G- } \\
63 C\end{array}$ & $\begin{array}{c}\text { LBL-G- } \\
65 B\end{array}$ & \begin{tabular}{|c|} 
LBL-G- \\
$65 \mathrm{D}$
\end{tabular} & $\begin{array}{c}\text { LBL-G- } \\
69 B\end{array}$ & \begin{tabular}{|c|} 
LBL-G- \\
$69 C$
\end{tabular} & $\begin{array}{c}\text { LBL-G- } \\
71 \mathrm{~A}\end{array}$ & $\begin{array}{c}\text { LBL-G- } \\
71 \mathrm{C}\end{array}$ & \% Dev. \\
\hline $\mathrm{Al}_{2} \mathrm{O}_{3}$ & 16.65 & 15.83 & 15.70 & 15.93 & 15.84 & 16.06 & 15.96 & 16.06 & 15.95 & -4.19 \\
\hline $\mathrm{B}_{2} \mathrm{O}_{3}{ }^{*}$ & 16.29 & 15.52 & 15.56 & 15.58 & 15.61 & 15.63 & 15.64 & 15.66 & $15.66^{\$}$ & -3.88 \\
\hline $\mathrm{BaO}$ & 0.01 & 0.03 & 0.04 & $<0.01$ & 0.03 & 0.03 & 0.03 & 0.02 & 0.03 & $\mathrm{NC}$ \\
\hline $\mathrm{Bi}_{2} \mathrm{O}_{3}$ & 6.71 & 7.25 & 7.24 & 7.03 & 7.01 & 6.92 & 7.04 & 6.88 & 7.21 & 7.50 \\
\hline $\mathrm{CaO}$ & 0.84 & 0.80 & 0.78 & 0.80 & 0.80 & 0.79 & 0.78 & 0.79 & 0.80 & NC \\
\hline $\mathrm{CdO}$ & $\S$ & $<0.01$ & $<0.01$ & $<0.01$ & $<0.01$ & $<0.01$ & $<0.01$ & $<0.01$ & $<0.01$ & NC \\
\hline $\mathrm{Cl}$ & $\S$ & 0.01 & $<0.01$ & 0.01 & $<0.01$ & 0.01 & 0.01 & 0.01 & $<0.01$ & NC \\
\hline $\mathrm{Cr}_{2} \mathrm{O}_{3}$ & 0.52 & 0.47 & 0.46 & 0.47 & 0.47 & 0.44 & 0.46 & 0.41 & 0.46 & $\mathrm{NC}$ \\
\hline F & 0.82 & 0.30 & 0.31 & 0.31 & $0.32^{\#}$ & 0.32 & 0.32 & 0.32 & $0.32^{\#}$ & NC \\
\hline $\mathrm{Fe}_{2} \mathrm{O}_{3}$ & 6.96 & 6.71 & 6.90 & 6.60 & 6.52 & 6.47 & 6.47 & 6.47 & 6.70 & -3.62 \\
\hline $\mathrm{K}_{2} \mathrm{O}$ & 0.46 & 0.48 & 0.47 & 0.48 & 0.48 & 0.45 & 0.44 & 0.48 & 0.49 & $\mathrm{NC}$ \\
\hline $\mathrm{Li}_{2} \mathrm{O}^{*}$ & 5.16 & 4.76 & 4.79 & 4.81 & 4.83 & 4.84 & 4.86 & 4.87 & $5.02^{\$}$ & -2.66 \\
\hline $\mathrm{MgO}$ & 0.43 & 0.54 & 0.53 & 0.57 & 0.52 & 0.51 & 0.48 & 0.49 & 0.44 & NC \\
\hline $\mathrm{MnO}$ & $\S$ & 0.03 & 0.02 & 0.02 & 0.03 & 0.02 & 0.02 & 0.02 & 0.02 & NC \\
\hline $\mathrm{Na}_{2} \mathrm{O}$ & 7.74 & 8.78 & 8.62 & 8.69 & 8.98 & 8.75 & 8.56 & 8.59 & 8.37 & 8.20 \\
\hline $\mathrm{NiO}$ & 1.93 & 1.67 & 1.70 & 1.65 & 1.69 & 1.62 & 1.53 & 1.65 & 1.69 & -12.21 \\
\hline $\mathrm{P}_{2} \mathrm{O}_{5}$ & 4.99 & 5.61 & 5.59 & 5.62 & 5.55 & 5.59 & 5.68 & 5.62 & 5.64 & 12.99 \\
\hline $\mathrm{PbO}$ & 0.25 & 0.26 & 0.26 & 0.26 & 0.25 & 0.24 & 0.26 & 0.25 & 0.26 & NC \\
\hline $\mathrm{SiO}_{2}$ & 29.25 & 30.03 & 30.13 & 30.29 & 30.22 & 30.43 & 30.55 & 30.50 & 30.00 & 2.57 \\
\hline $\mathrm{SO}_{3}$ & 0.48 & 0.29 & 0.27 & 0.30 & 0.29 & 0.30 & 0.29 & 0.31 & 0.30 & NC \\
\hline $\mathrm{SrO}$ & $\S$ & $<0.01$ & $<0.01$ & $<0.01$ & $<0.01$ & $<0.01$ & $<0.01$ & $<0.01$ & $<0.01$ & NC \\
\hline $\mathrm{TiO}_{2}$ & 0.16 & 0.26 & 0.29 & 0.27 & 0.27 & 0.27 & 0.29 & 0.30 & 0.30 & NC \\
\hline $\mathrm{ZnO}$ & 0.16 & 0.16 & 0.16 & 0.14 & 0.15 & 0.14 & 0.15 & 0.14 & 0.16 & NC \\
\hline $\mathrm{ZrO}_{2}$ & 0.21 & 0.19 & 0.18 & 0.18 & 0.17 & 0.18 & 0.18 & 0.17 & 0.18 & NC \\
\hline Sum & 100.00 & 100.00 & 100.00 & 100.00 & 100.00 & 100.00 & \begin{tabular}{|l|}
100.00 \\
\end{tabular} & \begin{tabular}{|l|}
100.00 \\
\end{tabular} & 100.00 & $\mathrm{NC}$ \\
\hline $\begin{array}{l}\text { * - Values ca } \\
\text { samples us } \\
\text { \$ - Not a targ } \\
\$ \text { - DCP-AE } \\
\text { \# - Analyzed } \\
\text { NC - Not cal }\end{array}$ & $\begin{array}{l}\text { ing a sin } \\
\text { get const } \\
\text { S result } \\
\text { l by XRI }\end{array}$ & $\begin{array}{l}\text { mple w } \\
\text { tituent }\end{array}$ & . & an & $\mathrm{s}$ by & $\mathrm{AE}$ & the $\mathrm{f}$ & isch & gla & $\mathrm{d} \mathrm{fe}$ \\
\hline
\end{tabular}


Table 4.5. XRF Analyzed Composition for Dip Samples Taken Before and After DM100 Melter Tests (wt\%).

\begin{tabular}{|c|c|c|c|c|c|c|c|}
\hline \multirow{3}{*}{\begin{tabular}{|c|} 
Formulation \\
Test \\
Constituent
\end{tabular}} & \multirow{2}{*}{ Before 1} & \multicolumn{3}{|c|}{ HLW-Bi-F3 } & \multicolumn{3}{|c|}{ HLW-Bi-F9 } \\
\hline & & \multirow{2}{*}{ Target } & After 1 & After 2 & \multirow{2}{*}{ Target } & After 3 & \multirow{2}{*}{\begin{tabular}{|c|} 
After 4 \\
LBL-D-74A
\end{tabular}} \\
\hline & KBL-D-103A & & KBL-D-127A & LBL-D-8A & & LBL-D-50A & \\
\hline $\mathrm{Al}_{2} \mathrm{O}_{3}$ & 11.15 & 11.65 & 11.94 & 11.51 & 16.65 & 15.35 & 15.68 \\
\hline $\mathrm{B}_{2} \mathrm{O}_{3}$ & $11.06^{*}$ & 10.29 & $9.80^{*}$ & $9.60^{*}$ & 16.29 & $14.88^{*}$ & $15.66^{*}$ \\
\hline $\mathrm{BaO}$ & 0.04 & 0.01 & 0.01 & 0.02 & 0.01 & $<0.01$ & 0.04 \\
\hline $\mathrm{Bi}_{2} \mathrm{O}_{3}$ & 6.76 & 6.71 & 7.13 & 7.48 & 6.71 & 7.10 & 7.04 \\
\hline $\mathrm{CaO}$ & 0.85 & 0.84 & 0.81 & 0.85 & 0.84 & 0.78 & 0.79 \\
\hline $\mathrm{CdO}$ & 0.02 & $\S$ & 0.01 & $<0.01$ & $\S$ & $<0.01$ & $<0.01$ \\
\hline $\mathrm{Cl}$ & 0.03 & $\S$ & 0.01 & 0.01 & $\S$ & 0.01 & 0.01 \\
\hline $\mathrm{Cr}_{2} \mathrm{O}_{3}$ & 0.41 & 0.52 & 0.53 & 0.51 & 0.52 & 0.47 & 0.50 \\
\hline $\mathrm{F}$ & $0.34^{*}$ & 0.82 & $0.43^{*}$ & $0.43^{*}$ & 0.82 & $0.33^{*}$ & $0.32^{*}$ \\
\hline $\mathrm{Fe}_{2} \mathrm{O}_{3}$ & 7.94 & 6.96 & 7.63 & 7.27 & 6.96 & 7.01 & 6.85 \\
\hline $\mathrm{K}_{2} \mathrm{O}$ & 0.35 & 0.46 & 0.31 & 0.48 & 0.46 & 0.52 & 0.50 \\
\hline $\mathrm{Li}_{2} \mathrm{O}$ & $0.39^{*}$ & 0.16 & $0.25^{*}$ & $0.26^{*}$ & 5.16 & $4.27^{*}$ & $5.02^{*}$ \\
\hline $\mathrm{MgO}$ & 0.41 & 0.43 & 0.44 & 0.51 & 0.43 & 0.55 & 0.43 \\
\hline $\mathrm{MnO}$ & 0.27 & $\S$ & 0.10 & 0.06 & $\S$ & 0.03 & 0.02 \\
\hline $\mathrm{Na}_{2} \mathrm{O}$ & 16.66 & 18.73 & 17.17 & 18.06 & 7.74 & 9.78 & 8.54 \\
\hline $\mathrm{NiO}$ & 1.65 & 1.93 & 2.05 & 2.06 & 1.93 & 1.89 & 1.88 \\
\hline $\mathrm{P}_{2} \mathrm{O}_{5}$ & 4.99 & 4.99 & 5.30 & 5.25 & 4.99 & 5.54 & 5.57 \\
\hline $\mathrm{PbO}$ & 0.40 & 0.25 & 0.27 & 0.27 & 0.25 & 0.25 & 0.24 \\
\hline $\mathrm{SiO}_{2}$ & 34.93 & \begin{tabular}{|l}
34.24 \\
\end{tabular} & 34.75 & 34.36 & \begin{tabular}{|l|}
29.25 \\
\end{tabular} & 30.27 & 30.02 \\
\hline $\mathrm{SO}_{3}$ & 0.47 & 0.48 & 0.39 & 0.36 & 0.48 & 0.35 & 0.29 \\
\hline $\mathrm{SrO}$ & 0.04 & $\S$ & 0.02 & 0.01 & $\S$ & $<0.01$ & $<0.01$ \\
\hline $\mathrm{TiO}_{2}$ & 0.19 & 0.16 & 0.17 & 0.17 & 0.16 & 0.26 & 0.28 \\
\hline $\mathrm{ZnO}$ & 0.18 & 0.16 & 0.17 & 0.15 & 0.16 & 0.16 & 0.15 \\
\hline $\mathrm{ZrO}_{2}$ & 0.48 & 0.21 & 0.33 & 0.31 & 0.21 & 0.19 & 0.18 \\
\hline Sum & 100.00 & 100.00 & 100.00 & 100.00 & 100.00 & 100.00 & 100.00 \\
\hline
\end{tabular}

$\S$ - Not a target constituent

* - Value from DCP-AES analysis of contemporaneous discharge glass 
Table 4.6. PCT Results for Melter and Crucible Glasses (ASTM C1285, 7-days at $90^{\circ} \mathrm{C}$, Stainless Steel Vessel; S/V=2000 $\left.\mathrm{m}^{-1}\right)$.

\begin{tabular}{|c|c|c|c|c|c|c|}
\hline \multirow{2}{*}{\multicolumn{2}{|c|}{$\begin{array}{c}\text { Composition } \\
\text { Glass Samples }\end{array}$}} & \multicolumn{2}{|c|}{ HLW-Bi-F3 } & \multicolumn{2}{|c|}{ HLW-Bi-F9 } & \multirow{3}{*}{$\begin{array}{c}\text { DWPF- } \\
\text { EA } \\
615\end{array}$} \\
\hline & & \multirow{2}{*}{$\begin{array}{c}\begin{array}{c}\text { Melter Glass } \\
\text { LBL-G-8A }\end{array} \\
15.67\end{array}$} & \multirow{2}{*}{$\begin{array}{l}\text { Crucible } \\
\text { Melt [2] } \\
-\end{array}$} & \multirow{2}{*}{$\begin{array}{c}\begin{array}{c}\text { Melter Glass } \\
\text { LBL-G-71C }\end{array} \\
90.40\end{array}$} & \multirow{2}{*}{$\begin{array}{c}\text { Crucible } \\
\text { Melt [2] } \\
-\end{array}$} & \\
\hline \multirow{4}{*}{$\begin{array}{c}\text { 7-Day PCT } \\
\text { Concentration in } \\
\text { mg/L }\end{array}$} & $\mathrm{B}$ & & & & & \\
\hline & $\mathrm{Li}$ & $<0.01$ & - & 42.41 & - & 201 \\
\hline & $\mathrm{Na}$ & 90.74 & - & 53.36 & - & 1582 \\
\hline & $\mathrm{Si}$ & 45.44 & - & 57.56 & - & 910 \\
\hline \multirow{5}{*}{$\begin{array}{c}\text { 7-Day PCT } \\
\text { Normalized } \\
\text { Concentrations, } \\
\text { g/L }\end{array}$} & $\mathrm{B}$ & 0.53 & 0.92 & 1.86 & 3.11 & 18.16 \\
\hline & $\mathrm{Li}$ & $<0.01$ & 0.32 & 1.82 & 1.90 & 10.31 \\
\hline & $\mathrm{Na}$ & 0.65 & 0.81 & 0.86 & 1.31 & 13.08 \\
\hline & $\mathrm{Si}$ & 0.29 & - & 0.41 & - & 4.20 \\
\hline & $\mathrm{pH}$ & 10.11 & - & 9.21 & - & 11.95 \\
\hline \multirow{4}{*}{$\begin{array}{c}\text { 7-Day PCT } \\
\text { Normalized Mass } \\
\text { Loss }\left(\mathrm{g} / \mathrm{m}^{2}\right)\end{array}$} & $\mathrm{B}$ & 0.26 & - & 0.93 & - & 9.08 \\
\hline & $\mathrm{Li}$ & $<0.01$ & - & 0.91 & - & 5.16 \\
\hline & $\mathrm{Na}$ & 0.33 & - & 0.43 & - & 6.54 \\
\hline & $\mathrm{Si}$ & 0.14 & - & 0.21 & - & 2.10 \\
\hline \multirow{4}{*}{$\begin{array}{c}\text { 7-Day PCT } \\
\text { Normalized Loss } \\
\text { Rate, } \mathrm{g} / \mathrm{d} / \mathrm{m}^{2}\end{array}$} & $\mathrm{~B}$ & 0.04 & - & 0.13 & - & 1.30 \\
\hline & $\mathrm{Li}$ & $<0.01$ & - & 0.13 & - & 0.74 \\
\hline & $\mathrm{Na}$ & 0.05 & - & 0.06 & - & 0.93 \\
\hline & $\mathrm{Si}$ & 0.02 & - & 0.03 & - & 0.30 \\
\hline
\end{tabular}

- Empty data field 
ORP-56288 Rev. 0

The Catholic University of America

Vitreous State Laboratory
Melter Testing of New High Bismuth HLW Formulations Final Report, VSL-13R2770-1, Rev. 0

Table 4.7. TCLP Results for Melter and Crucible Glasses (mg/L).

\begin{tabular}{|c|c|c|c|c|c|c|c|c|}
\hline \multirow{2}{*}{ Test } & Element & $\mathrm{Ba}$ & $\mathrm{Bi}$ & $\mathrm{Cd}$ & $\mathrm{Cr}$ & $\mathrm{Ni}$ & $\mathrm{Pb}$ & $\mathrm{Zn}$ \\
\cline { 2 - 8 } & UTS Limits $^{\#}$ & 21 & $\mathrm{NA}$ & 0.11 & 0.60 & 11.00 & 0.75 & 4.3 \\
\cline { 2 - 9 } & Delisting Limits & 100 & $\mathrm{NA}$ & 0.480 & 4.95 & 22.6 & 5.00 & 225 \\
\hline \multirow{2}{*}{$\begin{array}{c}\text { HLW- } \\
\text { Bi-F3 }\end{array}$} & $\begin{array}{c}\text { Melter Glass } \\
\text { LBL-G-8A }\end{array}$ & 0.01 & 0.51 & $<0.03$ & 0.09 & 0.46 & 0.13 & 0.06 \\
\cline { 2 - 9 } & Crucible Melt [2] & 0.07 & 0.71 & $\mathrm{NA}$ & 0.08 & 0.44 & $<0.1$ & $\mathrm{NA}$ \\
\hline \multirow{2}{*}{$\begin{array}{c}\text { HLW- } \\
\text { Bi-F9 }\end{array}$} & $\begin{array}{c}\text { Melter Glass } \\
\text { LBL-G-71C }\end{array}$ & $<0.01$ & 0.93 & $<0.03$ & 0.01 & 0.05 & 0.15 & 0.07 \\
\cline { 2 - 9 } & Crucible Melt [2] & 0.10 & 1.12 & NA & $<0.01$ & $<0.04$ & $<0.1$ & 0.08 \\
\hline
\end{tabular}

\# For comparison only; does not apply to WTP glasses

NA: Not analyzed 
Table 5.1. Results from DM100 Off-Gas Emission Samples.

\begin{tabular}{|c|c|c|c|c|c|c|c|c|c|}
\hline & & \multicolumn{4}{|c|}{$\begin{array}{c}\text { Test } 1 \\
\text { Optimized Bubbling }\end{array}$} & \multicolumn{4}{|c|}{$\begin{array}{c}\text { Test } 2 \\
\text { Fixed Bubbling }(9 \mathrm{lpm})\end{array}$} \\
\hline & & \multicolumn{4}{|c|}{$\begin{array}{c}\text { 08/22/2012 10:44 - 11:44 } \\
11.2 \% \text { Moisture, 96.42\% Isokinetic }\end{array}$} & \multicolumn{4}{|c|}{$\begin{array}{c}\text { 08/24/2012 12:05 - 13:05 } \\
\text { 9.83\% Moisture, 96.46\% Isokinetic }\end{array}$} \\
\hline & & $\begin{array}{c}\text { Feed }^{\#} \\
(\mathrm{mg} / \mathrm{min})\end{array}$ & $\begin{array}{c}\text { Output } \\
\text { (mg/min) }\end{array}$ & $\%$ Emitted & $\mathrm{DF}$ & $\begin{array}{c}\text { Feed }^{\#} \\
(\mathrm{mg} / \mathrm{min})\end{array}$ & $\begin{array}{c}\text { Output } \\
\text { (mg/min) }\end{array}$ & $\%$ Emitted & DF \\
\hline \multirow{21}{*}{ 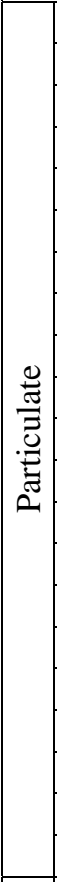 } & Total $^{\$}$ & 73580 & 218 & 0.30 & 338 & 62128 & 243 & 0.39 & 256 \\
\hline & $\mathrm{Al}$ & 13365 & 4.00 & 0.03 & 3339 & 9869 & 3.99 & 0.04 & 2475 \\
\hline & B & 6926 & 6.82 & 0.10 & 1016 & 5114 & 8.39 & 0.16 & 609 \\
\hline & $\mathrm{Ba}$ & 19 & $<0.10$ & $<0.52$ & $>194$ & 14 & $<0.10$ & $<0.70$ & $>143$ \\
\hline & $\mathrm{Bi}$ & 13041 & 10.51 & 0.08 & 1241 & 9630 & 12.8 & 0.13 & 755 \\
\hline & $\mathrm{Ca}$ & 1301 & 0.94 & 0.07 & 1386 & 961 & 1.27 & 0.13 & 756 \\
\hline & $\mathrm{Cr}$ & 771 & 3.02 & 0.39 & 256 & 569 & 2.96 & 0.52 & 193 \\
\hline & $\mathrm{F}^{*}$ & 1777 & 12.7 & 0.72 & 140 & 1312 & 16.7 & 1.27 & 130 \\
\hline & $\mathrm{Fe}$ & 10545 & 4.80 & 0.05 & 2196 & 7787 & 6.55 & 0.08 & 1189 \\
\hline & $\mathrm{K}$ & 827 & 3.40 & 0.41 & 243 & 611 & 3.17 & 0.52 & 193 \\
\hline & $\mathrm{Li}$ & 161 & 0.23 & 0.14 & 708 & 119 & 0.19 & 0.16 & 613 \\
\hline & $\mathrm{Mg}$ & 562 & 0.63 & 0.11 & 895 & 415 & 0.80 & 0.19 & 521 \\
\hline & $\mathrm{Na}$ & 30125 & 42.6 & 0.14 & 708 & 22246 & 44.0 & 0.20 & 506 \\
\hline & $\mathrm{Ni}$ & 3286 & 1.82 & 0.06 & 1803 & 2427 & 2.54 & 0.10 & 956 \\
\hline & $\mathrm{P}$ & 4721 & 1.89 & 0.04 & 2496 & 3486 & 2.23 & 0.06 & 1566 \\
\hline & $\mathrm{Pb}$ & 503 & 0.55 & 0.11 & 910 & 371 & 0.53 & 0.14 & 698 \\
\hline & $\mathrm{S}^{*}$ & 417 & 25.3 & 6.07 & 16.5 & 308 & 20.6 & 6.68 & 15.0 \\
\hline & $\mathrm{Si}$ & 34700 & 9.12 & 0.03 & 3803 & 25625 & 14.6 & 0.06 & 1750 \\
\hline & $\mathrm{Ti}$ & 208 & 0.20 & 0.09 & 1060 & 153 & 0.24 & 0.16 & 629 \\
\hline & $\mathrm{Zn}$ & 279 & 0.18 & 0.07 & 1524 & 206 & 0.21 & 0.10 & 1001 \\
\hline & $\mathrm{Zr}$ & 337 & $<0.10$ & $<0.03$ & $>3368$ & 249 & 0.15 & 0.06 & 1706 \\
\hline \multirow{3}{*}{ 怘 } & B & 6926 & 17.6 & 0.25 & 393 & 5114 & 17.9 & 0.35 & 285 \\
\hline & $F$ & 1777 & 104 & 5.84 & 17.1 & 1312 & 148 & 11.3 & 8.9 \\
\hline & $\mathrm{S}$ & 417 & 18.6 & 4.47 & 22.4 & 308 & 12.4 & 4.03 & 24.8 \\
\hline
\end{tabular}

\$ From gravimetric analysis of filters and particulate nitric acid rinses

* - Feed rate calculated from target composition and total glass production rate

* - Calculated from analysis of filter particulate by water dissolution and analysis of particulate rinse 
Table 5.1. Results from DM100 Off-Gas Emission Samples (continued).

\begin{tabular}{|c|c|c|c|c|c|c|c|c|c|}
\hline & & \multicolumn{4}{|c|}{$\begin{array}{c}\text { Test } 3 \\
\text { Optimized Bubbling }\end{array}$} & \multicolumn{4}{|c|}{$\begin{array}{c}\text { Test } 4 \\
\text { Fixed Bubbling }(9 \mathrm{lpm})\end{array}$} \\
\hline & & \multicolumn{4}{|c|}{$\begin{array}{c}\text { 08/28/2012 21:05 - 22:05 } \\
\text { 19.8\% Moisture, 98.90\% Isokinetic }\end{array}$} & \multicolumn{4}{|c|}{$\begin{array}{c}\text { 08/30/2012 17:19 - 18:19 } \\
\text { 17.7\% Moisture, 97.95\% Isokinetic }\end{array}$} \\
\hline & & $\begin{array}{c}\text { Feed }^{\#} \\
(\mathrm{mg} / \mathrm{min})\end{array}$ & $\begin{array}{c}\text { Output } \\
\text { (mg/min) }\end{array}$ & $\%$ Emitted & DF & $\begin{array}{c}\text { Feed }^{\#} \\
(\mathrm{mg} / \mathrm{min})\end{array}$ & $\begin{array}{c}\text { Output } \\
\text { (mg/min) }\end{array}$ & $\%$ Emitted & DF \\
\hline \multirow{21}{*}{ 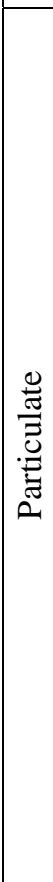 } & Total $^{\$}$ & 145188 & 264 & 0.18 & 549 & 138341 & 243 & 0.18 & 571 \\
\hline & $\mathrm{Al}$ & 31728 & 3.88 & 0.01 & 8174 & 30113 & 3.39 & 0.01 & 8892 \\
\hline & B & 18211 & 11.84 & 0.07 & 1538 & 17284 & 11.82 & 0.07 & 1462 \\
\hline & $\mathrm{Ba}$ & 32 & $<0.10$ & $<0.31$ & $>322$ & 31 & $<0.10$ & $<0.33$ & $>306$ \\
\hline & $\mathrm{Bi}$ & 21668 & 18.0 & 0.08 & 1204 & 20564 & 17.7 & 0.09 & 1163 \\
\hline & $\mathrm{Ca}$ & 2162 & 1.24 & 0.06 & 1738 & 2051 & 1.17 & 0.06 & 1760 \\
\hline & $\mathrm{Cr}$ & 1281 & 2.11 & 0.16 & 606 & 1216 & 1.39 & 0.11 & 876 \\
\hline & $\mathrm{F}^{*}$ & 2952 & 17.7 & 0.60 & 167 & 2802 & 7.80 & 0.28 & 359 \\
\hline & $\mathrm{Fe}$ & 17520 & 5.38 & 0.03 & 3259 & 16628 & 10.2 & 0.36 & 275 \\
\hline & $\mathrm{K}$ & 1375 & 4.03 & 0.29 & 342 & 1305 & 3.61 & 0.28 & 362 \\
\hline & $\mathrm{Li}$ & 8629 & 7.79 & 0.09 & 1108 & 8190 & 7.65 & 0.09 & 1071 \\
\hline & $\mathrm{Mg}$ & 933 & 0.28 & 0.03 & 3300 & 886 & 0.29 & 0.03 & 3094 \\
\hline & $\mathrm{Na}$ & 20673 & 31.2 & 0.15 & 663 & 19620 & 26.0 & 0.13 & 754 \\
\hline & $\mathrm{Ni}$ & 5460 & 2.16 & 0.04 & 2523 & 5182 & 1.77 & 0.03 & 2935 \\
\hline & $\mathrm{P}$ & 7843 & 1.84 & 0.02 & 4266 & 7444 & 1.98 & 0.03 & 3761 \\
\hline & $\mathrm{Pb}$ & 835 & 0.98 & 0.12 & 849 & 792.9 & 0.88 & 0.11 & 904 \\
\hline & $\mathrm{S}^{*}$ & 692 & 32.7 & 4.72 & 21.2 & 657 & 25.9 & 3.94 & 25.4 \\
\hline & $\mathrm{Si}$ & 49241 & 17.3 & 0.04 & 2843 & 46733 & 14.8 & 0.03 & 3158 \\
\hline & $\mathrm{Ti}$ & 345 & 0.29 & 0.08 & 1204 & 328 & 0.25 & 0.08 & 1313 \\
\hline & $\mathrm{Zn}$ & 463 & 0.21 & 0.05 & 2197 & 439 & 0.16 & 0.04 & 2727 \\
\hline & $\mathrm{Zr}$ & 560 & $<0.10$ & $<0.02$ & $>5597$ & 531 & $<0.10$ & $<0.02$ & $>5312$ \\
\hline \multirow{3}{*}{ 㞼 } & B & 18211 & 126 & 0.69 & 144 & 17284 & 139 & 0.81 & 124 \\
\hline & $\mathrm{F}$ & 2952 & 293 & 9.92 & 10.1 & 2802 & 303 & 10.8 & 9.2 \\
\hline & $\mathrm{S}$ & 692 & 100 & 14.5 & 6.9 & 657 & 106 & 16.1 & 6.2 \\
\hline
\end{tabular}

$\$$ - From gravimetric analysis of filters and particulate nitric acid rinses

\# - Feed rate calculated from target composition and total glass production rate

* - Calculated from analysis of filter particulate by water dissolution and analysis of particulate rinse 
ORP-56288 Rev. 0

The Catholic University of America

Vitreous State Laboratory
Melter Testing of New High Bismuth HLW Formulations

Final Report, VSL-13R2770-1, Rev. 0

Table 5.2. Concentrations (ppmv) of Selected Species in DM100 Exhaust Measured by FTIR Spectroscopy.

\begin{tabular}{|c|c|c|c|c|c|c|c|c|}
\hline \multirow{2}{*}{ Test } & \multicolumn{2}{|c|}{$\mathbf{1}$} & \multicolumn{2}{c|}{$\mathbf{2}$} & \multicolumn{2}{c|}{3} & \multicolumn{2}{c|}{$\mathbf{4}$} \\
\cline { 2 - 9 } & Avg. & Range & Avg. & Range & Avg. & Range & Avg. & Range \\
\hline $\mathrm{N}_{2} \mathrm{O}$ & $<1.0$ & $<1.0-1.8$ & $<1.0$ & $<1.0-1.8$ & $<1.0$ & $<1.0-2.6$ & $<1.0$ & $<1.0-2.5$ \\
\hline $\mathrm{NO}$ & 110 & $1.1-621$ & 89.0 & $27.0-734$ & 168 & $1.8-636$ & 161 & $32.7-446$ \\
\hline $\mathrm{NO}_{2}$ & 11.2 & $1.0-84.4$ & 7.9 & $2.0-93.3$ & 25.2 & $<1.0-83.5$ & 21.7 & $1.7-70.0$ \\
\hline $\mathrm{NH}_{3}$ & $<1.0$ & $<1.0-1.9$ & 1.6 & $<1.0-2.7$ & 1.1 & $<1.0-4.4$ & 2.1 & $<1.0-4.9$ \\
\hline $\mathrm{H}_{2} \mathrm{O}[\%]$ & 6.4 & $1.9-18.7$ & 5.4 & $1.9-14.4$ & 9.8 & $1.9-19.3$ & 9.2 & $1.7-15.9$ \\
\hline $\mathrm{CO}_{2}$ & 1124 & $391-5964$ & 987 & $573-6485$ & 2044 & $428-5195$ & 1904 & $529-4507$ \\
\hline Nitrous Acid & $<1.0$ & $<1.0-1.5$ & $<1.0$ & $<1.0-1.4$ & $<1.0$ & $<1.0-1.6$ & $<1.0$ & $<1.0-1.1$ \\
\hline Nitric Acid & 1.1 & $<1.0-9.0$ & 1.2 & $<1.0-12.8$ & $<1.0$ & $<1.0-3.5$ & $<1.0$ & $<1.0-3.2$ \\
\hline $\mathrm{HCN}$ & $<1.0$ & NA & $<1.0$ & NA & $<1.0$ & NA & $<1.0$ & NA \\
\hline Acetonitrile & $<1.0$ & NA & $<1.0$ & NA & $<1.0$ & NA & $<1.0$ & NA \\
\hline $\mathrm{CO}$ & $<1.0$ & $<1.0-2.6$ & $<1.0$ & $<1.0-2.1$ & $<1.0$ & $<1.0-1.7$ & $<1.0$ & $<1.0-1.8$ \\
\hline $\mathrm{HCl}$ & 1.4 & $<1.0-10.7$ & 1.5 & $<1.0-9.3$ & 4.0 & $<1.0-15.4$ & 2.7 & $1.2-14.9$ \\
\hline $\mathrm{HF}$ & 28.1 & $6.5-59.9$ & 40.7 & $16.3-67.9$ & 79.0 & $40.5-240$ & 102 & $80.7-309$ \\
\hline
\end{tabular}

NA: Not applicable. 
ORP-56288 Rev. 0

The Catholic University of America

Vitreous State Laboratory
Melter Testing of New High Bismuth HLW Formulations Final Report, VSL-13R2770-1, Rev. 0

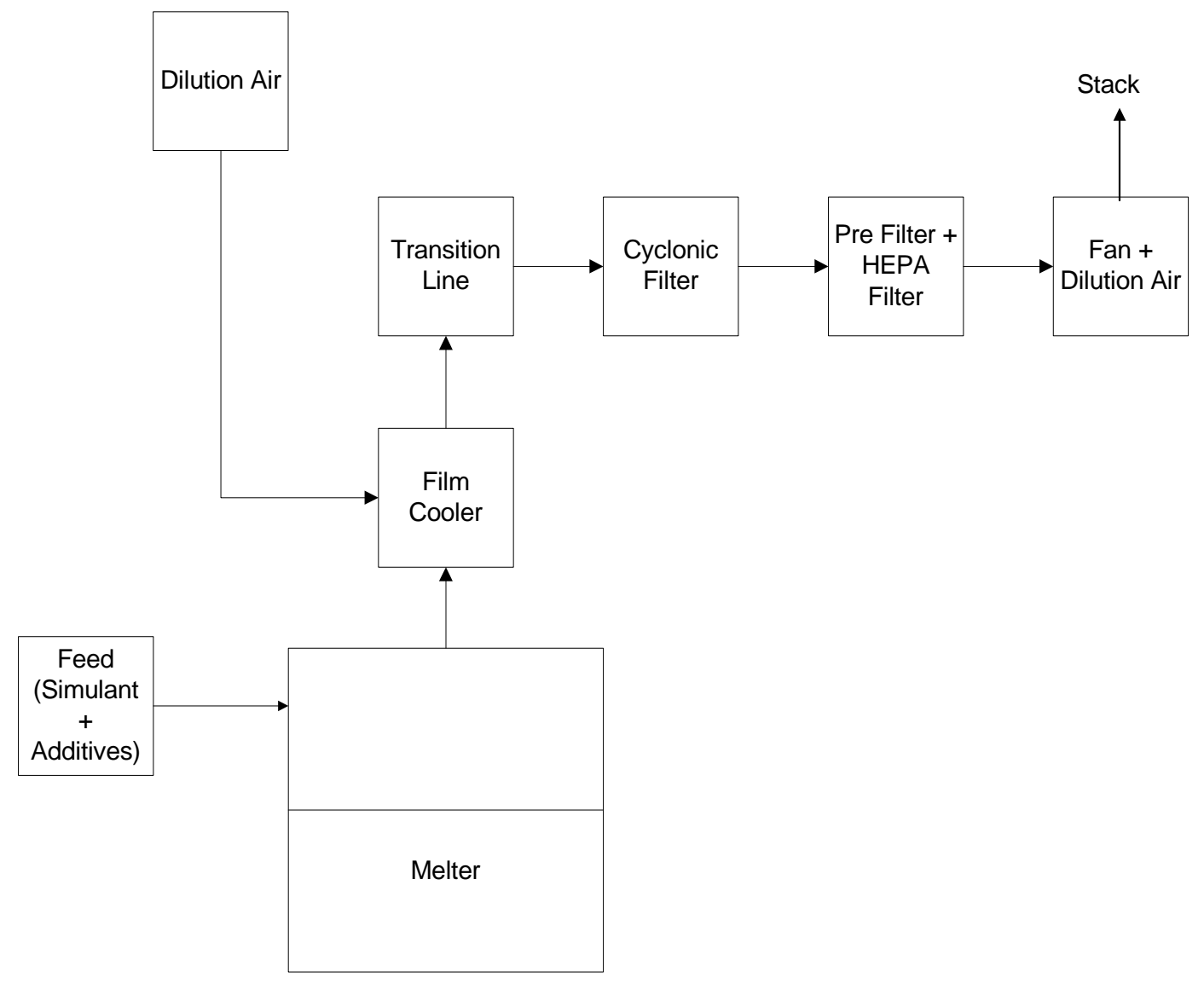

Figure 1.1. Schematic diagram of DuraMelter 100 vitrification system. 
ORP-56288 Rev. 0

The Catholic University of America

Vitreous State Laboratory
Melter Testing of New High Bismuth HLW Formulations Final Report, VSL-13R2770-1, Rev. 0

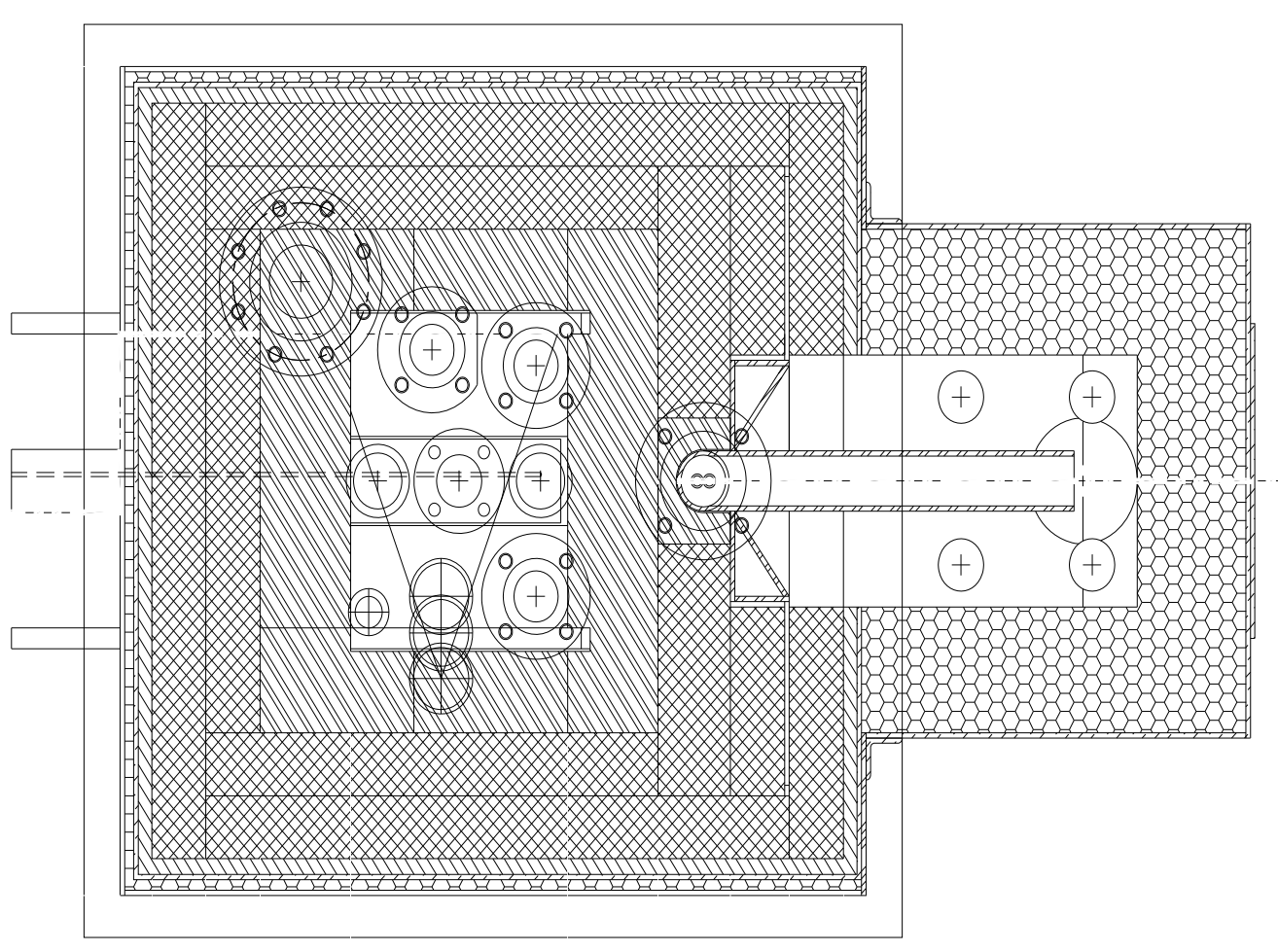

Figure 1.2.a. Schematic diagram showing cross-section through the DM100-BL-melter. Plan view showing locations of lid ports. 
ORP-56288 Rev. 0

The Catholic University of America

Vitreous State Laboratory
Melter Testing of New High Bismuth HLW Formulations Final Report, VSL-13R2770-1, Rev. 0

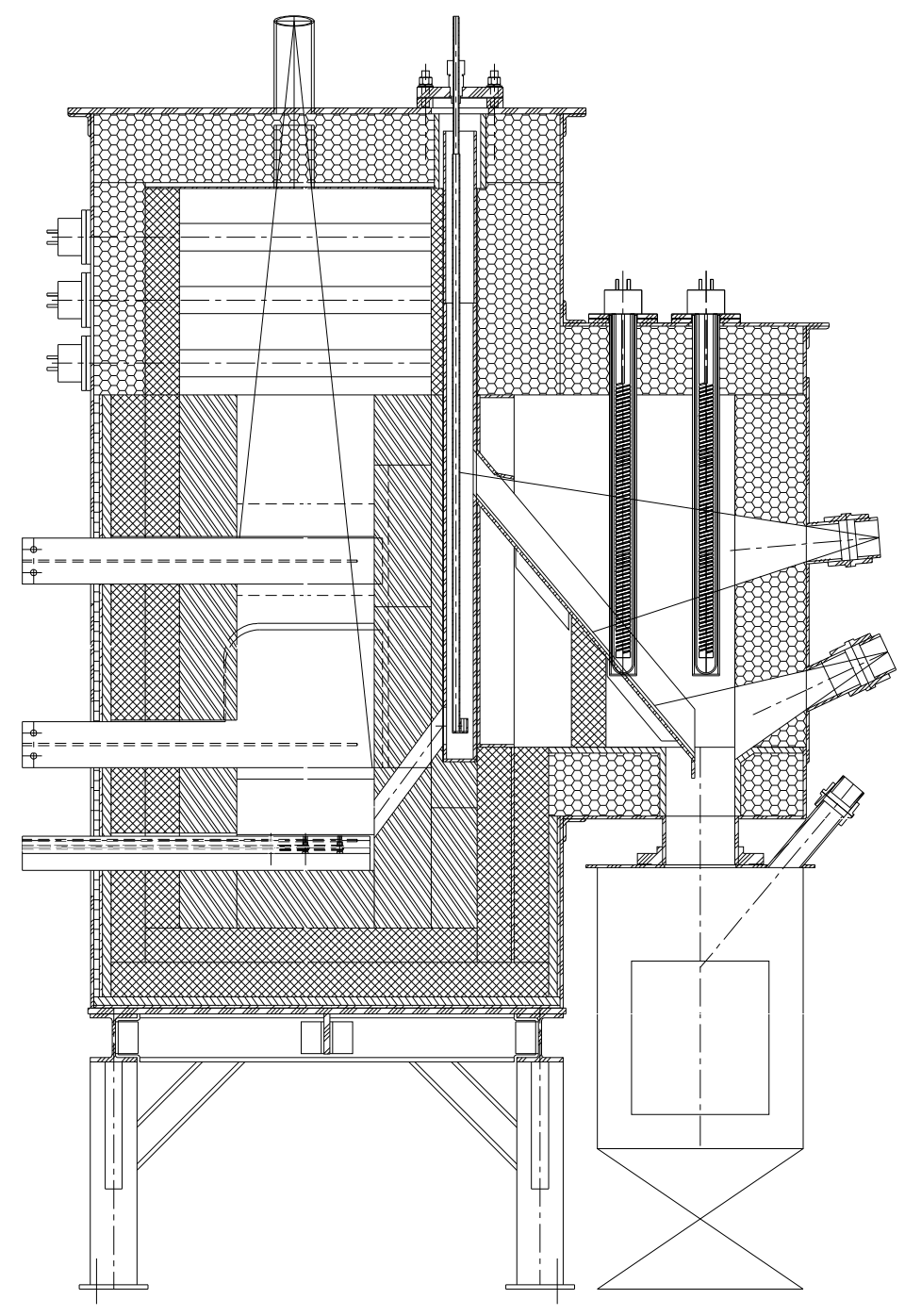

Figure 1.2.b. Schematic diagram showing cross-section through the DM100-BL melter. 
ORP-56288 Rev. 0

The Catholic University of America

Vitreous State Laboratory
Melter Testing of New High Bismuth HLW Formulations Final Report, VSL-13R2770-1, Rev. 0

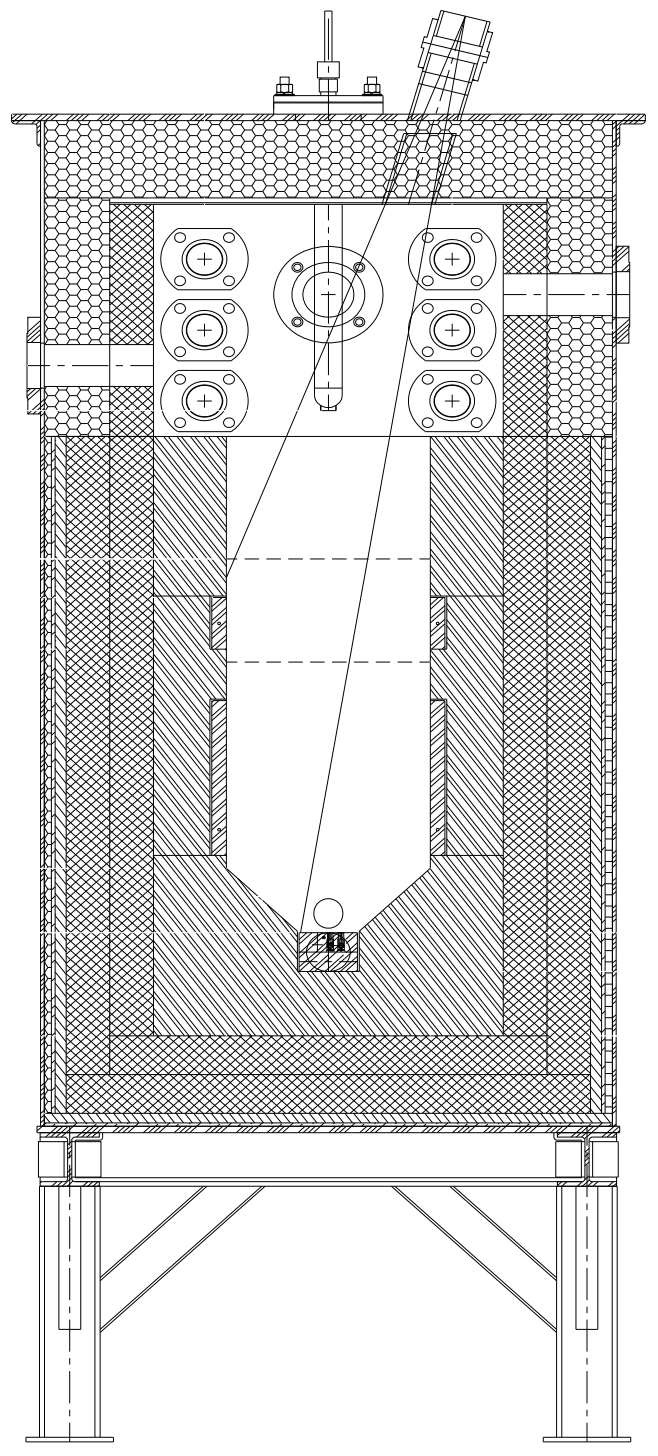

Figure 1.2.c. Schematic diagram showing cross-section through the DM100-BL melter. 


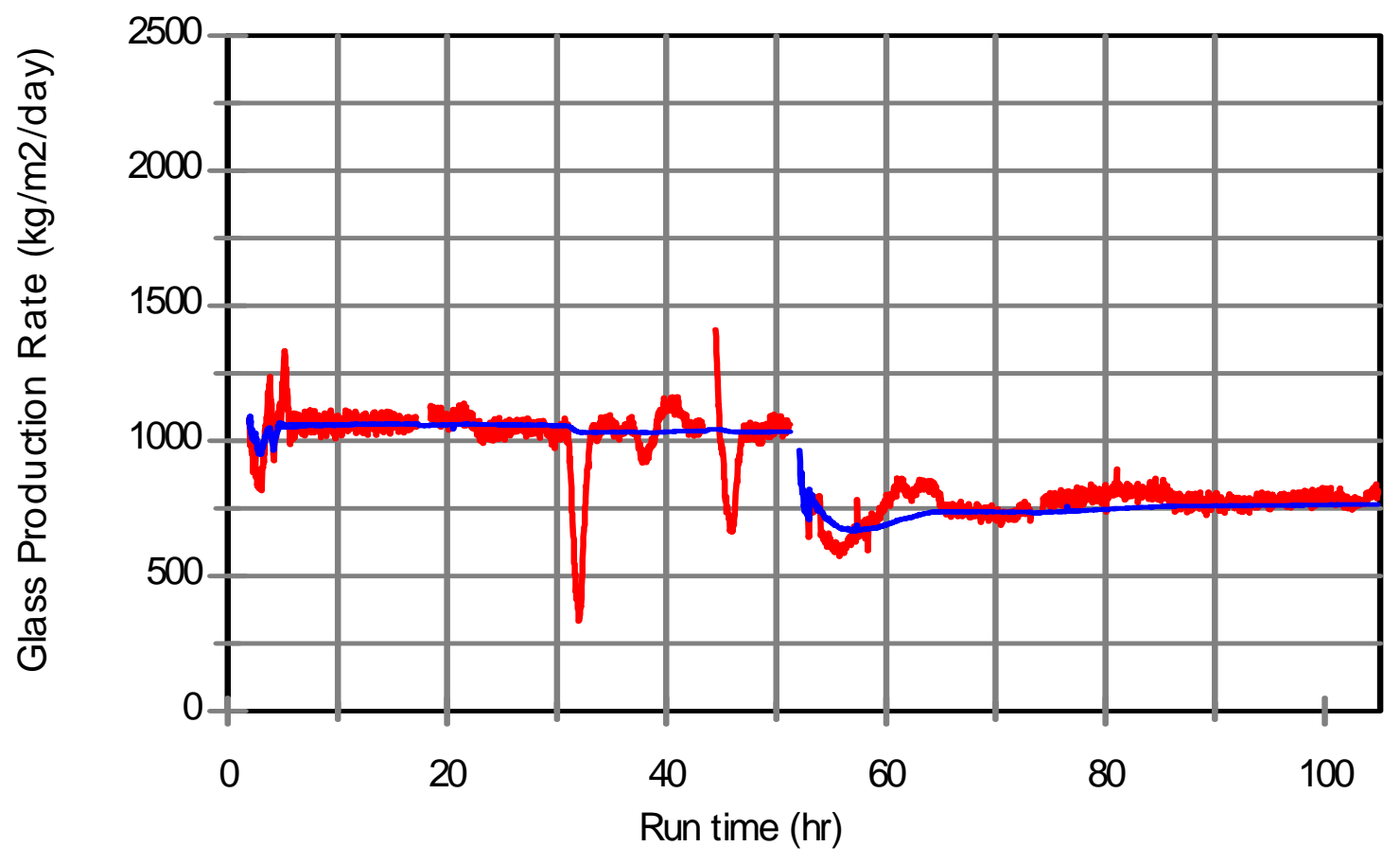

$1 \mathrm{hr}$ Moving Avg.

Cumulative

Figure 3.1.a. Glass production rates (hourly moving averages and cumulative) for DM100 test with HLW-Bi-F3 glass composition. 


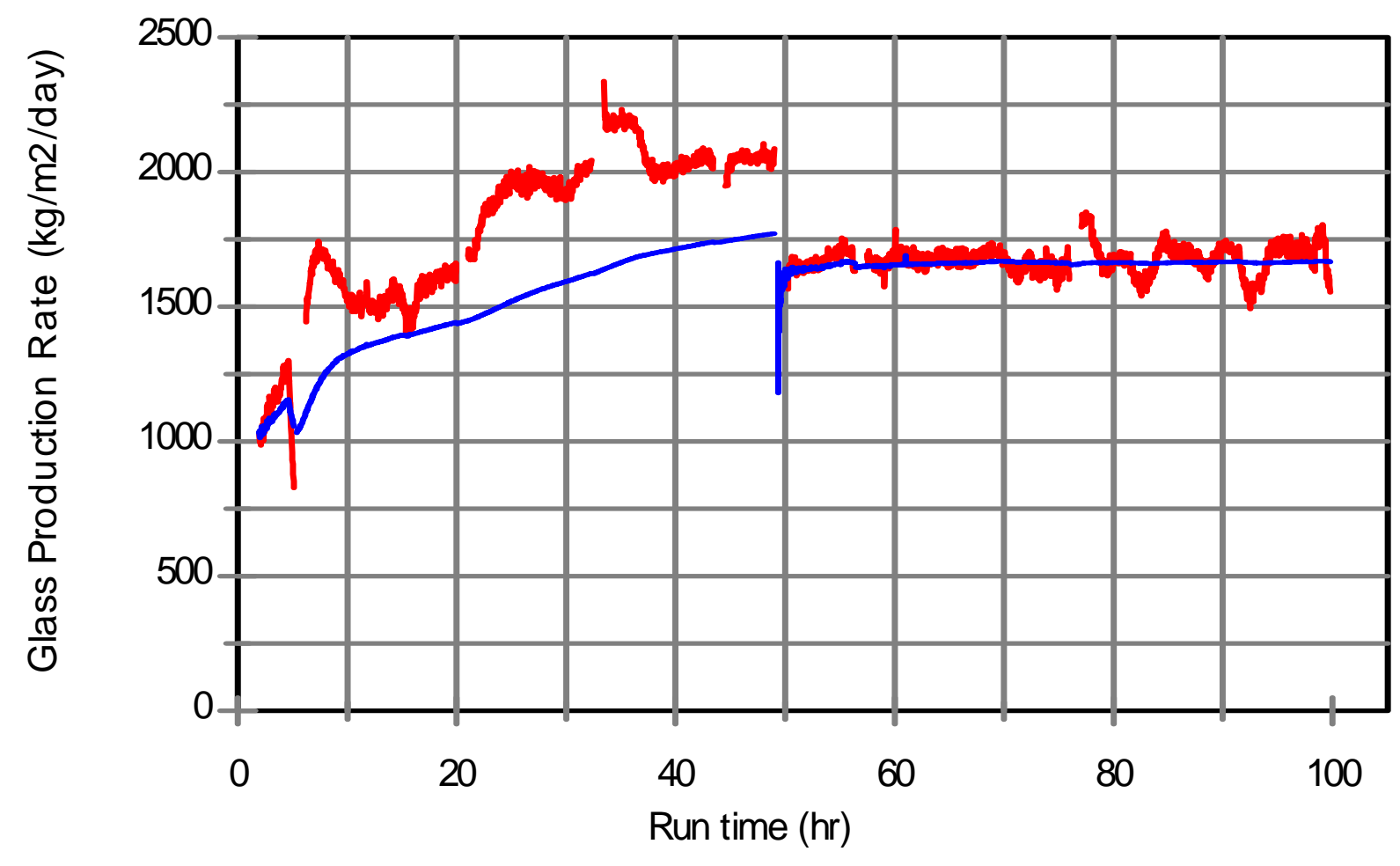

Figure 3.1.b. Glass production rates (hourly moving averages and cumulative) for DM100 test with HLW-Bi-F9 glass composition. 


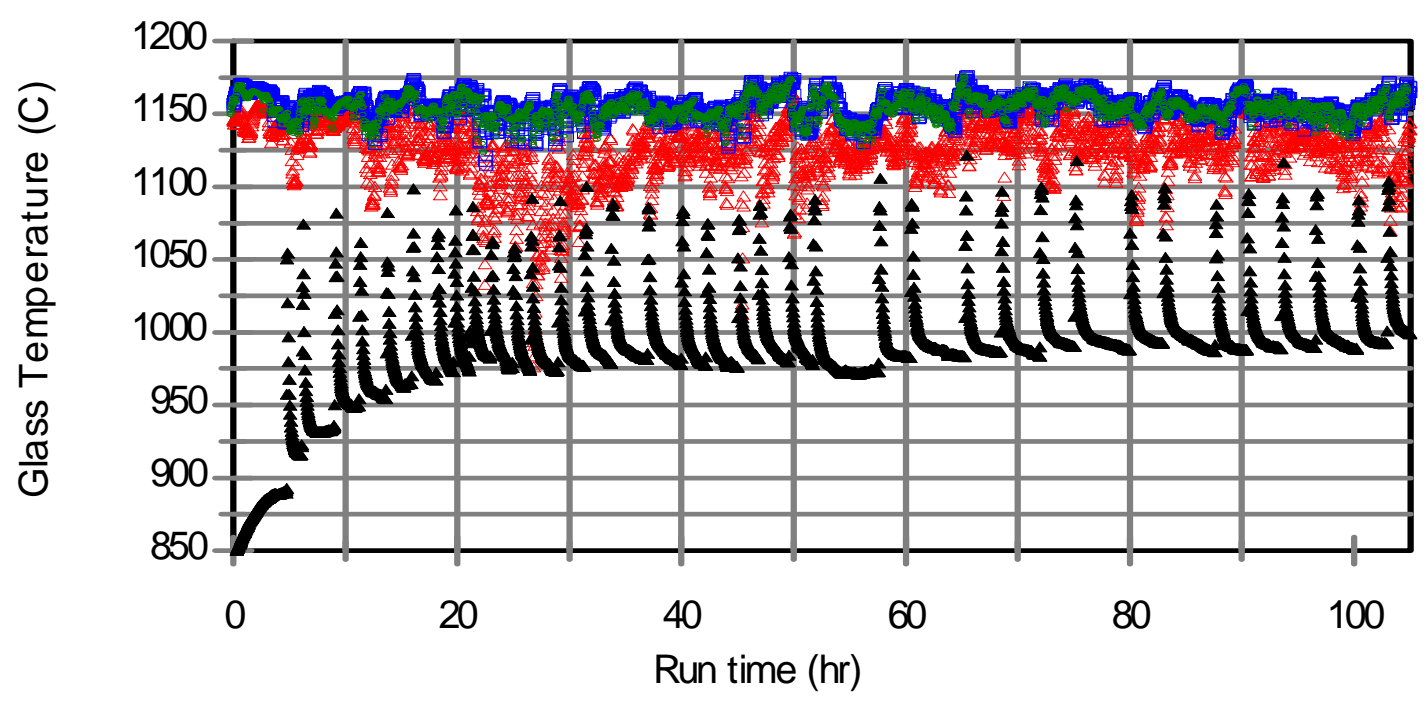

$\Delta \quad 27$ " from bottom

a 10 " from bottom

- Airlift
- 16 " from bottom

- $\quad 5^{\prime \prime}$ from bottom

Figure 3.2.a. Glass temperatures (hourly averages) during DM100 test with HLW-Bi-F3 glass composition. 


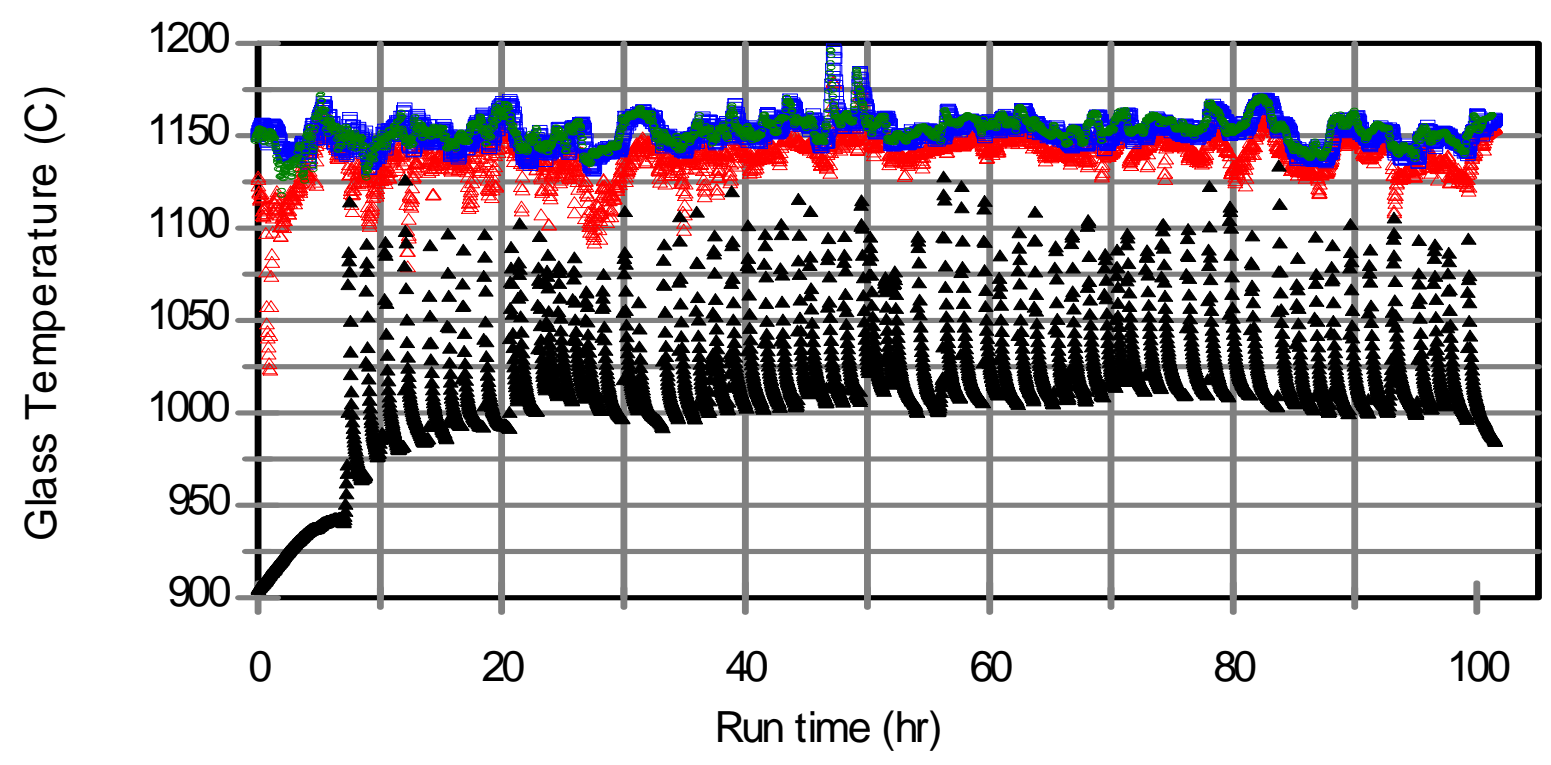

Figure 3.2.b. Glass temperatures (hourly averages) during DM100 test with HLW-Bi-F9 glass composition. 


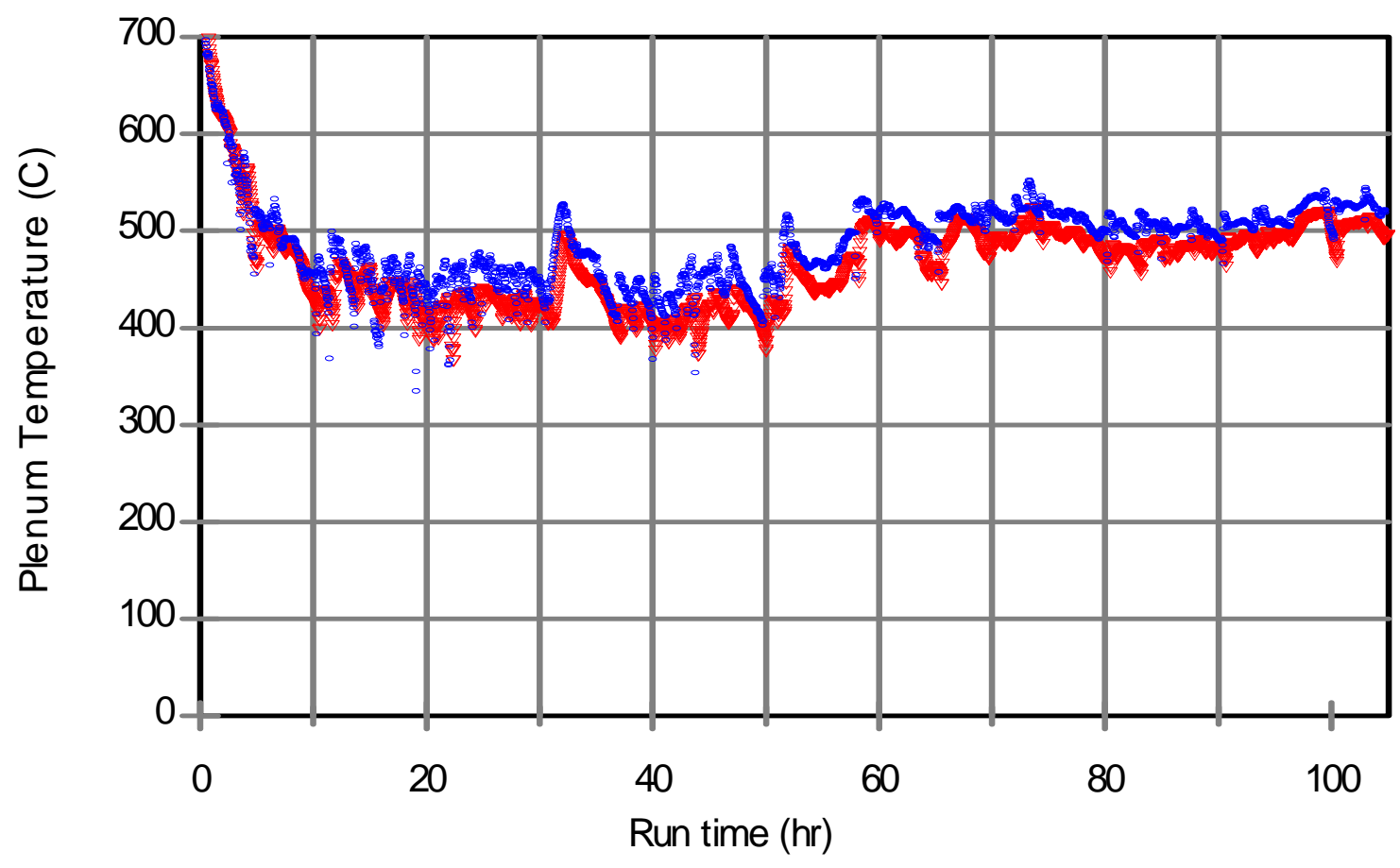

- 17" from top, Thermowell

- 17 " from top, Exposed

Figure 3.3.a. Plenum temperatures (hourly averages) during DM100 test with HLW-Bi-F3 glass composition. 


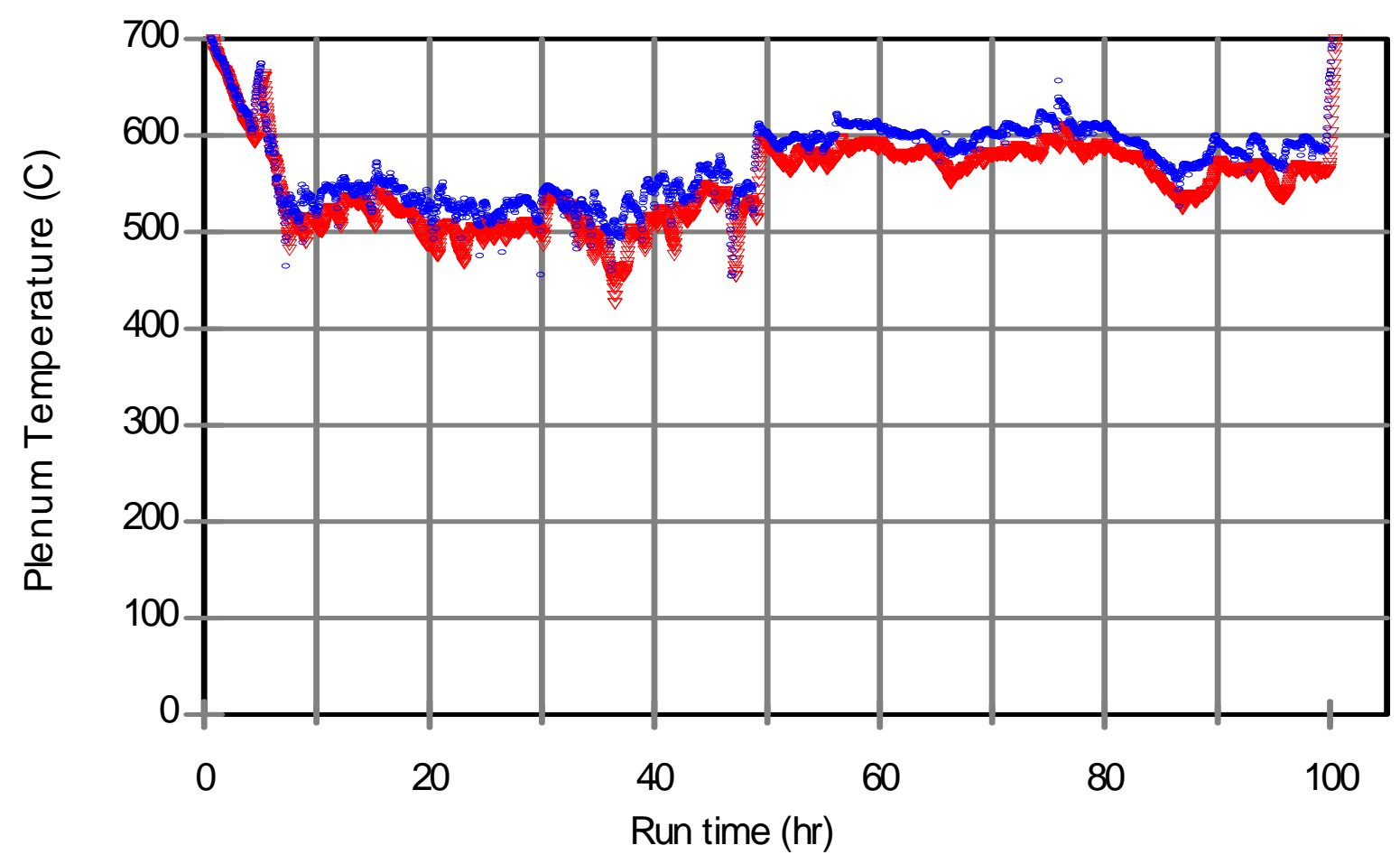

- 17" from top, Thermowell

- $\quad 17$ " from top, Exposed

Figure 3.3.b. Plenum temperatures (hourly averages) during DM100 test with HLW-Bi-F9 glass composition. 
ORP-56288 Rev. 0

The Catholic University of America

Vitreous State Laboratory

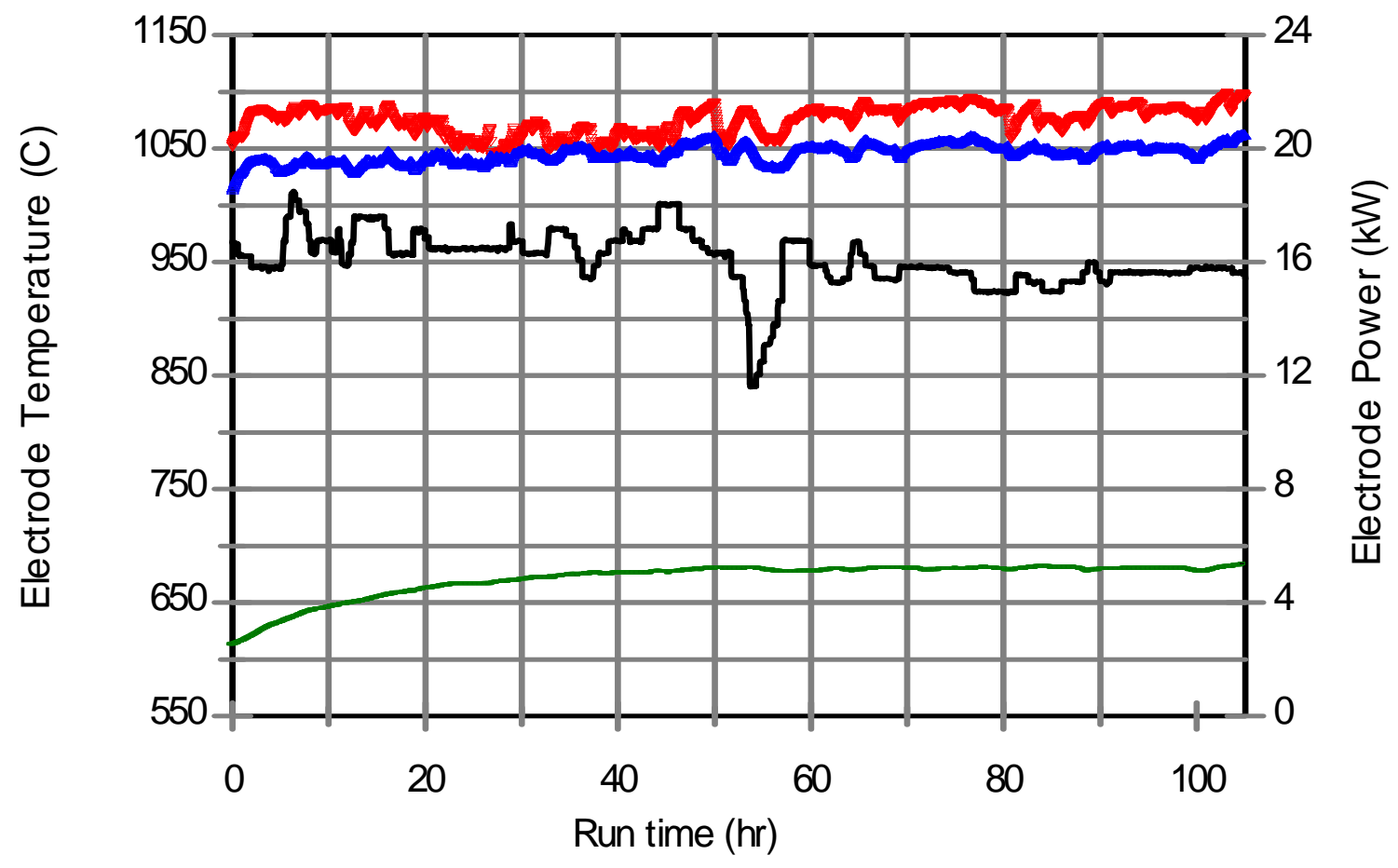

Figure 3.4.a. Electrode temperatures and power (hourly averages) during DM100 test with HLW-Bi-F3 glass composition. 


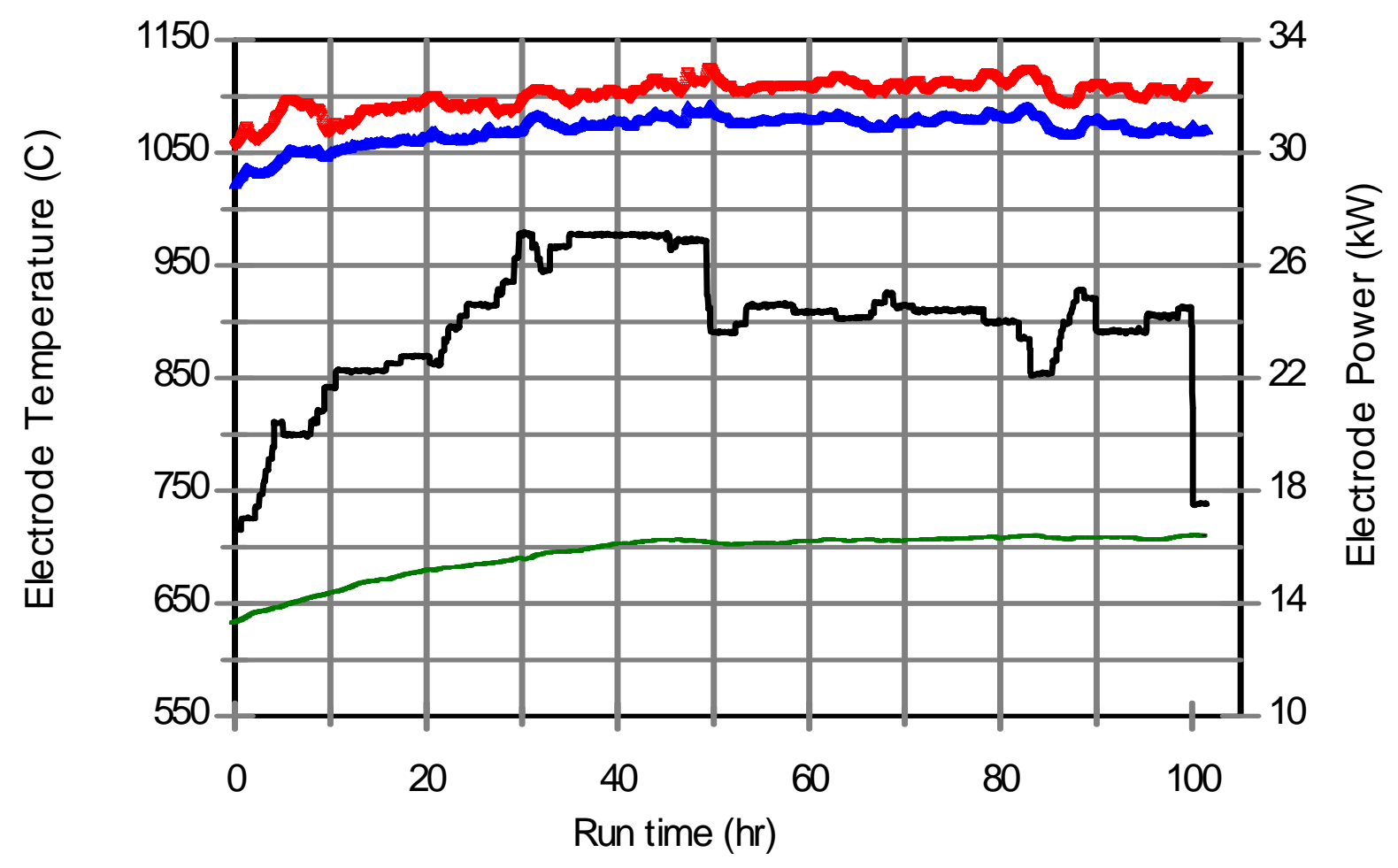
- Upper
- Lower
- Bottom
Power

Figure 3.4.b. Electrode temperatures and power (hourly averages) during DM100 test with HLW-Bi-F9 glass composition. 


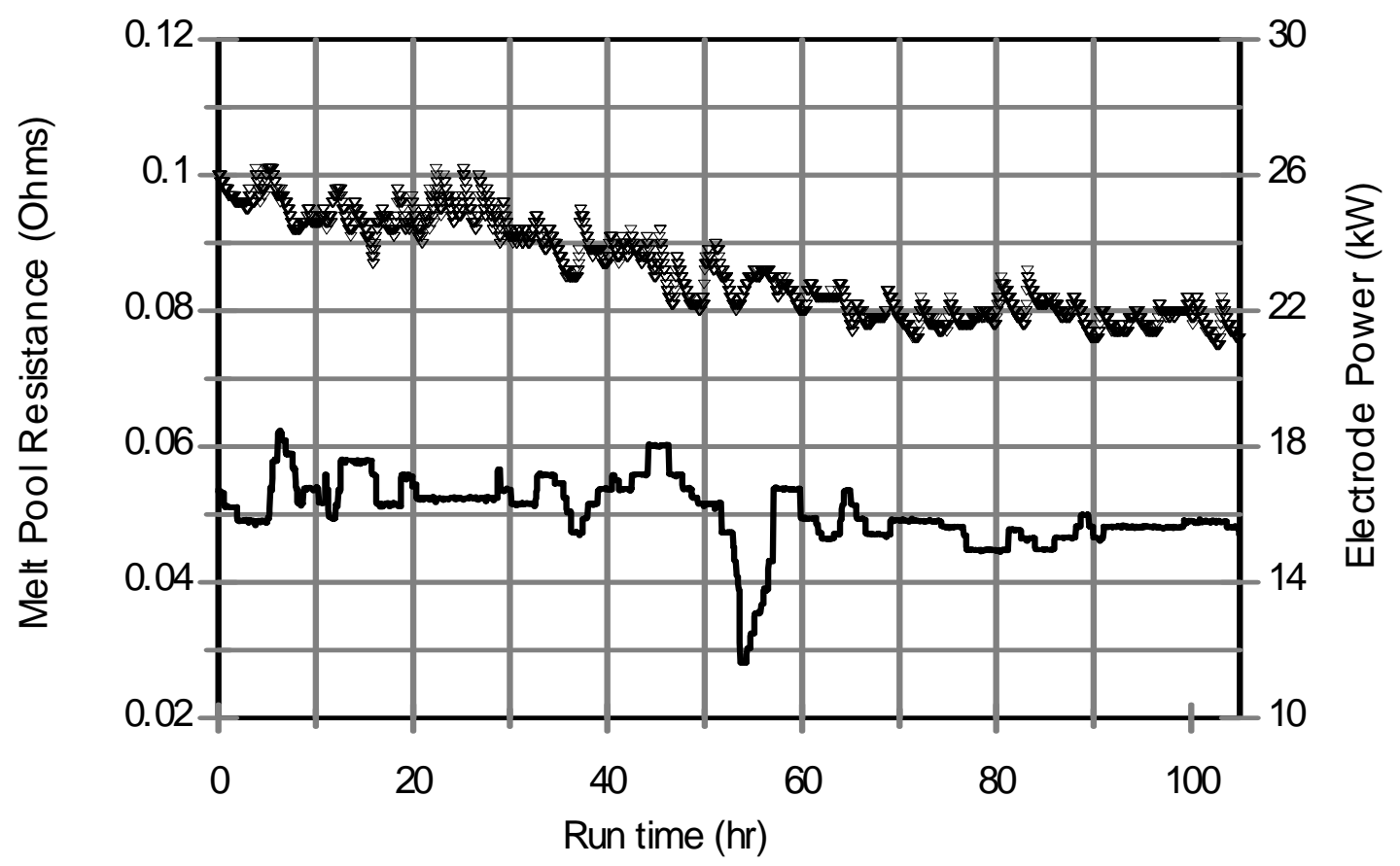

Figure 3.5.a. Melt pool resistance and total electrode power during DM100 test with HLW-Bi-F3 glass composition. 


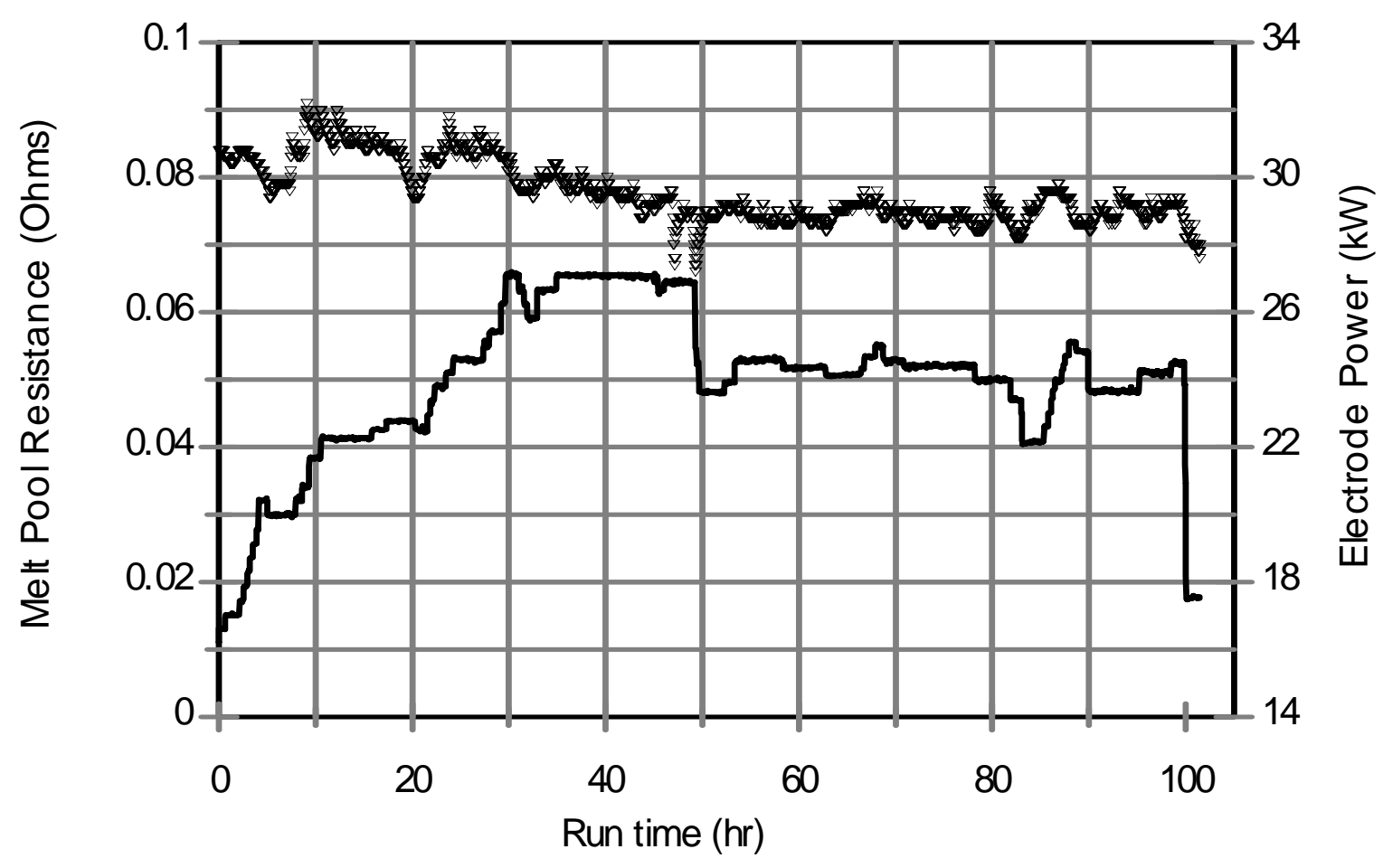

Figure 3.5.b. Melt pool resistance and total electrode power during DM100 test with HLW-Bi-F9 glass composition. 


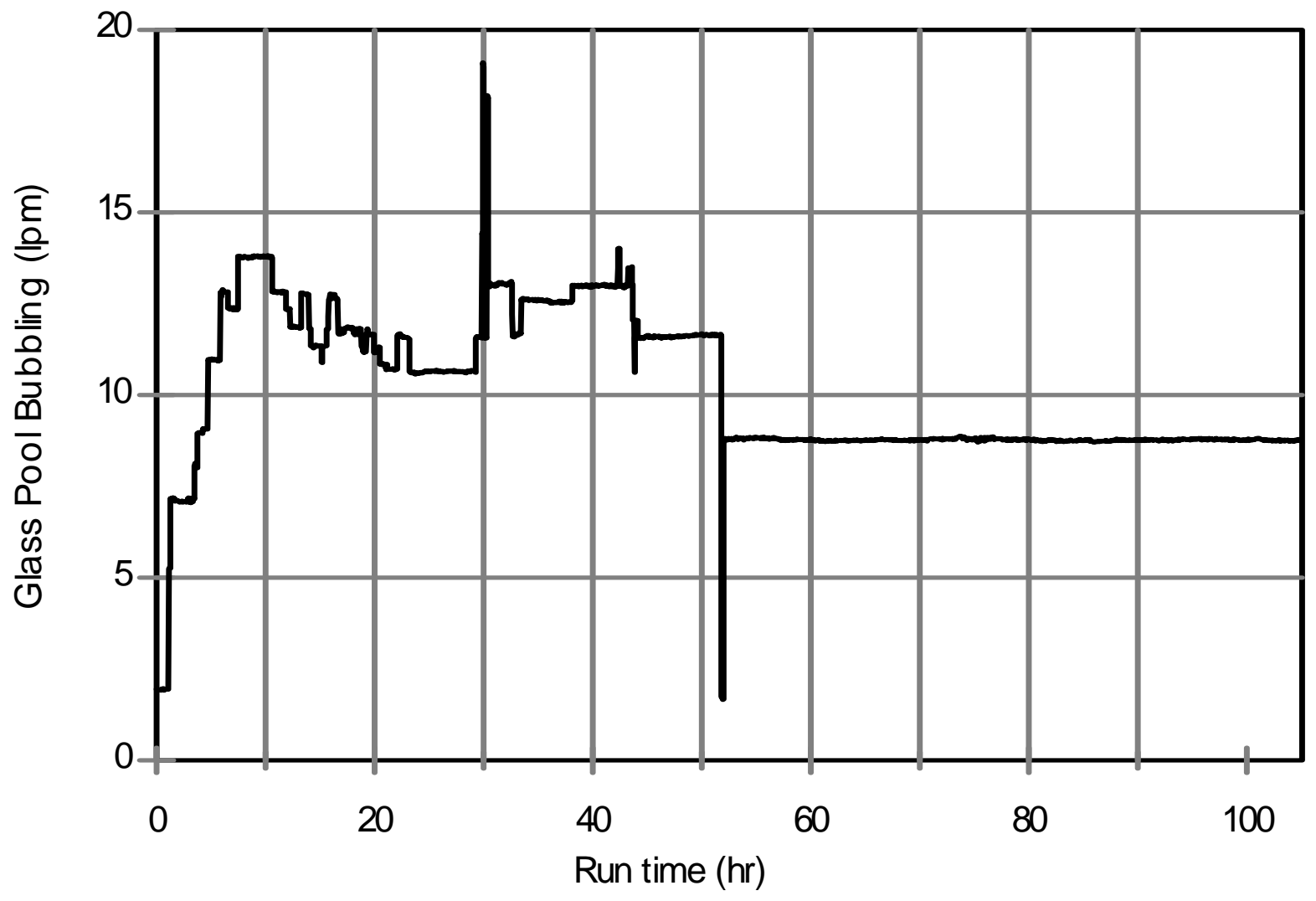

Figure 3.6.a. Melt pool bubbling during DM100 test with HLW-Bi-F3 glass composition. 


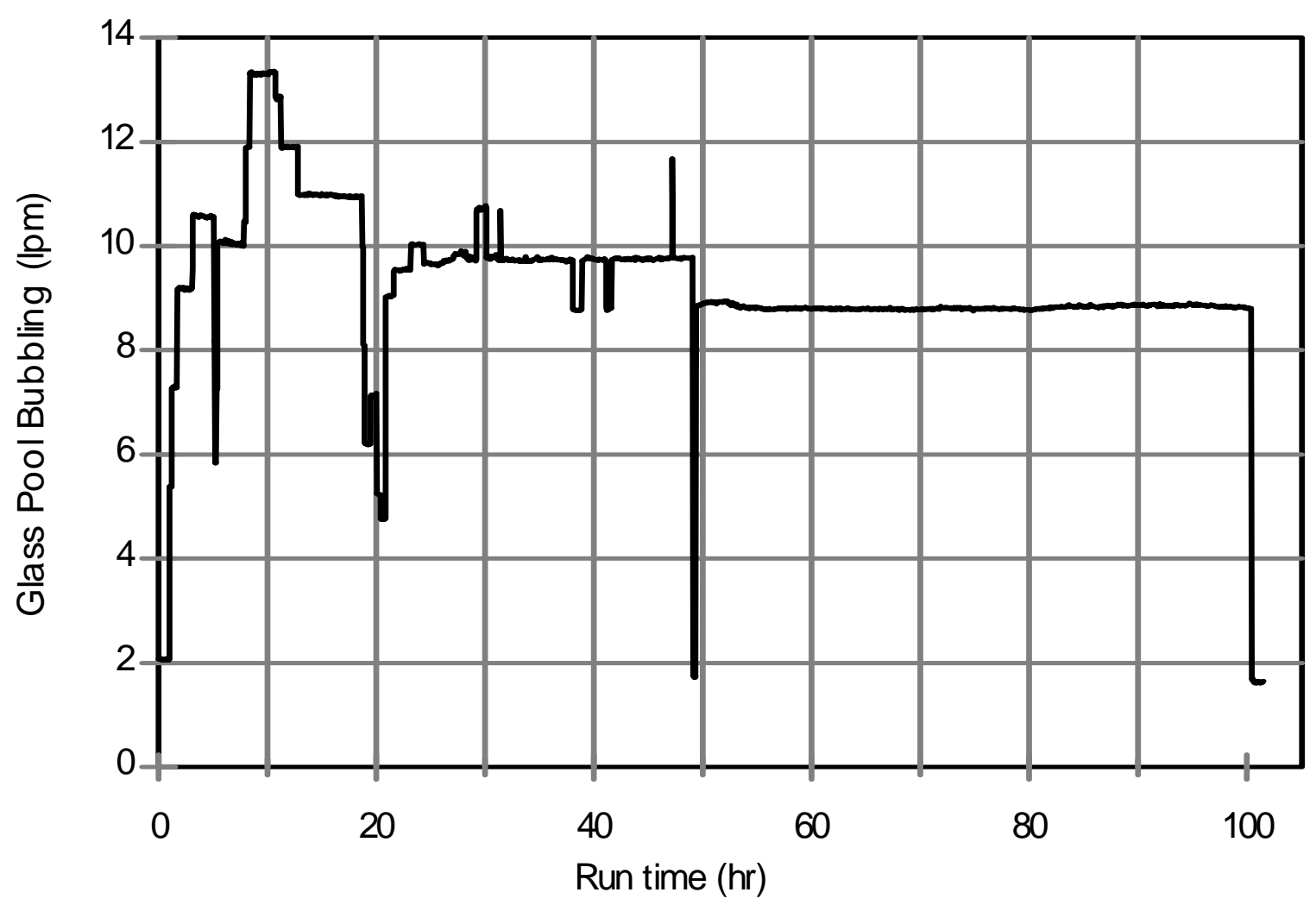

Figure 3.6.b. Melt pool bubbling during DM100 test with HLW-Bi-F9 glass composition. 

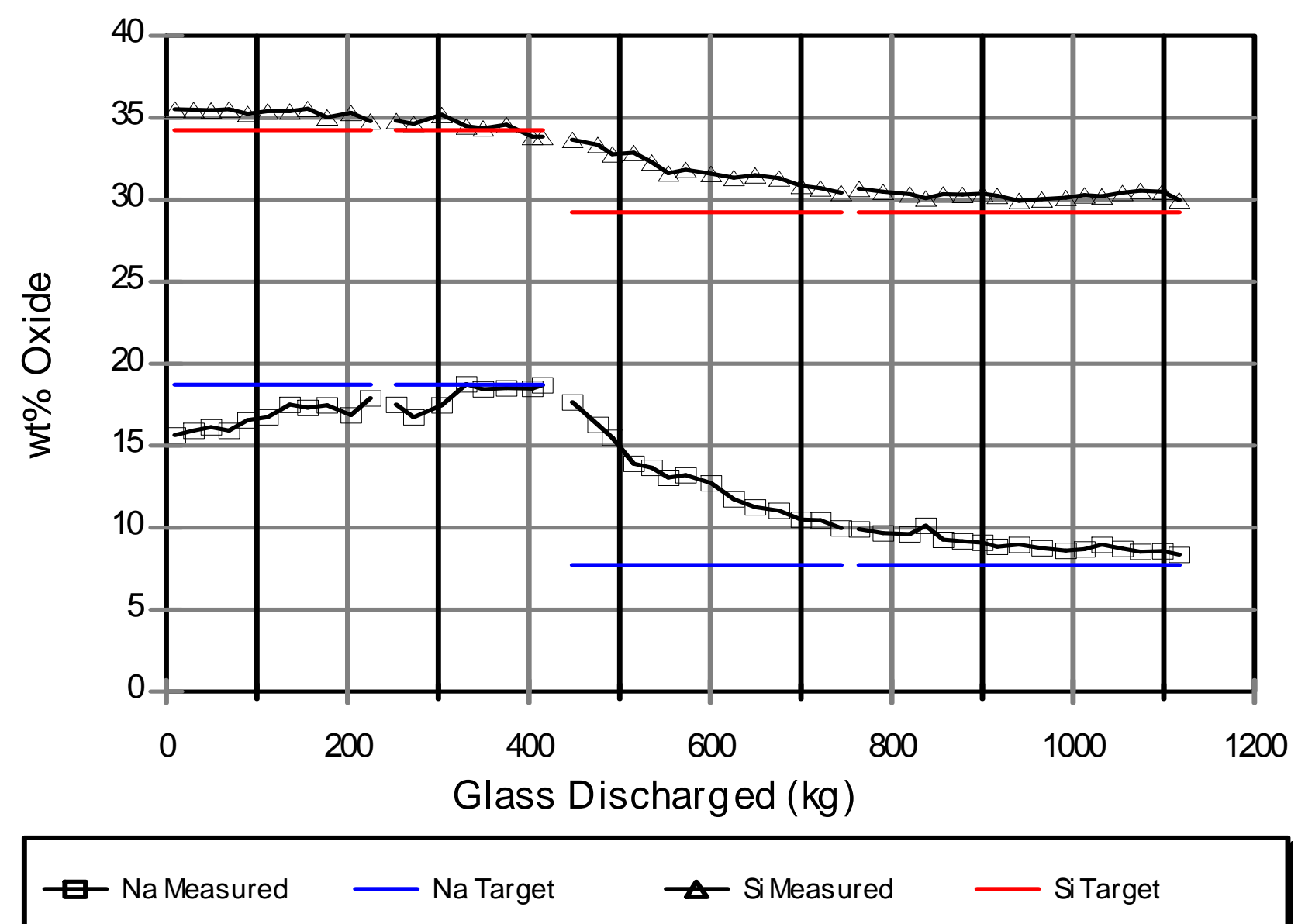

Figure 4.1. DM100 product and target glass compositions determined by XRF. 
ORP-56288 Rev. 0

The Catholic University of America

Vitreous State Laboratory

Melter Testing of New High Bismuth HLW Formulations

Final Report, VSL-13R2770-1, Rev. 0
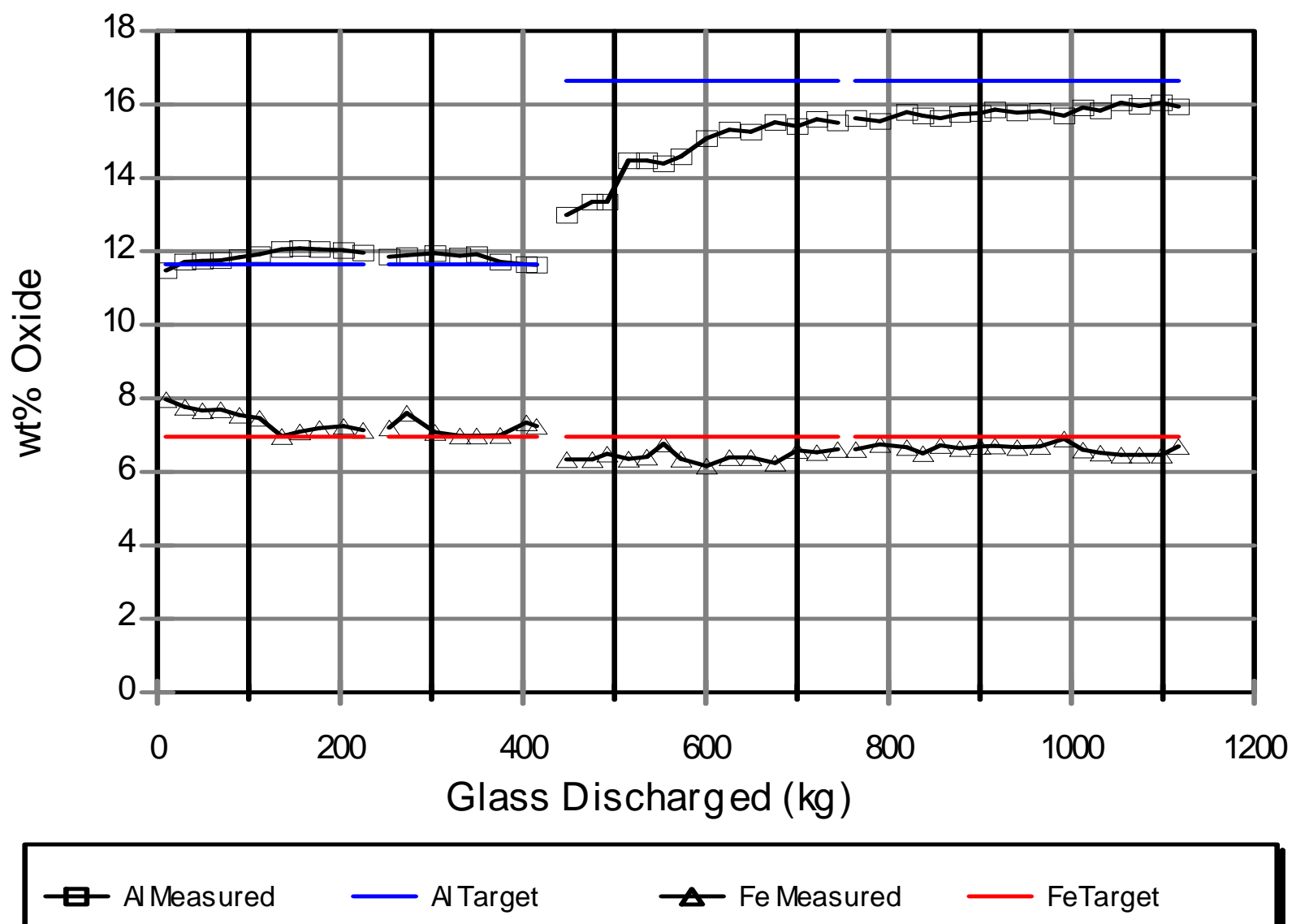

Figure 4.2. DM100 product and target glass compositions determined by XRF. 
ORP-56288 Rev. 0

The Catholic University of America

Vitreous State Laboratory

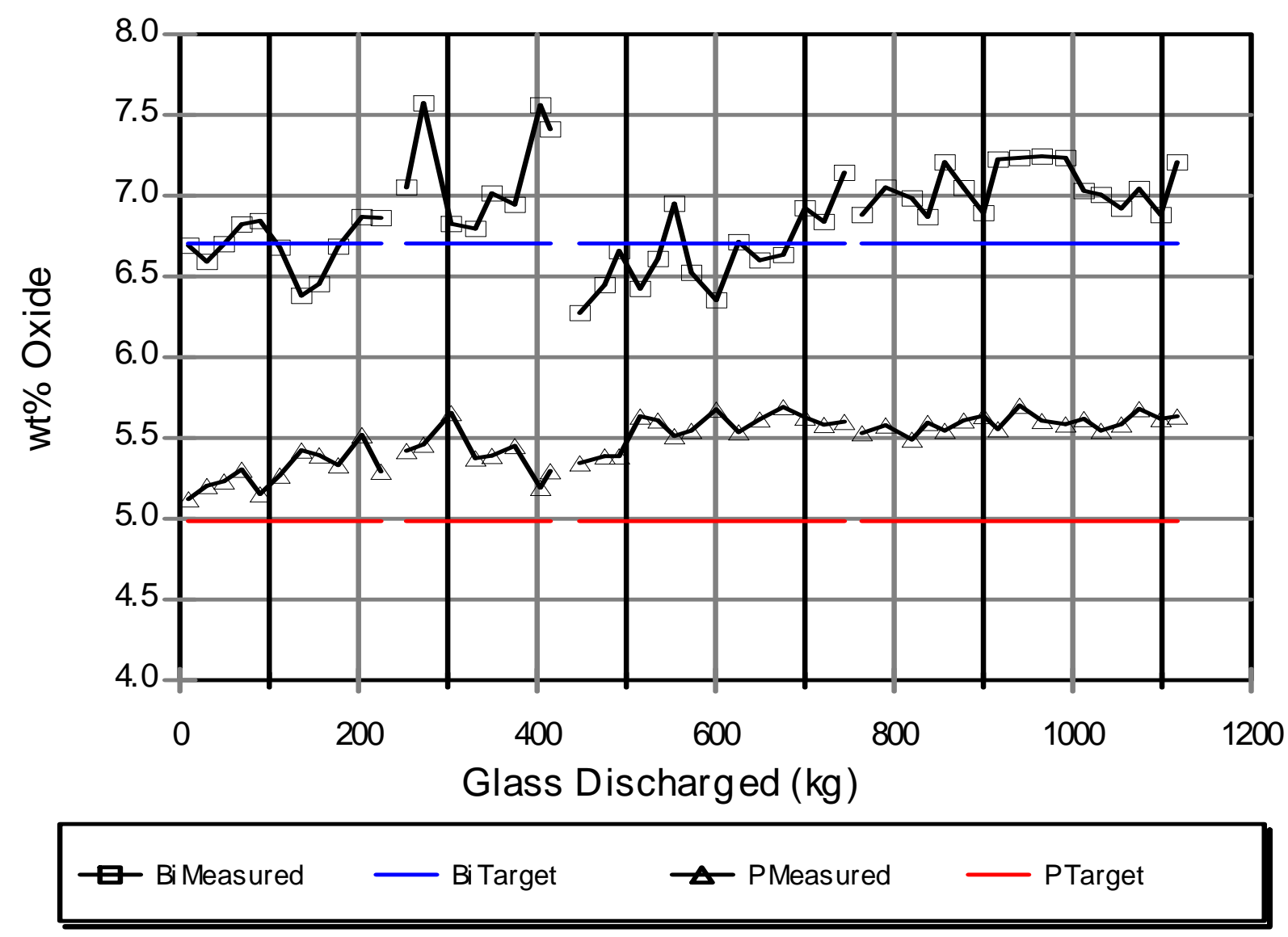

Figure 4.3. DM100 product and target glass compositions determined by XRF. 
ORP-56288 Rev. 0

The Catholic University of America

Vitreous State Laboratory

Melter Testing of New High Bismuth HLW Formulations

Final Report, VSL-13R2770-1, Rev. 0

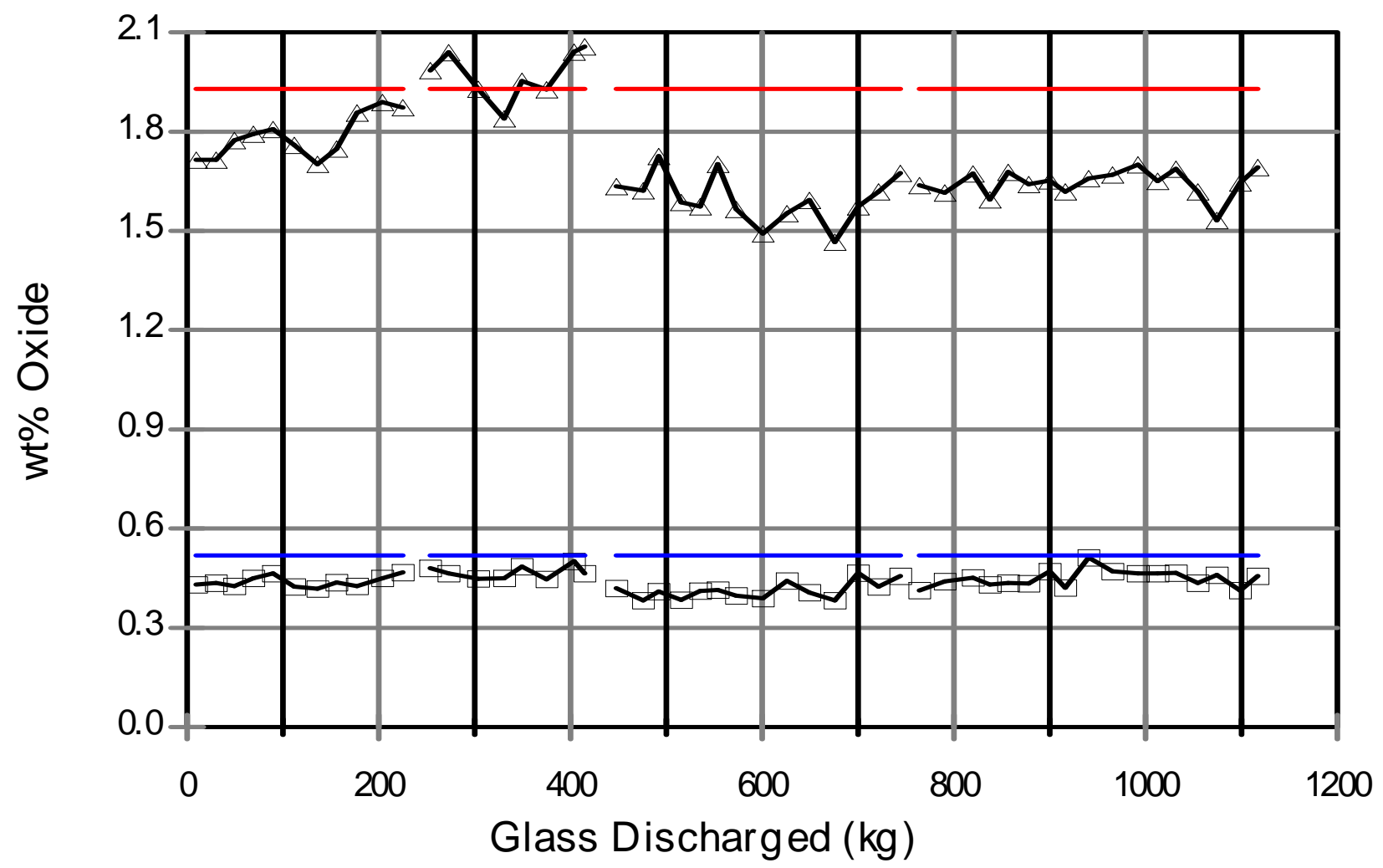

$\boldsymbol{\square}$ Cr Measured $\quad$ Cr Target Ni Measured $\quad-$ Ni Target

Figure 4.4. DM100 product and target glass compositions determined by XRF. 
ORP-56288 Rev. 0

The Catholic University of America

Vitreous State Laboratory
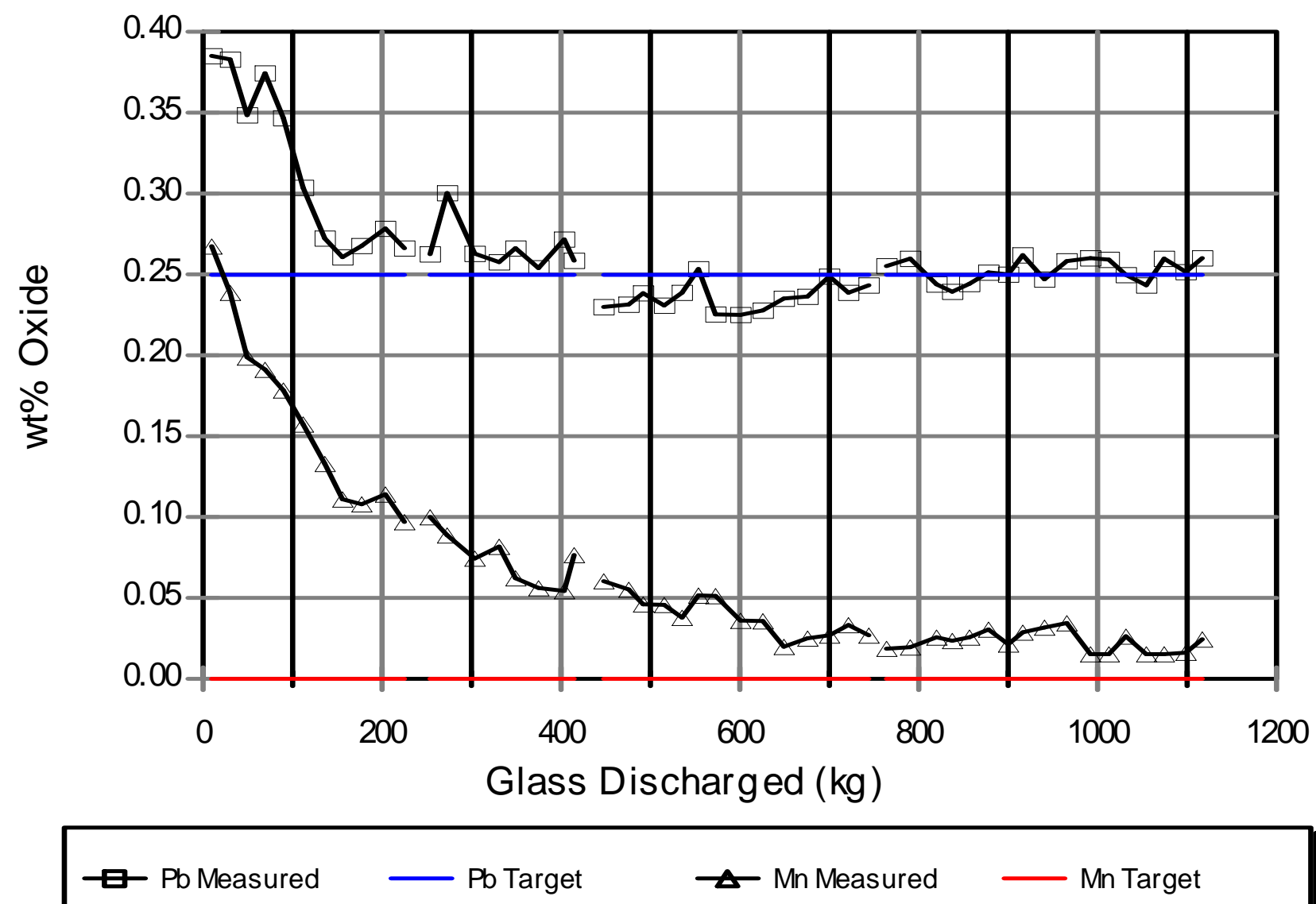

Figure 4.5. DM100 product and target glass compositions determined by XRF. 
ORP-56288 Rev. 0

The Catholic University of America

Vitreous State Laboratory

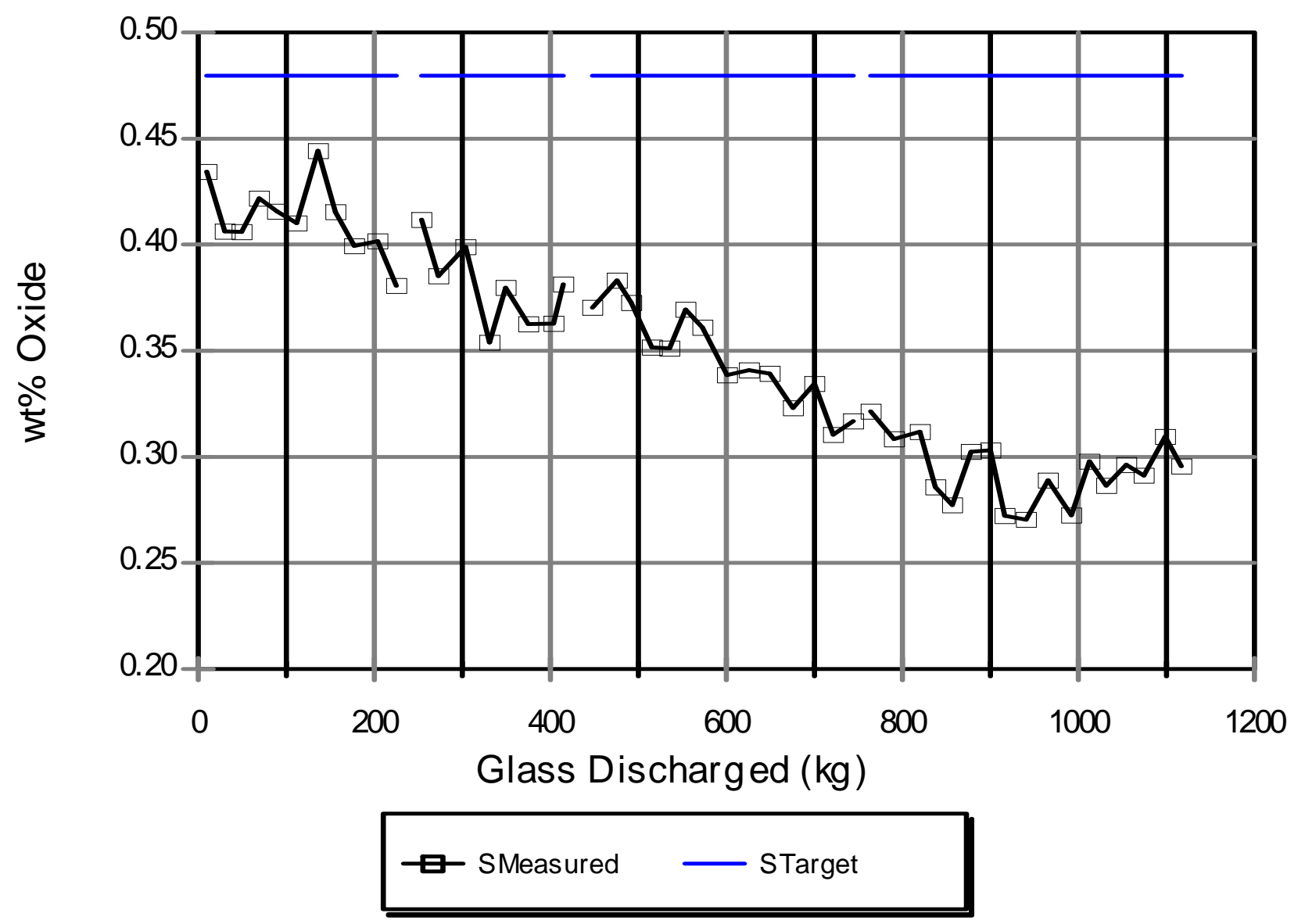

Figure 4.6. DM100 product and target glass compositions determined by XRF. 
ORP-56288 Rev. 0

The Catholic University of America

Melter Testing of New High Bismuth HLW Formulations

Vitreous State Laboratory

Final Report, VSL-13R2770-1, Rev. 0

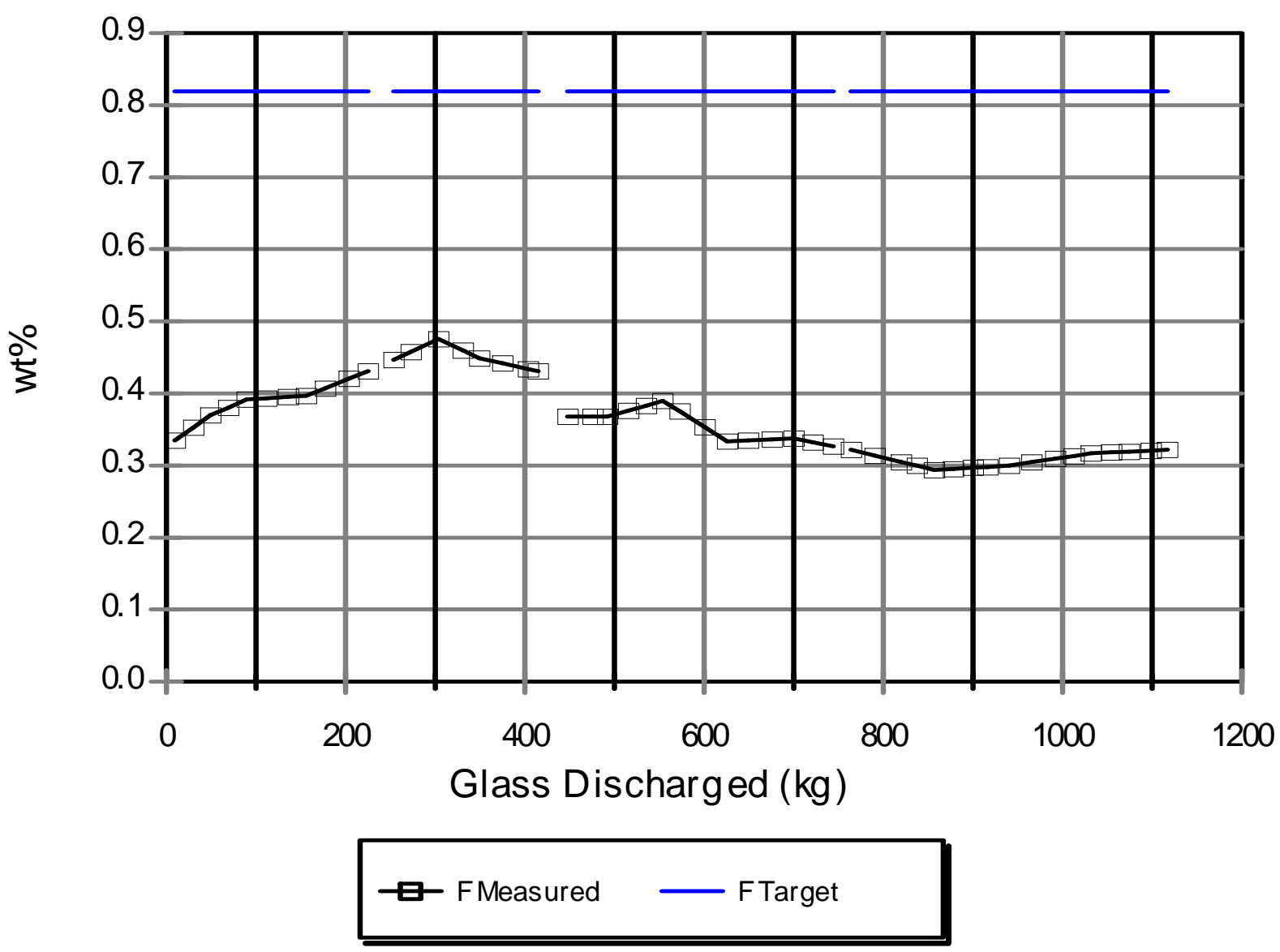

Figure 4.7. DM100 product and target glass compositions determined by XRF. 
The Catholic University of America Vitreous State Laboratory
Melter Testing of New High Bismuth HLW Formulations Final Report, VSL-13R2770-1, Rev. 0
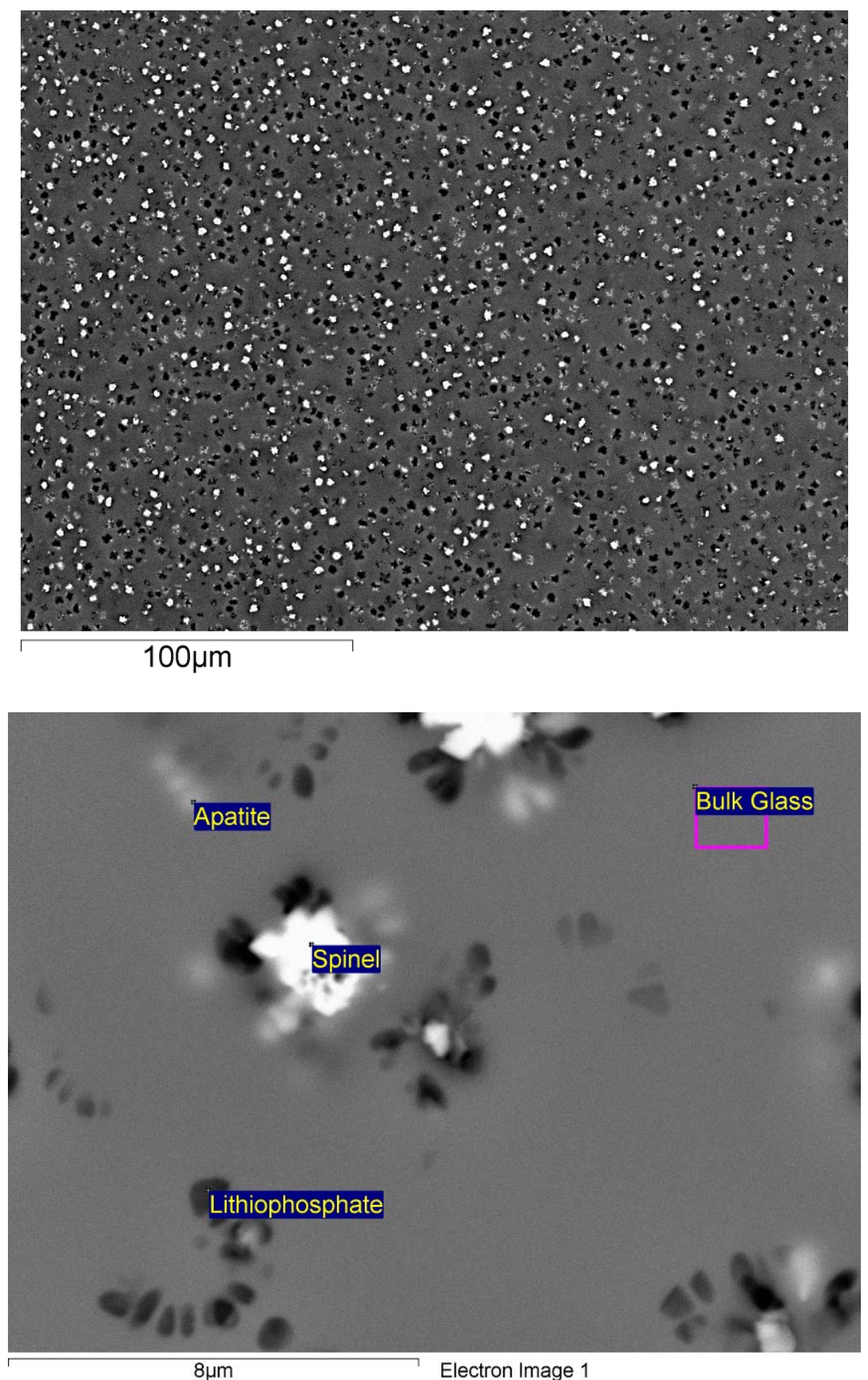

Figure 4.8. Typical areas in bulk of LBL-G-8A (HLW-Bi-F3 composition) at low (top) and high (bottom) magnification. 
The Catholic University of America

Vitreous State Laboratory
Melter Testing of New High Bismuth HLW Formulations Final Report, VSL-13R2770-1, Rev. 0

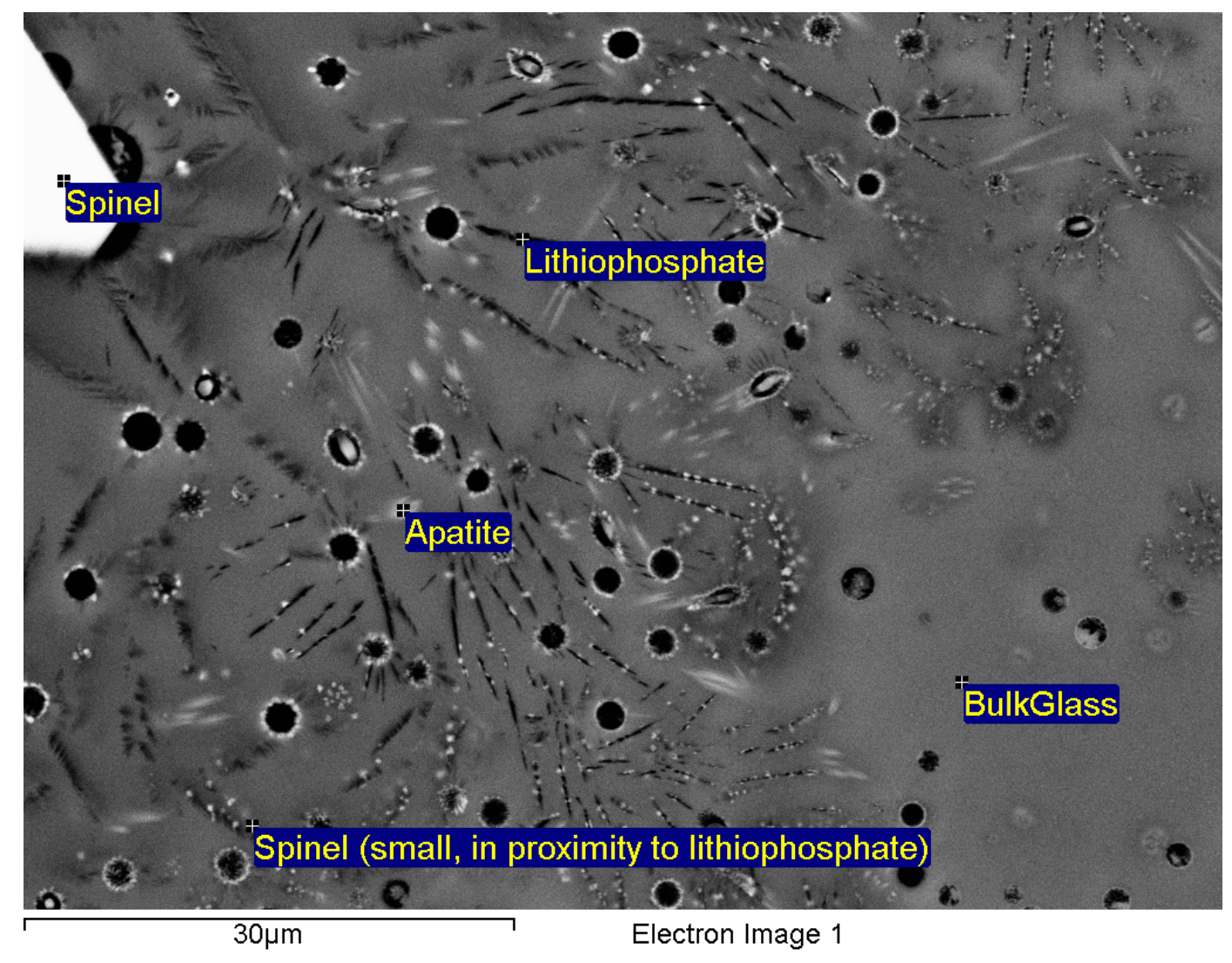

Figure 4.9.a. Region of incipient lithiophosphate growth in LBL-G-71A (HLW-Bi-F9 composition). Vesicles are circular dark regions, frequently surrounded by tiny crystals of other phases. 
The Catholic University of America Vitreous State Laboratory
Melter Testing of New High Bismuth HLW Formulations Final Report, VSL-13R2770-1, Rev. 0

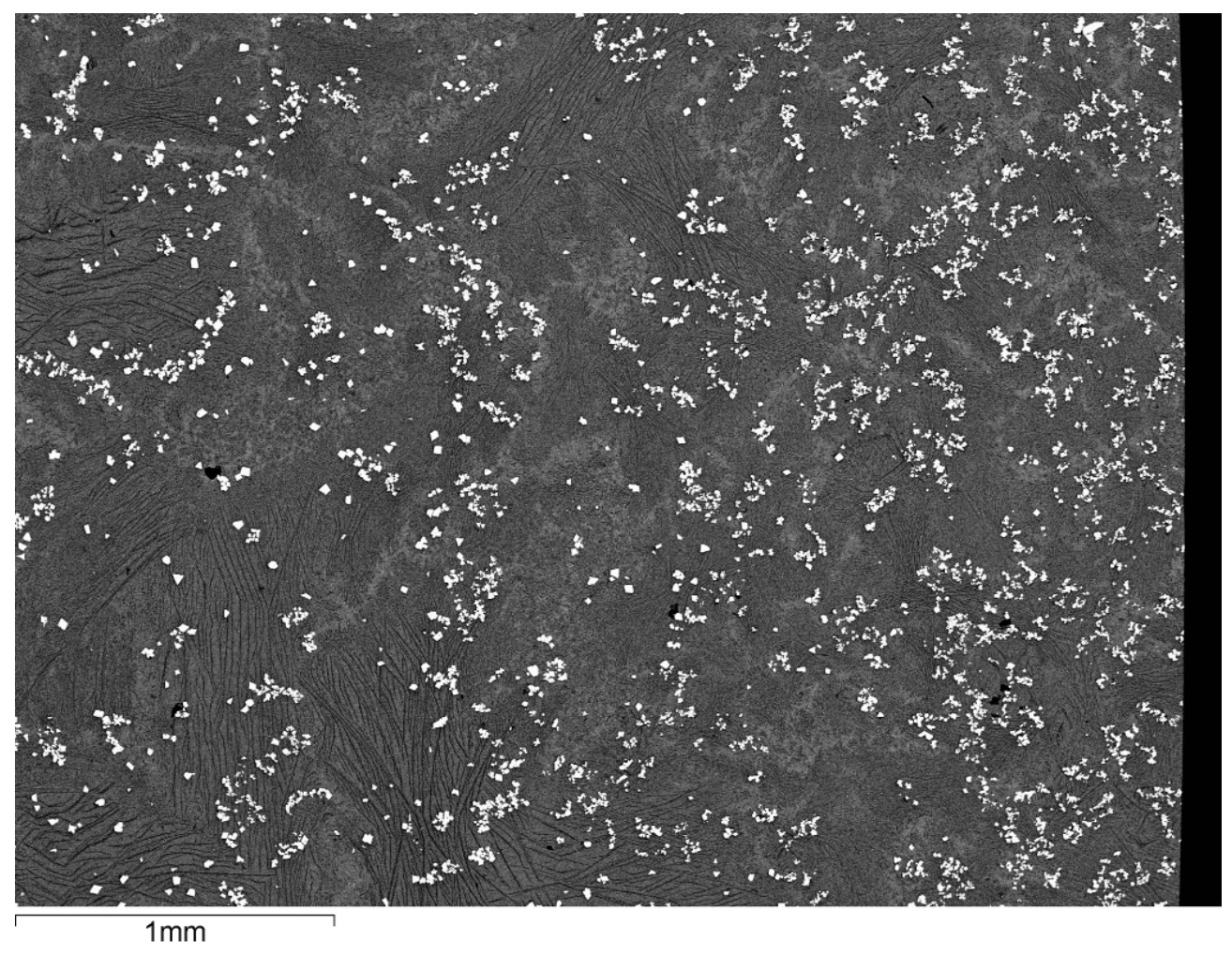

Figure 4.9.b. Large area view of LBL-G-71A (HLW-Bi-F9 composition) near bottom of crucible (to the right) showing settling of large spinels. 
ORP-56288 Rev. 0

The Catholic University of America

Melter Testing of New High Bismuth HLW Formulations

Vitreous State Laboratory

Final Report, VSL-13R2770-1, Rev. 0

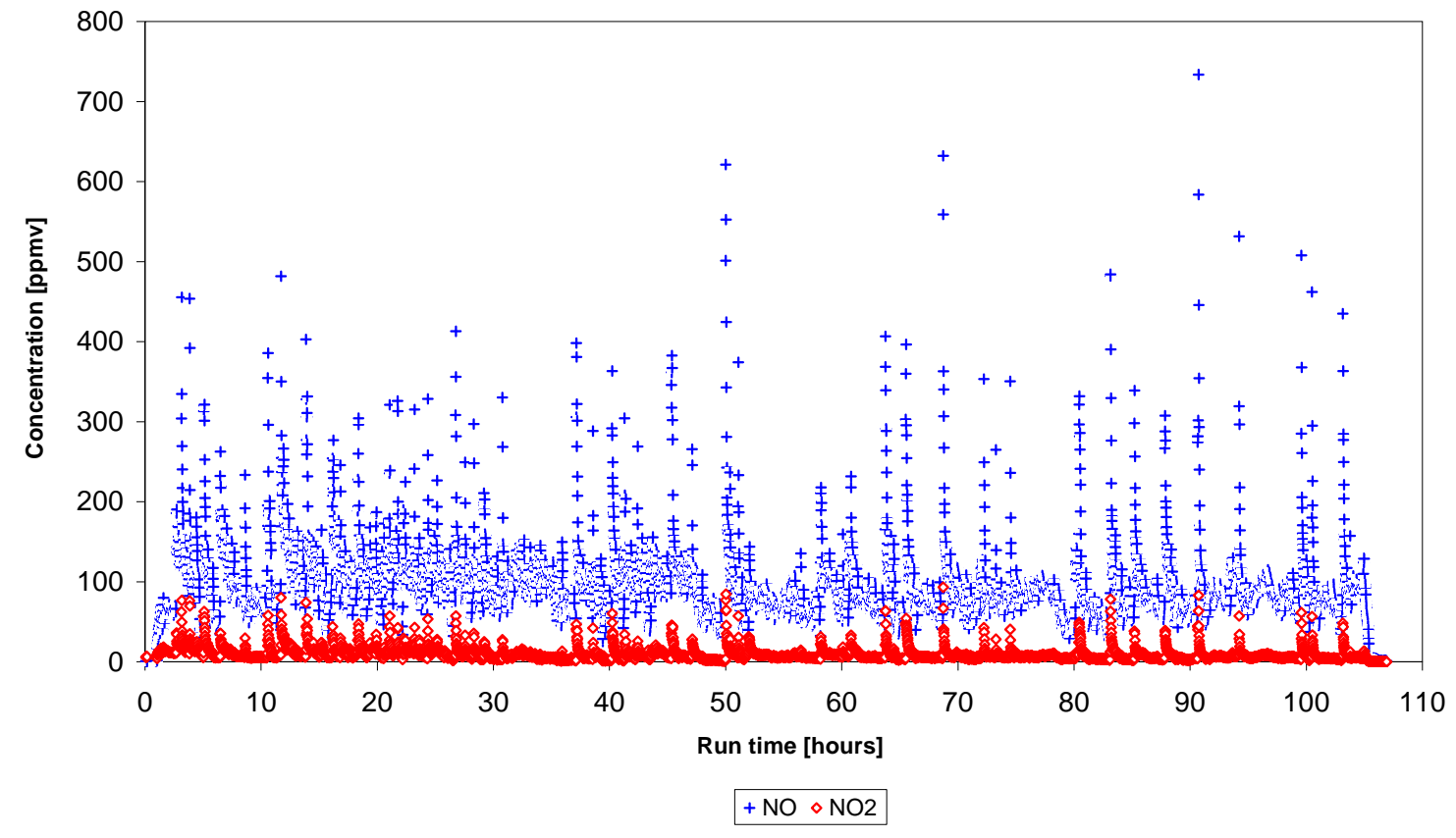

Figure 5.1. FTIR monitored nitrogen oxide emissions during tests processing the HLW-Bi-F3 composition. 
ORP-56288 Rev. 0

The Catholic University of America

Melter Testing of New High Bismuth HLW Formulations

Vitreous State Laboratory

Final Report, VSL-13R2770-1, Rev. 0

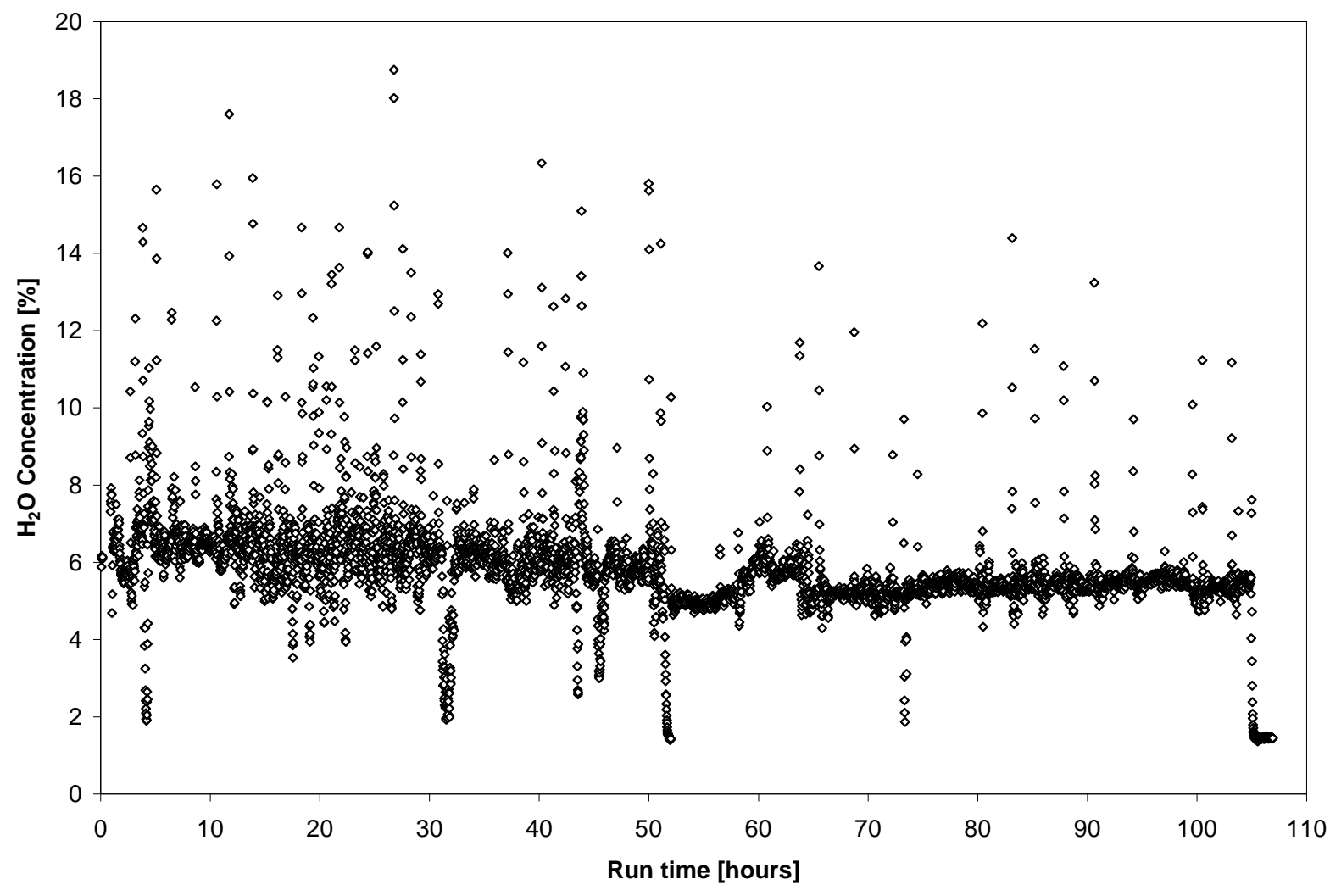

Figure 5.2. FTIR monitored water emissions during tests processing the HLW-Bi-F3 composition. 


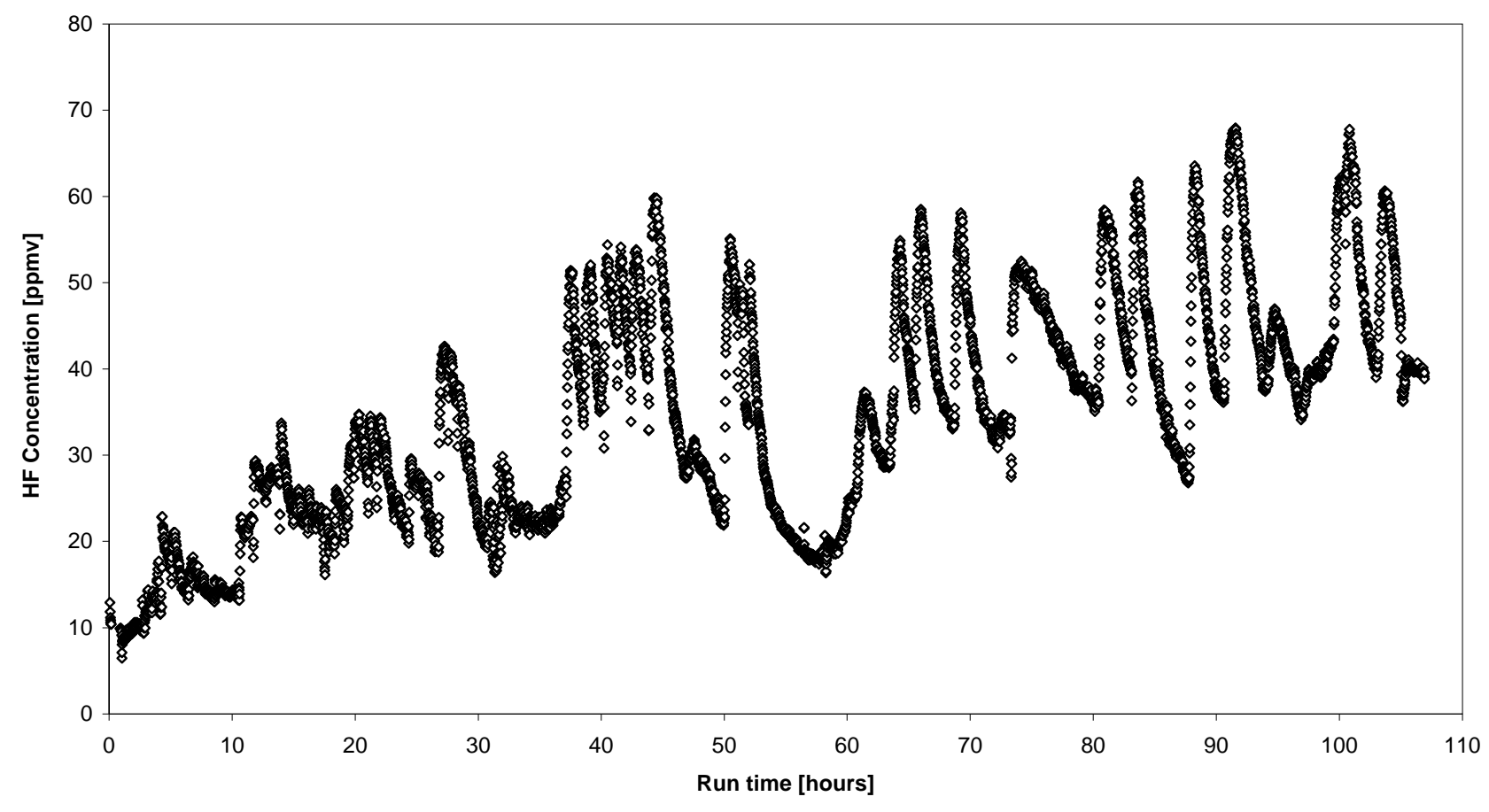

Figure 5.3. FTIR monitored hydrogen fluoride emissions during tests processing the HLW-Bi-F3 composition. 
ORP-56288 Rev. 0

The Catholic University of America

Melter Testing of New High Bismuth HLW Formulations

Vitreous State Laboratory

Final Report, VSL-13R2770-1, Rev. 0

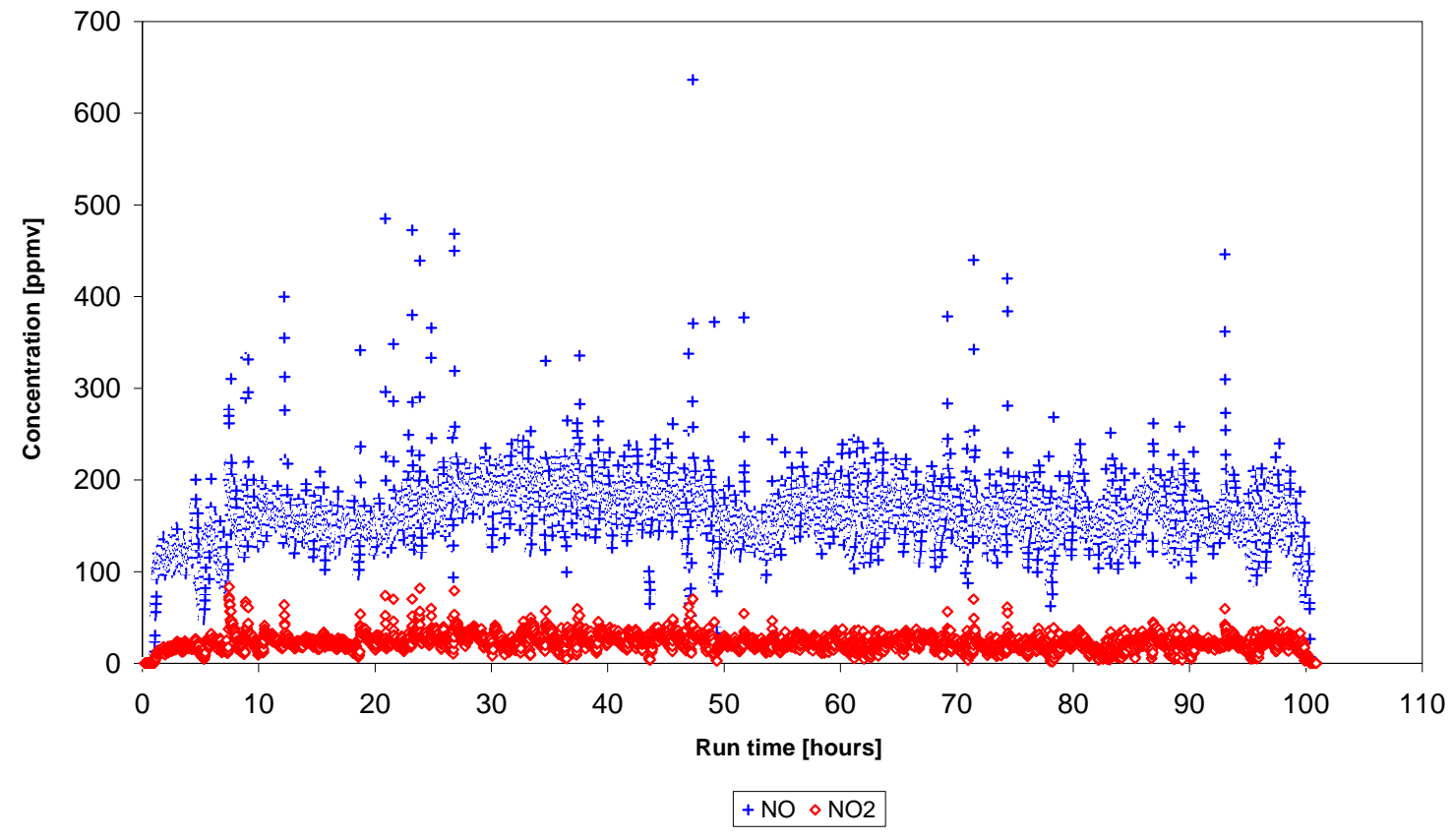

Figure 5.4. FTIR monitored nitrogen oxide emissions during tests processing the HLW-Bi-F9 composition. 
The Catholic University of America

Vitreous State Laboratory
Melter Testing of New High Bismuth HLW Formulations Final Report, VSL-13R2770-1, Rev. 0

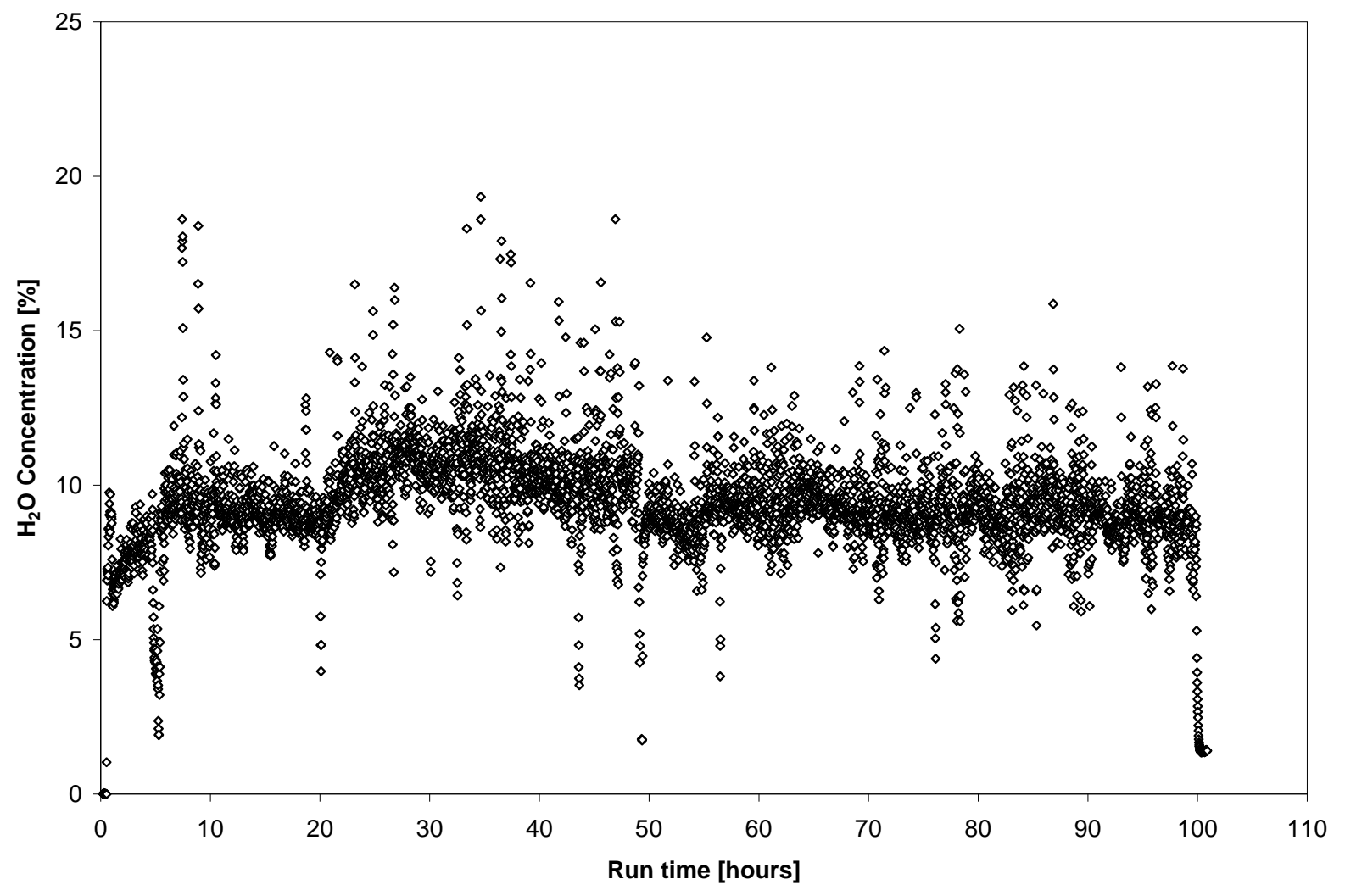

Figure 5.5. FTIR monitored water emissions during tests processing the HLW-Bi-F9 composition. 
ORP-56288 Rev. 0

The Catholic University of America

Melter Testing of New High Bismuth HLW Formulations

Vitreous State Laboratory

Final Report, VSL-13R2770-1, Rev. 0

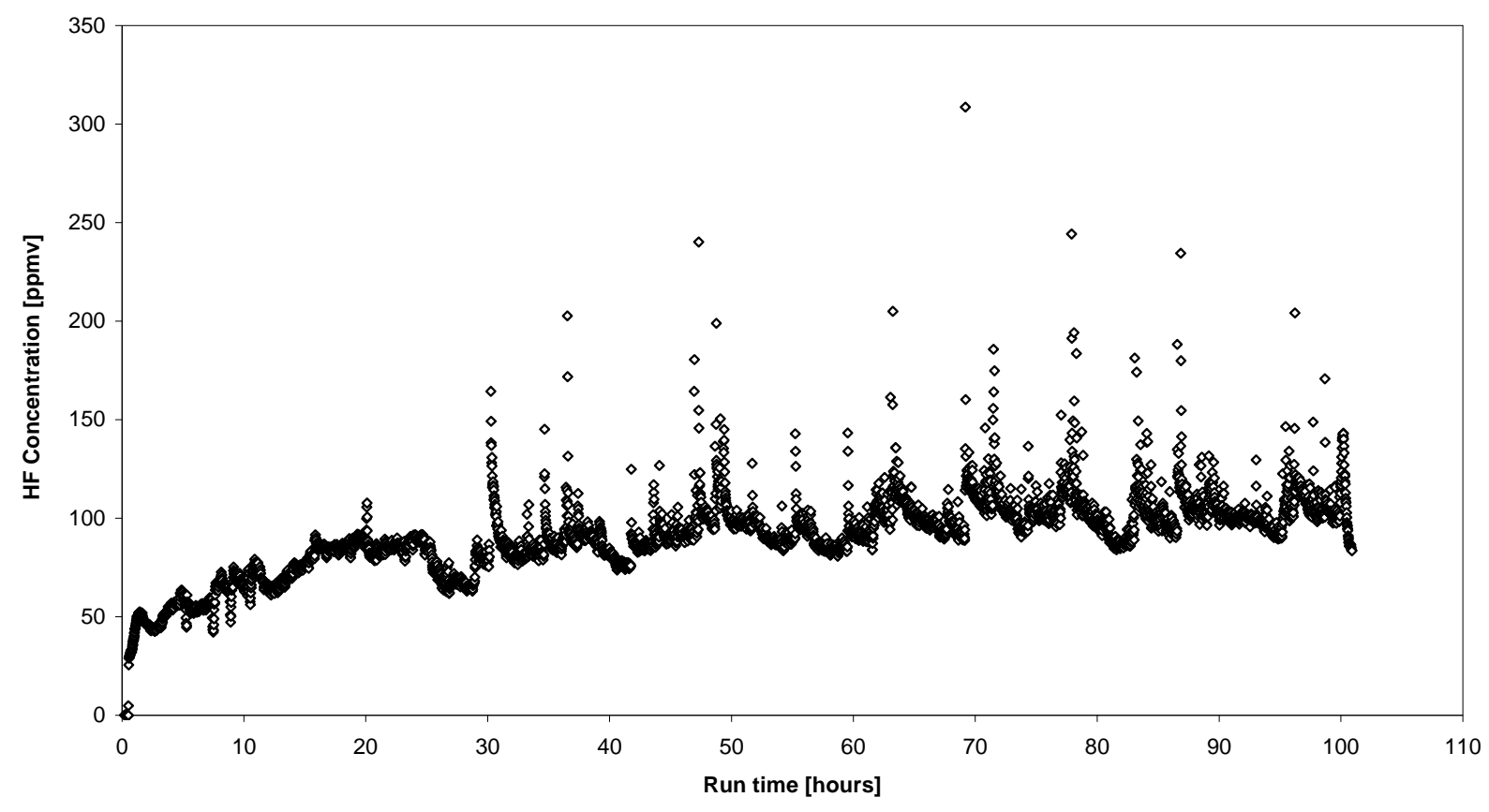

Figure 5.6. FTIR monitored hydrogen fluoride emissions during tests processing the HLW-Bi-F9 composition. 